SURFACE-WATER-QUALITY ASSESSMENT OF THE UPPER ILLINOIS RIVER BASIN IN ILLINOIS, INDIANA, AND WISCONSIN-RESULTS OF INVESTIGATIONS THROUGH APRIL 1992

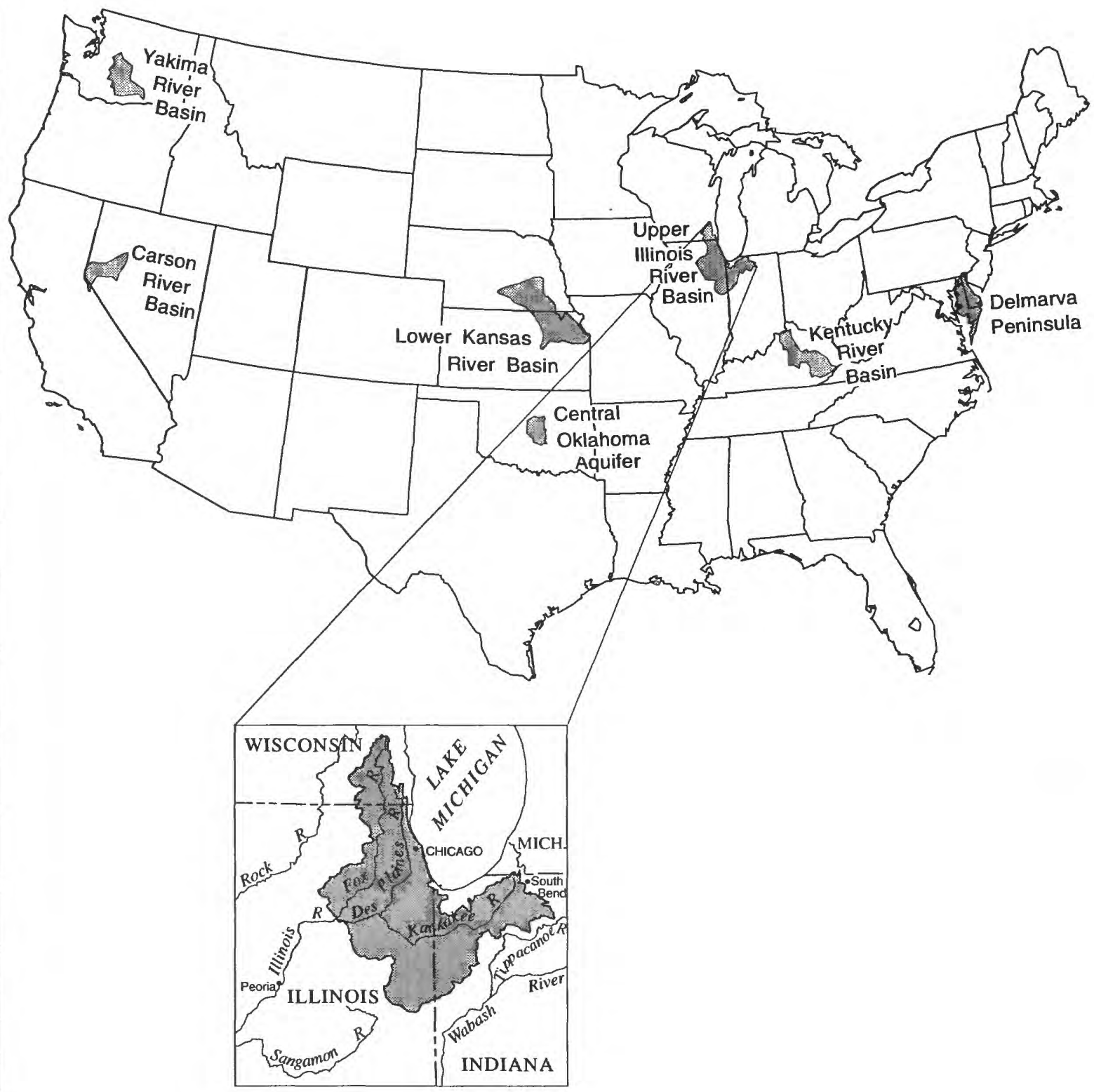

U.S. GEOLOGICAL SURVEY

Water-Resources Investigations Report 96-4223 


\section{SURFACE-WATER-QUALITY ASSESSMENT OF THE UPPER ILLINOIS RIVER BASIN IN ILLINOIS, INDIANA, AND WISCONSIN-RESULTS OF INVESTIGATIONS THROUGH APRIL 1992}

by Arthur R. Schmidt and Stephen F. Blanchard

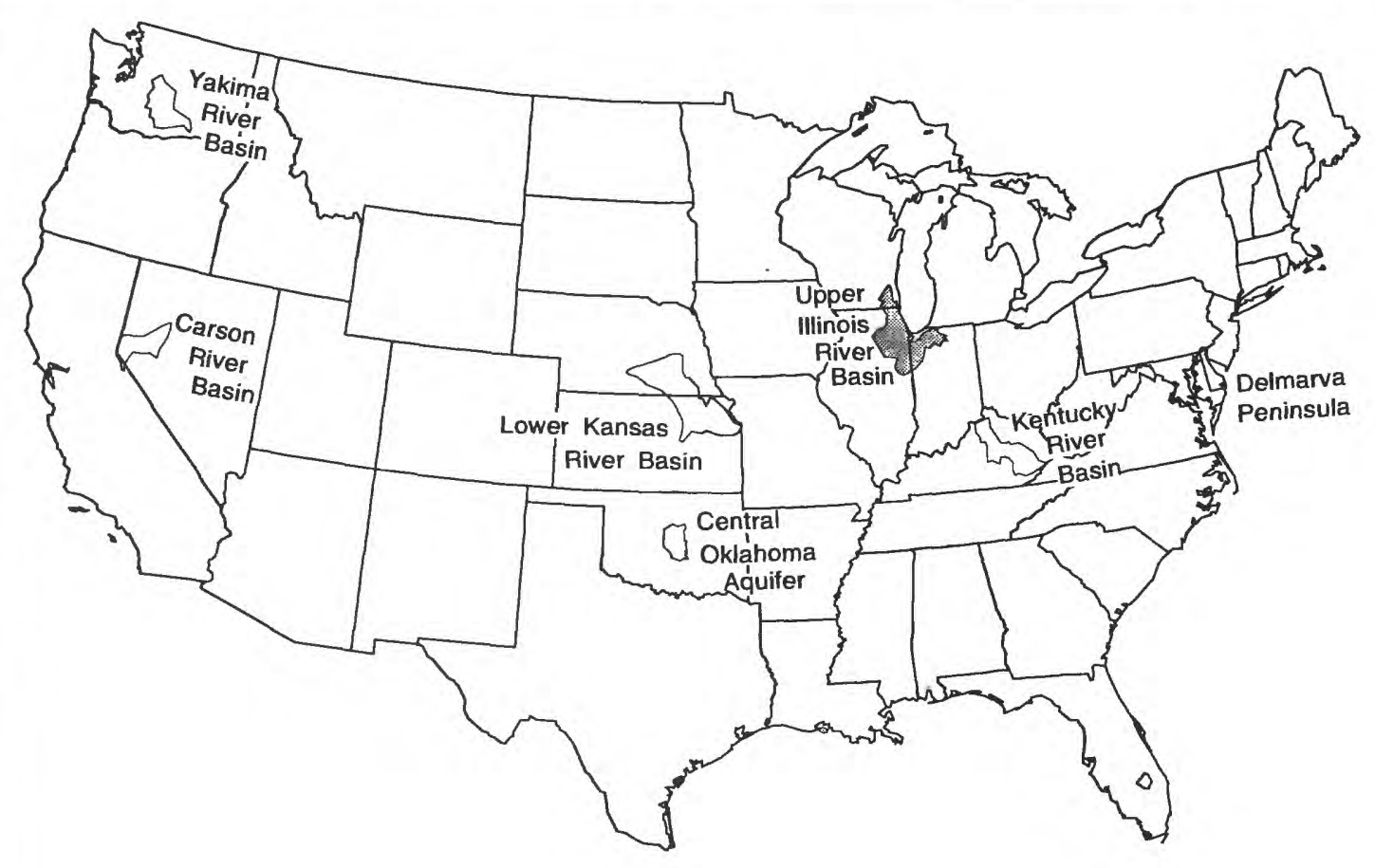

\section{U.S. GEOLOGICAL SURVEY}

Water-Resources Investigations Report 96-4223

Urbana, Illinois 


\section{U.S. DEPARTMENT OF THE INTERIOR \\ BRUCE BABBITT, Secretary}

U.S. GEOLOGICAL SURVEY

Gordon P. Eaton, Director

The use of firm, trade, and brand names in this report is for identification purposes only and does not constitute endorsement by the U.S. Geological Survey.

For additional information write to:

District Chief

U.S. Geological Survey

221 N. Broadway

Urbana, IL 61801
Copies of this report can be purchased from:

U.S. Geological Survey

Branch of Information Services

Box 25286

Federal Center

Denver, CO 80225 


\section{FOREWORD}

The mission of the U.S. Geological Survey

(USGS) is to assess the quantity and quality of the earth resources of the Nation and to provide information that will assist resource managers and policymakers at Federal, State, and local levels in making sound decisions. Assessment of water-quality conditions and trends is an important part of this overall mission.

One of the greatest challenges faced by waterresources scientists is acquiring reliable information that will guide the use and protection of the Nation's water resources. That challenge is being addressed by Federal, State, interstate, and local water-resource agencies and by many academic institutions. These organizations are collecting water-quality data for a host of purposes that include: compliance with permits and water-supply standards; development of remediation plans for specific contamination problems; operational decisions on industrial, wastewater, or watersupply facilities; and research on factors that affect water quality. An additional need for water-quality information is to provide a basis on which regionaland national-level policy decisions can be based. Wise decisions must be based on sound information. As a society we need to know whether certain types of water-quality problems are isolated or ubiquitous, whether there are significant differences in conditions among regions, whether the conditions are changing over time, and why these conditions change from place to place and over time. The information can be used to help determine the efficacy of existing waterquality policies and to help analysts determine the need for and likely consequences of new policies.

To address these needs, the U.S. Congress appropriated funds in 1986 for the USGS to begin a pilot program in seven project areas to develop and refine the National Water-Quality Assessment (NAWQA) Program. In 1991, the USGS began full implementation of the program. The NAWQA Program builds upon an existing base of water-quality studies of the USGS, as well as those of other Federal, State, and local agencies. The objectives of the NAWQA Program are to:

- Describe current water-quality conditions for a large part of the Nation's freshwater streams, rivers, and aquifers.
- Describe how water quality is changing over time.

- Improve understanding of the primary natural and human factors that affect water-quality conditions.

This information will help support the development and evaluation of management, regulatory, and monitoring decisions by other Federal, State, and local agencies to protect, use, and enhance water resources.

The goals of the NAWQA Program are being achieved through ongoing and proposed investigations of 60 of the Nation's most important river basins and aquifer systems, which are referred to as study units. These study units are distributed throughout the Nation and cover a diversity of hydrogeologic settings. More than two-thirds of the Nation's freshwater use occurs within the 60 study units and more than twothirds of the people served by public water-supply systems live within their boundaries.

National synthesis of data analysis, based on aggregation of comparable information obtained from the study units, is a major component of the program. This effort focuses on selected water-quality topics using nationally consistent information. Comparative studies will explain differences and similarities in observed water-quality conditions among study areas and will identify changes and trends and their causes. The first topics addressed by the national synthesis are pesticides, nutrients, volatile organic compounds, and aquatic biology. Discussions on these and other waterquality topics will be published in periodic summaries of the quality of the Nation's ground and surface water as the information becomes available.

This report is an element of the comprehensive body of information developed as part of the NAWQA Program. The program depends heavily on the advice, cooperation, and information from many Federal, State, interstate, Tribal, and local agencies and the public. The assistance and suggestions of all are greatly appreciated.

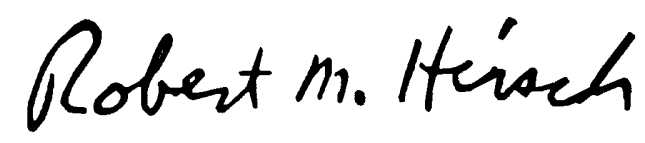

Robert M. Hirsch Chief Hydrologist 


\section{CONTENTS}

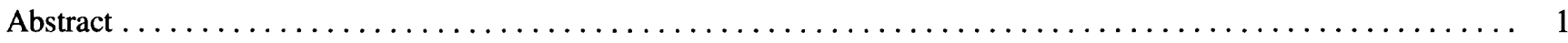

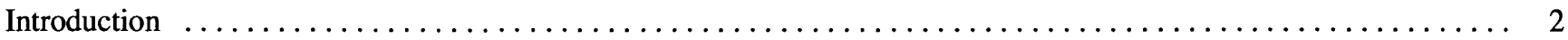

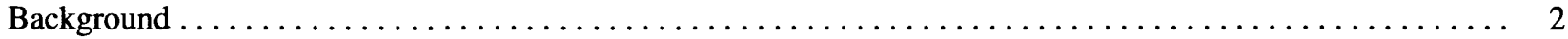

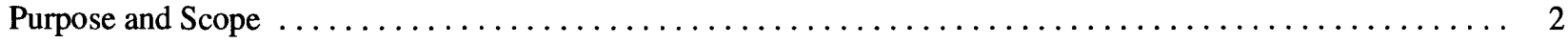

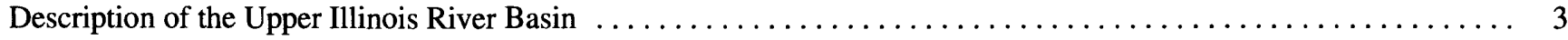

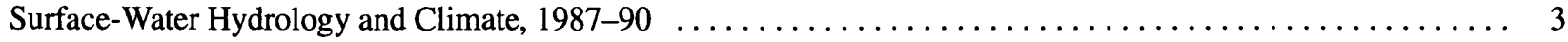

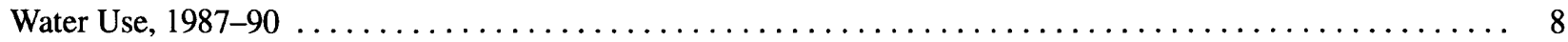

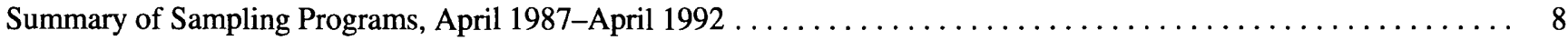

Water-Quality Conditions (1987-91) and Trends (1978-91) in the Upper Illinois River Basin ............. 12

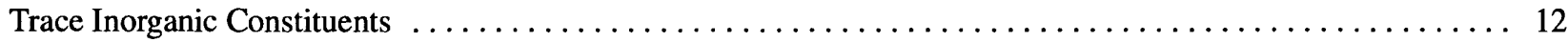

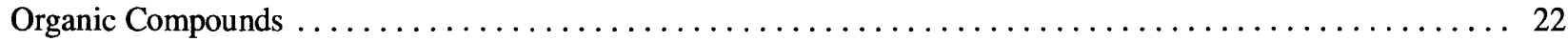

Nutrients, Dissolved Oxygen, and Fecal-Indicator Bacteria $\ldots \ldots \ldots \ldots \ldots \ldots \ldots \ldots \ldots \ldots \ldots \ldots \ldots 31$

Results of Studies and Implications for the National Water-Quality Assessment Program . . . . . . . . . . . 43

Availability and Suitability of Information on Municipal Wastewater-Treatment Practices for

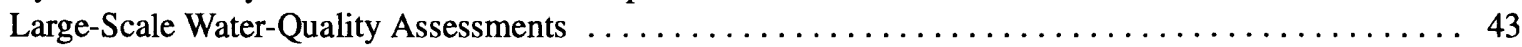

Evaluation of the Effects of Changes in Wastewater-Treatment Practices on Stream-Water Quality . . . . . . . 43

Fish-Community Composition and Structure as a Measure of Water-Quality Conditions $\ldots \ldots \ldots \ldots \ldots \ldots 44$

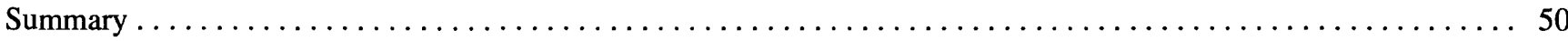

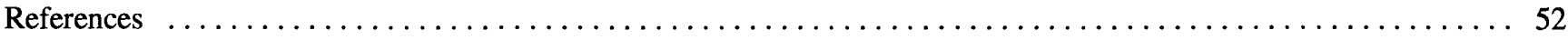

Appendix: Selected Water-Sampling Stations Included in the Water-Quality Assessment of the

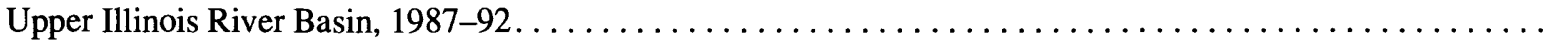

\section{FIGURES}

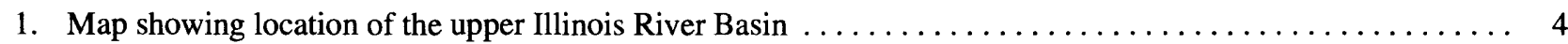

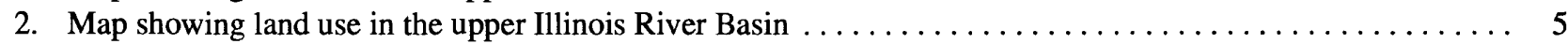

3. Graph showing flow-duration curves for water years 1948-91, 1978-86, and 1987-91 for

(A) Kankakee River near Wilmington, Ill., and (B) Des Plaines River at Riverside, Ill. . . . . . . . . . 6

4. Graph showing flow-duration curves for water years 1948-91, 1978-86, and 1987-91 for

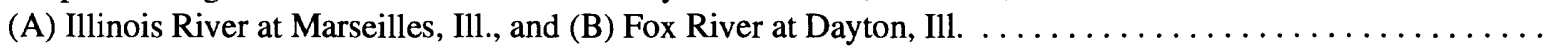

5-11. Maps showing:

5. Location of fixed-monitoring stations operated by the Illinois Environmental Protection Agency and the U.S. Geological Survey in the upper Illinois River Basin, water years 1987-91 . . . . . . . . . . . 9

6. Sampling sites for trace elements in fine-fraction streambed sediment in the upper Illinois River

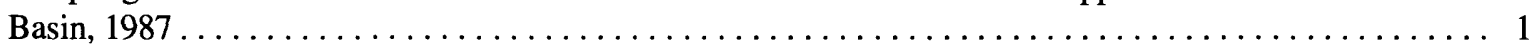

7. Sampling stations and sites used in the synoptic survey of organic compounds in streambed sediment

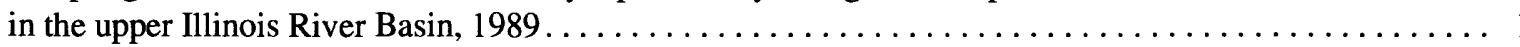

8. Sampling stations for manmade nonagricultural volatile and semivolatile organic compounds in stream

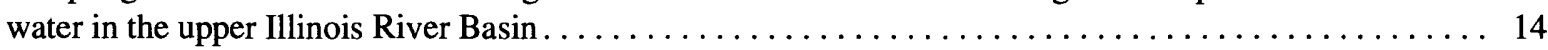

9. Sampling stations included in Phase I and Phase II pesticide in water sampling in the upper Illinois

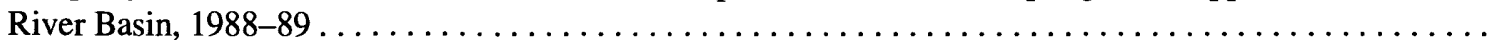

10. Sampling stations used in the synoptic sampling of nutrients, dissolved oxygen, and fecal-indicator bacteria in water in the upper Illinois River Basin . . . . . . . . . . . . . . . . . . . . . . . .

11. Sampling stations included in synoptic surveys for fish and macroinvertebrate tissue and communities

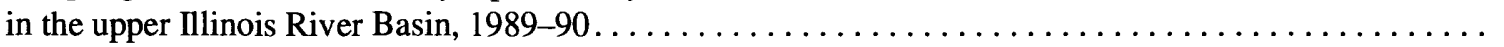

12. Normalized concentrations of selected trace inorganic constituents in the upper Illinois River Basin, 1989. 
13. Boxplots showing fine-grained streambed-sediment zinc concentrations, by stream order, in subbasins

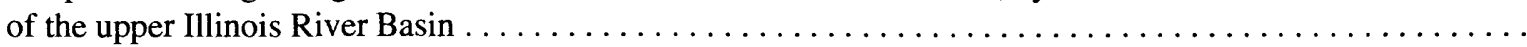

14. Graph showing exceedance probabilities for concentrations of chromium and lead in fine-fraction streambed-sediment samples from low- and high-order streams in the upper Illinois River Basin, 1989 . . . . .

15. Graph showing maximum concentrations, by land use, of herbicides that were detected in at least 50 percent of samples from either urban or agricultural stations in the upper Illinois River Basin, 1988-89 ...

16. Graph showing percent detections, by land use, of herbicides that were detected in at least 50 percent of samples from either urban or agricultural stations in the upper Illinois River Basin, 1988-89 ..........

17. Map showing location of stations where two or more volatile organic compounds were detected during a 1988 low-flow synoptic survey in the upper Illinois River Basin . . . . . . . . . . . . . . . . . .

18. Boxplots showing summary of available data for total phenolic compound concentrations at stations in

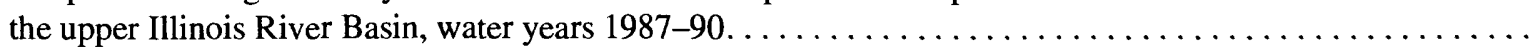

19. Graph showing concentrations of pentachlorophenol at the Illinois River at Marseilles, Ill. (05543500), water years 1981-92

Map showing spatial distribution of synthetic organic compounds in streambed sediment in the upper Illinois River Basin, 1989

1. Map showing loads of total nitrogen measured at the eight fixed-monitoring stations in the upper Illinois

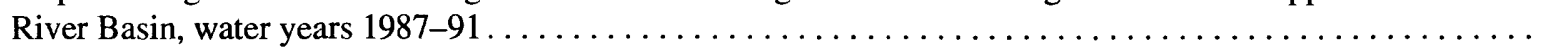

22. Map showing spatial distribution of dissolved oxygen concentrations in water measured during the low-flow synoptic survey in the upper Illinois River Basin, July $25-$ August $13,1988 \ldots \ldots \ldots \ldots \ldots \ldots$

23. Graph showing diel-variations in temperature and dissolved oxygen concentrations at three fixed-monitoring stations during the low-flow synoptic survey in the upper Illinois River Basin,

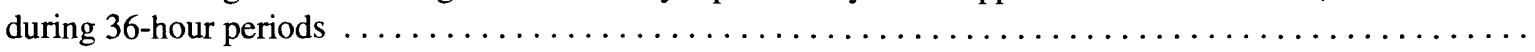

24. Boxplots showing chlorophyll-a concentrations in water measured at three fixed-monitoring stations in the upper Illinois River Basin, water years $1987-91 \ldots \ldots \ldots \ldots \ldots \ldots \ldots \ldots \ldots \ldots \ldots \ldots \ldots \ldots$

25. Map showing spatial distribution of Escherichia Coli bacteria densities in water measured during the low-flow synoptic survey in the upper Illinois River Basin, July 25-August 13, 1988 .

26. Graph showing exceedance probabilities for ammonia concentrations observed in the Calumet Sag Channel before and after implementation of the Tunnel and Reservoir Plan (TARP) system and improvements to aeration at the Calumet wastewater-treatment plant $\ldots \ldots \ldots \ldots \ldots \ldots \ldots \ldots \ldots$

27. Graph showing index of biotic integrity (IBI) scores for six sites in the Calumet Sag Channel before and after implementation of the Tunnel and Reservoir Plan (TARP) system and improvements to aeration at the Calumet wastewater-treatment plant $\ldots \ldots \ldots \ldots \ldots \ldots \ldots \ldots \ldots \ldots \ldots \ldots \ldots \ldots \ldots \ldots$

28. Boxplots showing detrended correspondence analyses (DCA) axis 1 site scales, Alternate Index of Biotic Integrity (AIBI) scores, concentrated total chromium in streambed sediments, concentration of total recoverable sodium, trace-element criteria ratios (TECR) for total arsenic, and concentration of total solids at sites in the Chicago/Little Calumet, Des Plaines, Du Page, and Fox River Basins .............

\section{TABLES}

1. Public water supply withdrawals in Cook County, Ill., for water years 1978, 1986, and $1990 \ldots \ldots \ldots \ldots$. . . .

2. Summary of sampling performed for the water-quality assessment of the upper Illinois River Basin,

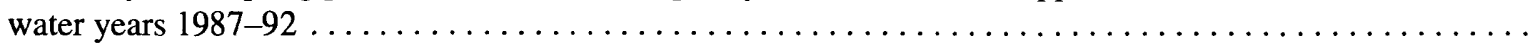

3. Summary of concentrations of organochlorine compounds in whole-fish samples from the upper Illinois

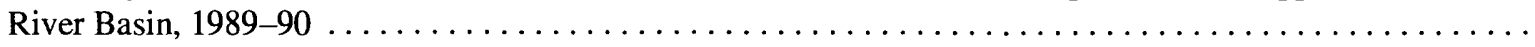

4. Correlation coefficients of compounds detected in over 50 percent of fish samples in the upper Illinois

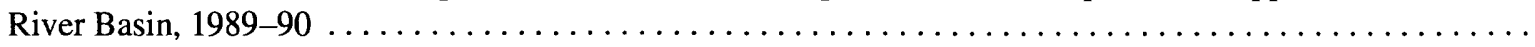

5. Statistical summary of nutrient concentrations at the eight fixed-monitoring stations in the upper

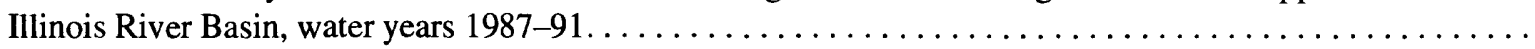

6. Correlation coefficients for nutrient concentrations and discharge at the eight fixed-monitoring stations

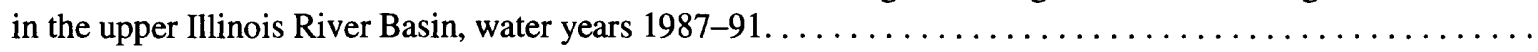

7. Statistical summary of dissolved oxygen concentrations at the eight fixed-monitoring stations in the

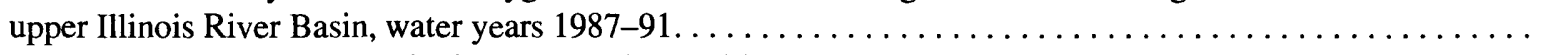

8. Statistical summary of fecal-indicator bacteria densities at the eight fixed-monitoring stations in the

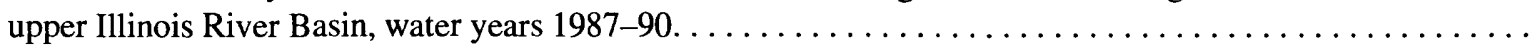


9. Relations of Federal water-quality criteria and State water-quality standards to bacteria densities at the eight fixed-monitoring stations in the upper Illinois River Basin, April 1987-August 1990 . . . . . . . . .

10. Statistical summary of concentrations of selected constituents and properties before and after implementation of the Tunnel and Reservoir Plan (TARP) system and improvements to aeration

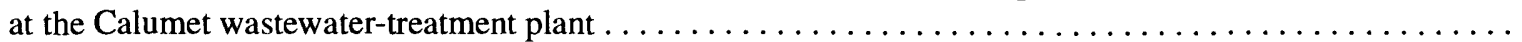

CONVERSION FACTORS AND VERTICAL DATUM

\begin{tabular}{|c|c|c|}
\hline Multiply & By & To obtain \\
\hline \multicolumn{3}{|c|}{ Length } \\
\hline mile (mi) & 1.609 & kilometer \\
\hline \multicolumn{3}{|c|}{ Area } \\
\hline square mile $\left(\mathrm{mi}^{2}\right)$ & 2.590 & square kilometer \\
\hline \multicolumn{3}{|c|}{ Flow rate } \\
\hline foot per second $(\mathrm{ft} / \mathrm{s})$ & 0.3048 & meter per second \\
\hline \multicolumn{3}{|c|}{ Mass } \\
\hline pound per acre (lb/acre) & 1.121 & kilogram per hectare \\
\hline ton per year (ton/yr) & 907.2 & kilograms per year \\
\hline
\end{tabular}

Temperature in degrees Fahrenheit $\left({ }^{\circ} \mathrm{F}\right)$ may be converted to degrees Celsius $\left({ }^{\circ} \mathrm{C}\right)$ as follows:

$$
{ }^{\circ} \mathrm{C}=\left({ }^{\circ} \mathrm{F}-32\right) / 1.8
$$

Sea level: In this report, "sea level" refers to the National Geodetic Vertical Datum of 1929 (NGVD of 1929)-a geodetic datum derived from a general adjustment of the first-order level nets of both the United States and Canada, formerly called Sea Level Datum of 1929.

Altitude, as used in this report, refers to distance above or below sea level.

Concentrations of chemical constituents in water are given either in milligrams per liter $(\mathrm{mg} / \mathrm{L})$ or micrograms per liter $(\mu \mathrm{g} / \mathrm{L})$. Concentrations of chemical constituents in sediment are given in micrograms per gram $(\mu \mathrm{g} / \mathrm{g})$. Concentrations of fecal-coliform bacteria are given in colonies per 100 milliliters (col/100 mL). 


\section{SURFACE-WATER-QUALITY ASSESSMENT OF THE UPPER ILLINOIS RIVER BASIN IN ILLINOIS, INDIANA, AND WISCONSIN-RESULTS OF INVESTIGATIONS THROUGH APRIL 1992}

By Arthur R. Schmidt and Stephen F. Blanchard Abstract

A water-quality assessment of the upper Illinois River Basin (10,949 square miles) was conducted during water years 1987-91. This assessment involved interpretation of available data; 4 years of intensive data collection, including monthly sample collection at eight fixed-monitoring stations in the basin; and synoptic studies of selected water-quality constituents at many sites.

The number of exceedances of waterquality criteria for chromium, copper, lead, mercury, silver, and zinc in water was essentially the same at similar stations between 1978-86 and 1987-90. For water and sediment, a large signature for many trace inorganic constituents was observed from the Chicago metropolitan area, mainly from the Des Plaines River Basin and continuing down the Illinois River. Loads of trace inorganic constituents in water were 2-13 times greater from the Chicago metropolitan area than from rural areas in the upper Illinois River Basin.

Concentrations of cadmium, mercury, nickel, selenium, and zinc appeared to be relatively enriched in biota in the upper Illinois River Basin compared to other river basins. Biota from some urban sites were enriched with respect to several elements. For example, relatively large concentrations of cadmium, chromium, copper, lead, and nickel were observed in biota from sites in the Chicago River in the metropolitan area and the Calumet River.
Results of pesticide sampling in 1988 and 1989 identified the pesticides bromacil, diazinon, malathion, prometon, and simazine as urban related and alachlor, atrazine, cyanazine, metolachlor, and metribuzin as agricultural related.

Phenol concentrations never exceeded general-use and secondary-contact water-quality standards of 100 and 300 micrograms per liter, respectively. Pentachlorophenol concentrations observed at the Illinois River at Marseilles, Ill., between 1981 and 1992 decreased beginning in 1987

A breakdown product of the organochlorine pesticide dichloro-diphenyl-trichloroethane (DDT), $p, p^{\prime}$-DDE was the most commonly detected organic compound in biota in both 1989 and 1990. In the nine fish-fillet samples collected in 1989, exceedances of U.S. Environmental Protection Agency (USEPA) fish tissue concentrations were noted for $p, p^{\prime}$-DDE in all nine fillets and for dieldrin in five of the nine fillets.

Nutrient concentrations in water in the study area generally were larger than concentrations typically found in natural waters. The Des Plaines River Basin contributed approximately 41 percent of the total nitrogen load to the upper Illinois River Basin, whereas the Kankakee River and Iroquois River Basins contributed about 34 and 14 percent of the total load, respectively.

Dissolved oxygen concentrations measured during a 1988 synoptic sampling exceeded State water-quality standards at 76 percent of the 
sampled sites. Bacteria densities greater than water-quality standards were observed at all of the fixed-monitoring stations, but densities greater than water-quality criteria and standards were observed more often at stations in the Des Plaines River Basin.

Results from the analysis of changes in water quality following changes in wastewatertreatment practices indicated that current monitoring programs, although sufficient for their intended purposes, are not suitable for this type of retrospective assessment in large-scale water-quality assessments. Changes were not indicated in fish-community structure and population following changes in wastewatertreatment practices.

A strong relation between the quality of the fish community and overall water-quality conditions was observed, although USEPA acute criteria for the protection of freshwater aquatic life were rarely exceeded. Analyses of fish-community data clearly showed that water quality in the urbanized parts of the study area were degraded relative to those in agricultural areas. Total chromium in streambed sediments and total recoverable sodium in water were highly correlated with the fish community.

\section{INTRODUCTION}

\section{Background}

In 1985, the Congress appropriated funds for the U.S. Geological Survey (USGS) to test and refine concepts for a National Water-Quality Assessment (NAWQA) Program. The NAWQA Program is designed to address a wide range of water-quality issues, which include chemical contamination, acidification, eutrophication, salinity, sedimentation, sanitary quality, and degradation of the aquatic ecosystems. The long-term goals of the program are to (1) provide a nationally consistent description of current water-quality conditions for a large part of the Nation's water resources; (2) define long-term trends (or lack of trends) in water quality; and (3) identify, describe, and explain, as possible, the major factors that affect current conditions and trends in water quality. This information will provide an improved scientific basis for evaluating the effectiveness of water-quality management programs and determining the likely effects of contemplated changes in land- and water-management practices to water managers, policy makers, and the public.

The NAWQA Program began as a pilot program in 1986 to test and refine assessment concepts for a fully implemented national program. The upper Illinois River Basin was one of four river basins used to refine the concepts for assessing surface water. A waterquality assessment of the upper Illinois River Basin started in 1986. The first 2 years involved interpretation of available data and planning of future activities, followed by 4 years of intensive data collection. Datacollection activities included monthly sampling at a small number of stations to document temporal variability of constituent concentration. Synoptic studies were conducted at many sites to document the spatial variability of constituent concentrations under specific hydrologic conditions. Concentrations of selected constituents were determined for various media, including water, suspended sediment, streambed sediment, and fish tissues to provide multiple types of assessment. Additional special studies were done to (1) determine the availability and suitability of information on municipal wastewater-treatment practices for largescale water-quality assessments; (2) identify changes in stream-water quality that could be related to changes in wastewater collection and treatment; and (3) develop protocols for sampling and analysis of fish and macroinvertebrate communities, and relating these communities to water quality.

In this report, station refers to those locations where a USGS identification number was assigned and, generally, more than one sample was collected for analysis of water quality during the study period. Site refers to those locations where no USGS identification number was assigned and, generally, only one sample was collected for analysis of water quality, usually as part of a synoptic survey.

\section{Purpose and Scope}

This report summarizes the results of data collected and analyzed as part of the upper Illinois River Basin NAWQA pilot study in Illinois, Indiana, and Wisconsin from 1986 to 1995 . As a summary of the study, this report is limited to selected important results. Details about data collection and interpretation 
are presented in other reports completed as part of this study (Blanchard and Schmidt, in press; Colman and Sanzolone, 1991; Colman and Sanzolone, 1992; Fitzpatrick and others, 1995; Fitzpatrick and Colman, 1993; Marron and Blanchard, 1995; Mades, 1987; Ruhl, 1995; Steffeck and Striegl, 1989; Sullivan and Blanchard, 1994; Sullivan and others, in press; Sullivan and Terrio, 1994; Terrio, 1994a; Terrio, 1994b; Zogorski and others, 1990).

\section{DESCRIPTION OF THE UPPER ILLINOIS RIVER BASIN}

The upper Illinois River Basin drains $10,949 \mathrm{mi}^{2}$ of Illinois, Indiana, and Wisconsin and has a mean annual discharge of $12,500 \mathrm{ft}^{3} / \mathrm{s}$. The upper Illinois River Basin is composed of four principal river systems (fig. 1): The Kankakee, which drains $5,165 \mathrm{mi}^{2}$ and contributes 36 percent of the mean annual discharge from the basin; the Fox, which drains $2,658 \mathrm{mi}^{2}$ and contributes 14 percent of the mean annual discharge from the basin; the Des Plaines (except the Chicago Sanitary and Ship Canal), which drains $1,371 \mathrm{mi}^{2}$ and contributes 8 percent of the mean annual discharge from the basin; and the Chicago Sanitary and Ship Canal, which drains $740 \mathrm{mi}^{2}$ and contributes 42 percent of the mean annual discharge from the basin. The high percentage of discharge contributed by the Chicago Sanitary and Ship Canal is the result of water that is diverted from Lake Michigan and returned to the canal. Land use in the basin is 75 percent agricultural, 20 percent urban, and 5 percent forest (fig. 2).

The population in 1990 in the upper Illinois River Basin was 7.6 million. Census data from all counties in the study area (not corrected for the portion of each county outside the study area) indicate that the population in the study area increased by about 1.5 percent from 1980 to 1990 . The data also indicated a shift in population from the metropolitan areas to outlying areas. For example, the population of Cook County, Ill., which contains the city of Chicago, decreased by 150,000 from 1980 to 1990 , while the population in the four adjacent counties (Du Page, Kane, Lake, and McHenry) increased by a total of 270,000 .

\section{Surface-Water Hydrology and Climate, 1987-90}

Runoff in the study area ranges from $8 \mathrm{in} / \mathrm{yr}$ in the Wisconsin part of the study area and increases to the south and east to $12 \mathrm{in} / \mathrm{yr}$ in parts of Illinois and Indiana. Mean-annual precipitation in the study area ranges from $32 \mathrm{in} / \mathrm{yr}$ in Wisconsin and increases to the south and east to $40 \mathrm{in} / \mathrm{yr}$ in parts of Indiana (Moody and others, 1986, p. 215-236, 485-492).

Mean discharges observed during the period of this study (water years ${ }^{1}$ 1987-91) were greater than those observed over the period of record but were not as large as during the period used for the analysis of available data (water years 1978-86). Data from water years 1948-91 corresponded with the period of record for the precipitation stations and were used in the analysis of available data. The flow-duration curves for water years 1948-91, 1978-86, and 1987-91 for flow from four stations measuring the major subbasins of the upper Illinois River Basin (Kankakee River near Wilmington, Ill., 05527500; Des Plaines River at Riverside, Ill., 05532500; Illinois River at Marseilles, Ill., 05534500; and Fox River at Dayton, Ill., 05552500) are shown for comparison in figures 3 and 4. The curves for water years 1987-91 generally fall between the curves for water years 1948-91 and 1978-86 indicating that discharges during water years 1987-91 were smaller than during 1978-86 but larger than during 1948-91. The greatest differences between the curves were for lower discharges, those that were exceeded more than 50 percent of the time. The curves show that the low flows during water years 1978-86 and 1987-91 were greater than the low flows from the period of record. This especially applies to the stations with a large percentage of urban land use in their drainage basin as shown by the curves for the Des Plaines River at Riverside (05532500).

Precipitation observed during the period of this study (water years 1987-91) was not significantly different from that observed during the period of record (1948-91) and the period used for the analysis of available data (1978-86). The discharge and precipitation analyses indicate that precipitation in the upper Illinois River Basin has not changed appreciably over the

\footnotetext{
${ }^{1}$ The water year is the 12 -month period from October 1 through September 30 and is designated by the calendar year in which it ends and which includes 9 of the 12 months.
} 


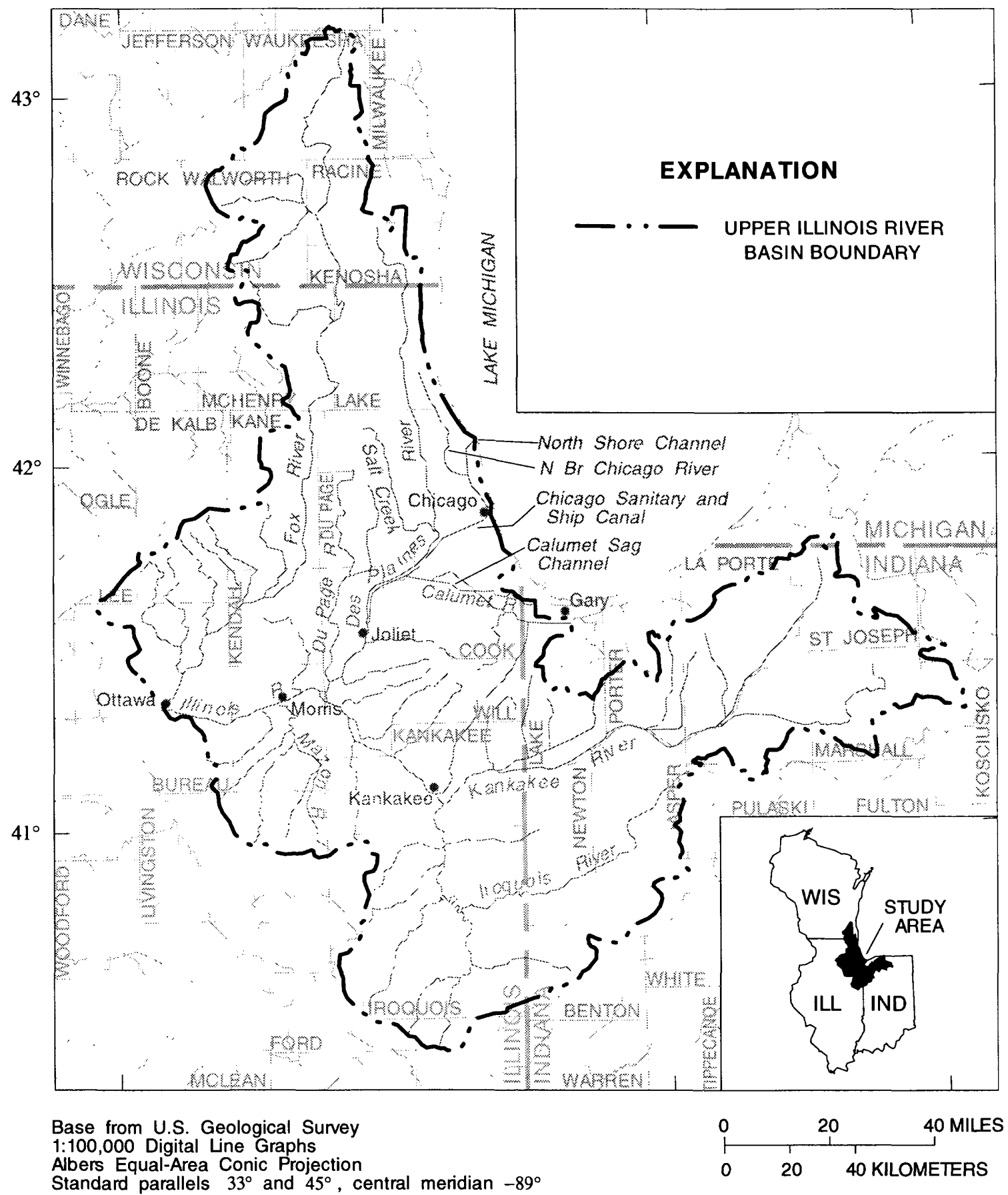

Figure 1. Location of the upper Illinois River Basin. 


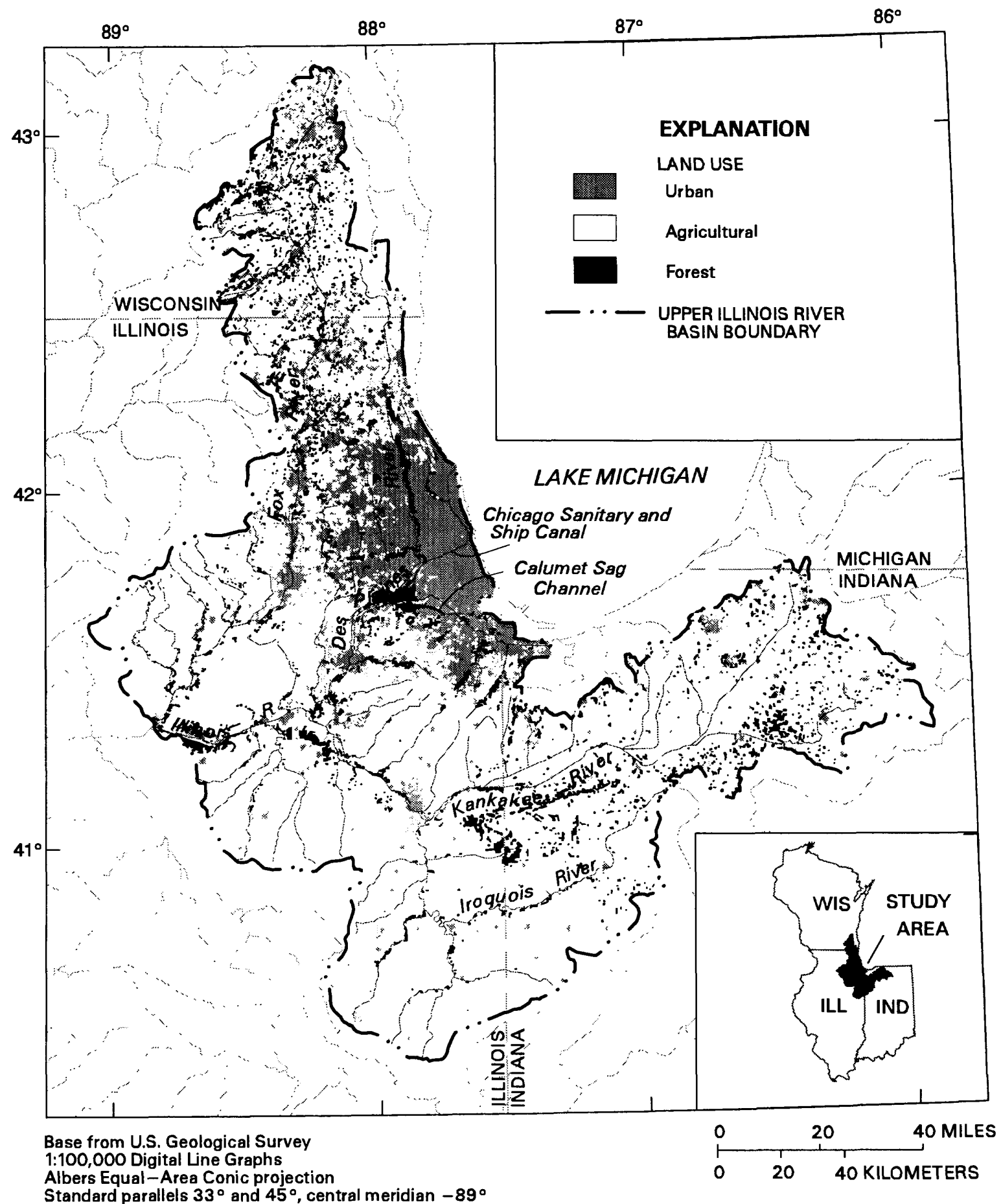

Figure 2. Land use in the upper Illinois River Basin. 


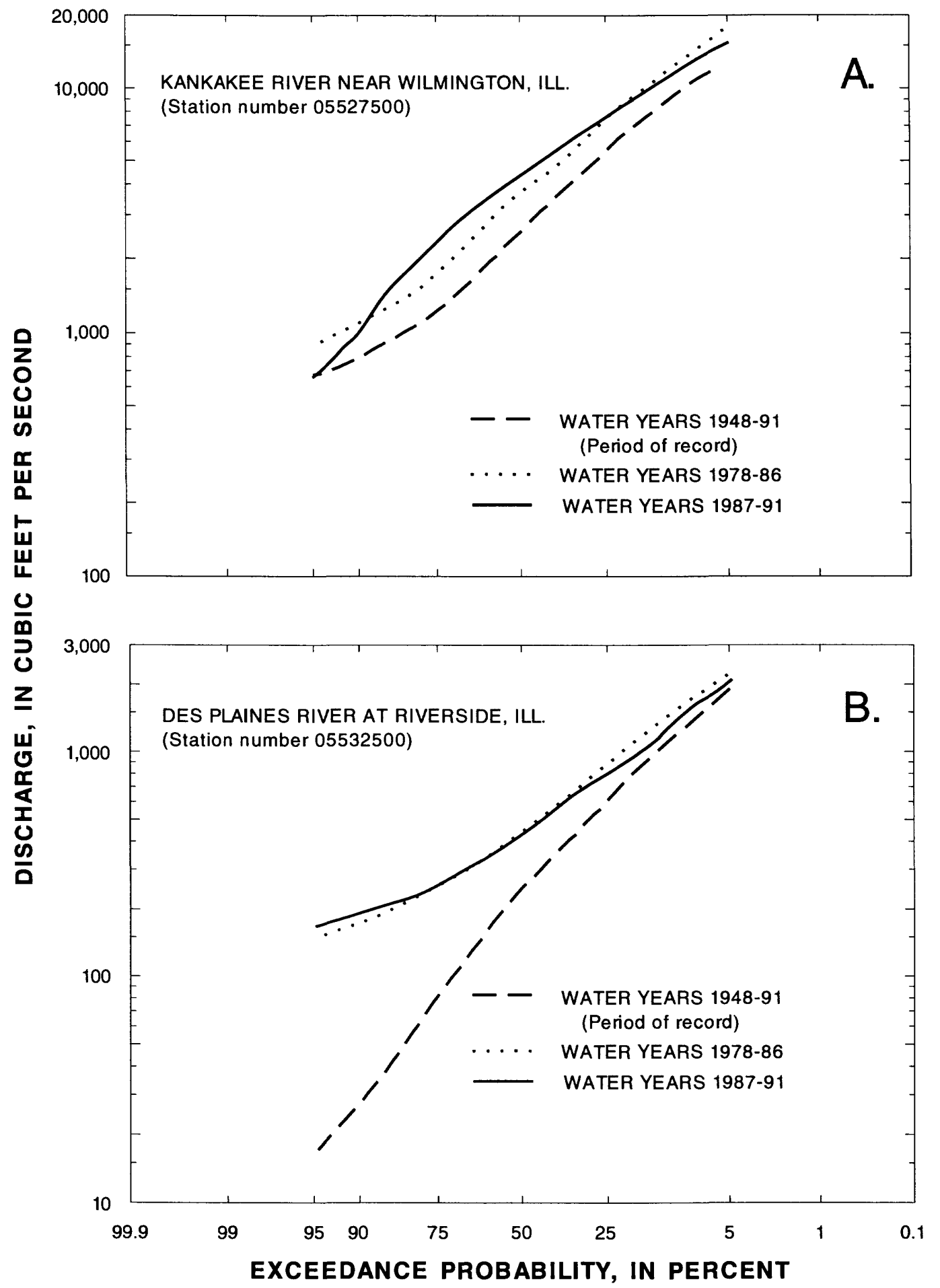

Figure 3. Flow-duration curves for water years 1948-91, 1978-86, and 1987-91 for (A) Kankakee River near Wilmington, III. and (B) Des Plaines River at Riverside, III. 


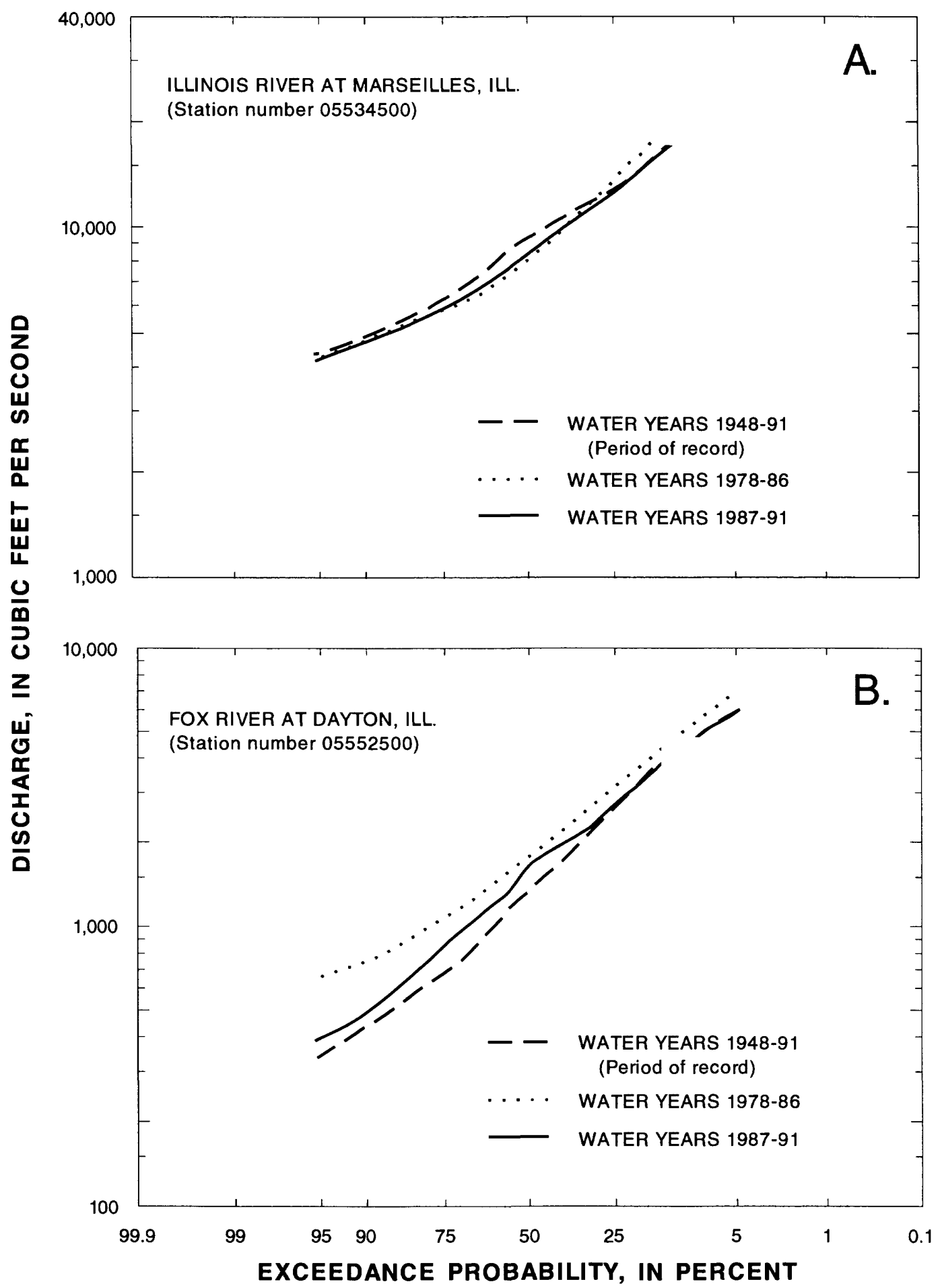

Figure 4. Flow-duration curves for water years 1948-91, 1978-86, and 1987-91 for (A) Illinois River at Marseilles, III., and (B) Fox River at Dayton, III. 
period of record, but the discharge in the basin has increased appreciably over the same period.

\section{Water Use, 1987-90}

Average daily water use in the study area in 1985 was about $9,000 \mathrm{Mgal} / \mathrm{d}$. About 19 percent of the water used is withdrawn from Lake Michigan, 76 percent is from surface waters other than Lake Michigan, and 5 percent is ground water from aquifers. Withdrawals from Lake Michigan and aquifers represent water imported to the surface-water system in the study area that contributes to the large amount of return flow.

Several communities in the Chicago metropolitan area changed from ground water to Lake Michigan as their primary water supply in the late 1970's and 1980 's. The withdrawals for public water supply for Cook County, Ill., for 1978, 1986, and 1990 water years are listed in table 1 . Approximately 80 percent of the total water withdrawals for the public water supply for the study area are from Cook County. Total water withdrawals for the whole study area for public water supply remained essentially unchanged between 1978 and 1990 - ground-water withdrawals were reduced by 75 percent, whereas surface-water withdrawals increased.

\section{SUMMARY OF SAMPLING PROGRAMS, APRIL 1987-APRIL 1992}

Water and suspended-sediment samples were collected at 40 fixed-monitoring stations between 1987 and 1991. The Illinois Environmental Protection Agency (IEPA) collected water samples from 38 of the 40 stations in the upper Illinois River Basin from 1978 to 1991. Eight of the 40 stations were sampled monthly, whereas the rest were sampled every 6 weeks. Water samples from all 40 of these sampling stations were analyzed by the IEPA laboratory. Suspended-sediment samples and periodic quality-assurance water samples were analyzed by the USGS National Water Quality Laboratory (NWQL) in Arvada, Colo. The location of the eight more intensely monitored stations, operated as part of the NAWQA study of the upper Illinois River Basin, and the additional 32 stations, operated by the IEPA, are shown in figure 5. Additional information for these 32 stations is given in Blanchard and Schmidt (in press).

Water, streambed sediment, suspended sediment, and fish-tissue samples were collected during several synoptic studies performed between 1988 and 1990 (table 2). Streambed-sediment samples were collected at 238 randomly selected sites on low-order streams and 134 sites spaced at regular intervals on high-order streams during fall 1987 (fig. 6) (Colman and Sanzolone, 1991). Fish-tissue samples were collected at 12 stations during the summer of 1989 and at 22 stations during the summer of 1990 . Streambedsediment samples were collected in 1989 and 1990 in conjunction with the fish-tissue sampling. The NAWQA synoptic sampling of trace inorganic constituents in streambed sediment significantly extended the coverage of available data for these constituents. The available data for 77 sites and stations on the main stem streams in Illinois were extended to 436 main stem and first- and second-order stream sites in Illinois, Indiana, and Wisconsin, and increased the coverage from 10 to 46 elements. The NAWQA sampling program for organic compounds was designed to augment available data; sampling was expanded to include locations and compounds not previously sampled. Sampling periods, sampling media, target constituents, and sampling frequencies used in this assessment are listed in table 2.

Table 1. Public water supply withdrawals in Cook County, III., for water years 1978, 1986, and 1990

[Data from aggregated water use data system (AWUDS), Stephen R. Tarte, U.S. Geological Survey, written commun., January 12, 1994; $\mathrm{Mgal} / \mathrm{d}$, million gallons per day]

\begin{tabular}{cccc}
\hline Water year & $\begin{array}{c}\text { Ground-water } \\
\text { withdrawals } \\
\text { (Mgal/d) }\end{array}$ & $\begin{array}{c}\text { Surface-water } \\
\text { withdrawals } \\
\text { (Mgal/d) }\end{array}$ & $\begin{array}{c}\text { Total public } \\
\text { water supply } \\
\text { withdrawals } \\
\text { (Mgal/d) }\end{array}$ \\
\hline 1978 & 79.7 & 1,046 & 1,125 \\
1986 & 40.9 & 1,083 & 1,124 \\
1990 & 20.0 & 1,103 & 1,123 \\
\hline
\end{tabular}




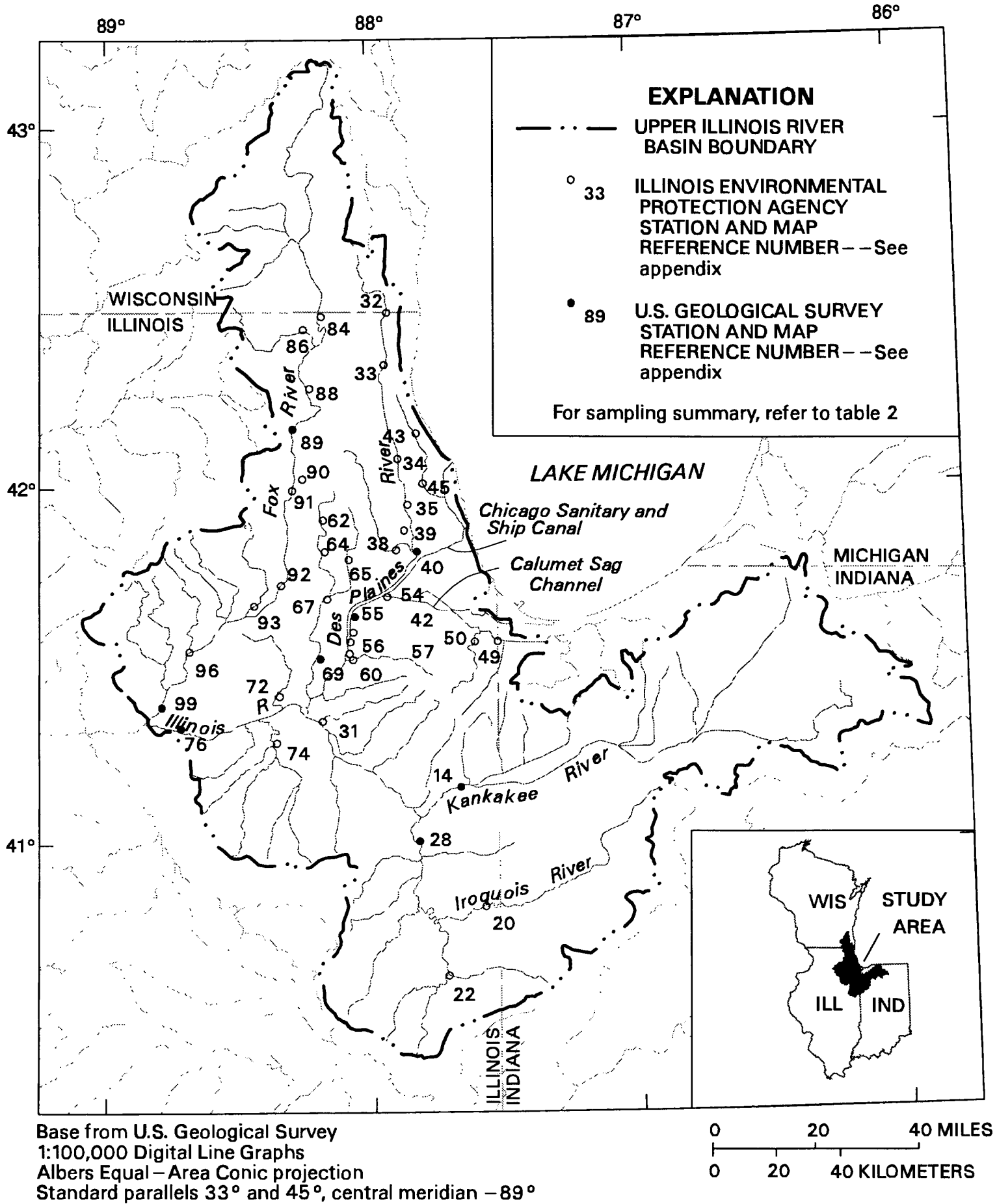

Figure 5. Location of fixed-monitoring stations operated by the Illinois Environmental Protection Agency and the U.S. Geological Survey in the upper Illinois River Basin, water years 1987-91. 
Table 2. Summary of sampling performed for the water-quality assessment of the upper Illinois River Basin, water years $1987-92$

[Bed, streambed sediment; VOC's, volatile organic compounds; BNA, base- neutral-, and acid-extractable organic compounds;

DO, dissolved oxygen; fecal, fecal-indicator bacteria]

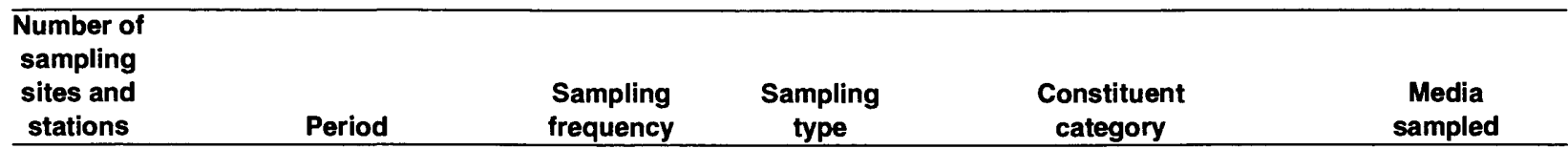

\begin{tabular}{|c|c|c|c|c|c|}
\hline \multicolumn{6}{|c|}{ Major- and Trace-Inorganic Constituents } \\
\hline 8 & Apr. 1987-Aug. 1990 & Monthly & Fixed station & Inorganic & Water \\
\hline 8 & Apr. 1987-Aug. 1990 & Monthly & Fixed station & Inorganic & Suspended sediment \\
\hline 4 & Sept. 1990-Apr. 1992 & Monthly & Fixed station & Inorganic & Water \\
\hline 4 & Sept. 1990-Sept. 1991 & Bimonthly & Fixed station & Inorganic & Suspended sediment \\
\hline 373 & Fall 1987 & Once & Synoptic & Inorganic & Bed \\
\hline 16 & Summer 1989 & Once & Synoptic & Inorganic & Water \\
\hline 16 & Summer 1989 & Once & Synoptic & Inorganic & Biota \\
\hline 25 & Summer 1990 & Once & Synoptic & Inorganic & Bed \\
\hline 25 & Summer 1990 & Once & Synoptic & Inorganic & Biota \\
\hline \multicolumn{6}{|c|}{ Organic Compounds } \\
\hline 2 & Aug. 1988-Mar. 1990 & Monthly & Fixed station & Organic & Water \\
\hline 31 & July 1988 & Once & Synoptic & VOC's & Water \\
\hline 21 & July 1988 & Once & Synoptic & BNA & Water \\
\hline 16 & Summer 1989 & Once & Synoptic & Organic & Biota \\
\hline 83 & Aug. 1989 & Once & Synoptic & Organic & Bed \\
\hline 25 & Summer 1990 & Once & Synoptic & Organic & Bed \\
\hline 25 & Summer 1990 & Once & Synoptic & Organic & Biota \\
\hline 4 & $\begin{array}{l}\text { Summer } 1988 \text { and } \\
\text { summer } 1989\end{array}$ & Variable $^{1}$ & Runoff event & $\begin{array}{l}\text { Herbicides and } \\
\text { insecticides }\end{array}$ & Water \\
\hline 17 & Summer 1990 & Variable $^{2}$ & Runoff event & Herbicides & Water \\
\hline \multicolumn{6}{|c|}{ Dissolved Oxygen, Nutrients, Fecal-Indicator Bacteria, and General ${ }^{3}$} \\
\hline 8 & Apr. 1987-Aug. 1990 & Monthly & Fixed station & General & Water \\
\hline 4 & Sept. 1990-Apr. 1992 & Monthly & Fixed station & General & Water \\
\hline${ }^{4} 32$ & $\begin{array}{l}\text { Prior to } 1986 \text { to } \\
\text { present }\end{array}$ & 6 weeks & Fixed station & General & Water \\
\hline 20 & Aug. 1987 & Once & Synoptic & Nutrients and DO & Water \\
\hline 59 & July 1988-Aug. 1988 & Once $e^{5}$ & Synoptic & Nutrients, DO, and fecal & Water \\
\hline \multicolumn{6}{|c|}{ Biological Survey } \\
\hline 12 & Summer 1989 & Twice $^{6}$ & Synoptic & Community & Biota \\
\hline 22 & Summer 1990 & Twice $^{7}$ & Synoptic & Community & Biota \\
\hline
\end{tabular}

\footnotetext{
${ }^{1}$ Total of 25 samples collected during 4 storms and intervening low-flow periods.

${ }^{2}$ More than 400 samples collected during 3 major storms and intervening low-flow periods.

${ }^{3}$ Includes measurement of physical parameters, nutrients, fecal coliform and Escherichia coli bacteria, major ions, chemical oxygen demand, suspended solids, and 21 metals.

${ }^{4}$ Sampled by the Illinois Environmental Protection Agency.

${ }^{5}$ Four stations were sampled hourly for a 24-hour period.

${ }^{6}$ Fish-community samples collected at all stations; invertebrate-community and algae samples and habitat data also collected at selected stations.

${ }^{7}$ Fish-community samples collected at all stations; invertebrate-community and algae samples and habitat data also collected at selected
} 


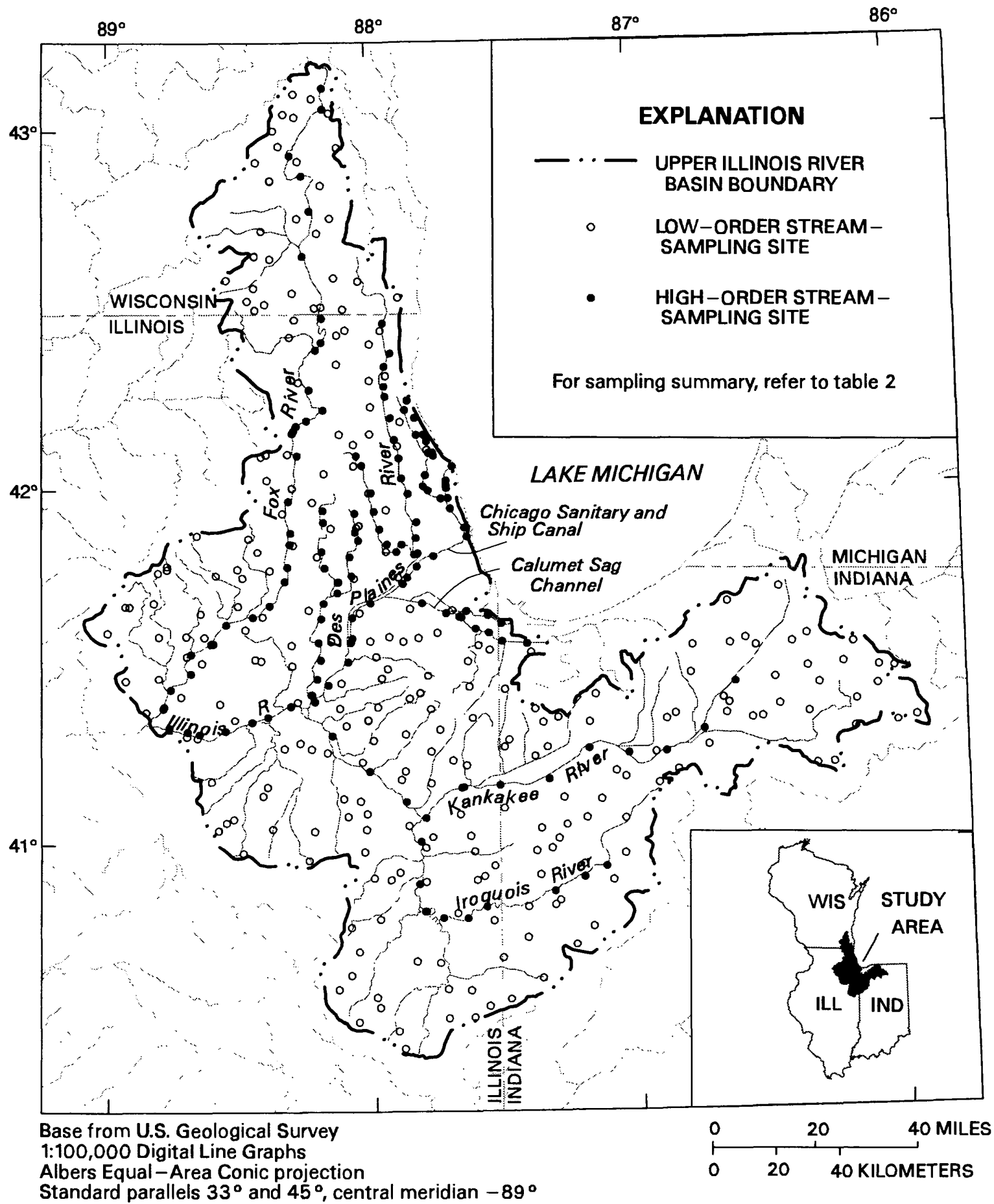

Figure 6. Sampling sites for trace elements in fine-fraction streambed sediment in the upper Illinois River Basin, 1987. 
Sampling stations included in the water-quality assessment of the upper Illinois River Basin are listed in the appendix. Synoptic sampling sites for organic compounds and trace elements in streambed sediment are not listed. The locations of the sampling sites and stations used in this assessment are shown in figures 6-11.

\section{WATER-QUALITY CONDITIONS (1987-91) AND TRENDS (1978-91) IN THE UPPER ILLINOIS RIVER BASIN}

The water-quality assessment of the upper Illinois River Basin targeted different groups of constituents for sampling and analysis. The observed water-quality conditions and trends in the study area for these constituent groups are described in this section. The spatial distribution of concentrations from three different media (water, sediment, and biota) is summarized and compared with water-quality standards and factors that may affect concentrations in the media. These factors include land use, location of point sources, and flow conditions.

\section{Trace Inorganic Constituents}

Trace inorganic constituents include alkalineearth metals, transition metals, other metallic elements at the end of the transition series, and nonmetallic elements; many of these elements are naturally in low concentrations in surface water. Trace elements are defined as elements that normally are present in water at concentrations of less than $1 \mathrm{mg} / \mathrm{L}$ (Hem, 1985). Concentrations greater than $1 \mathrm{mg} / \mathrm{L}$ may result from weathering of ore-bearing rocks and sediments, industrial and municipal effluents, urban and agricultural runoff, and atmospheric deposition. Twelve of the trace inorganic constituents have been listed by the U.S. Environmental Protection Agency (USEPA) as priority pollutants. These are antimony, arsenic, beryllium, cadmium, chromium, copper, lead, mercury, selenium, silver, and zinc.

Results of sampling three media indicate that many major and trace inorganic constituents are elevated or enriched (above background concentrations) in the upper Illinois River Basin. A description of the method for determining background concentrations is presented in Fitzpatrick and others (1995). However, those elements that were elevated at sites in one media were not necessarily elevated in all three media at the same sites.

Concentrations in water and fine-grained (<62 micrometers) streambed sediment from 1978 to 1986 are similar to concentrations in water and finegrained streambed sediment from 1987 to 1990 . The number of exceedances of water-quality criteria for chromium, copper, lead, mercury, silver, and zinc in water were essentially the same at similar stations (mainly in the Des Plaines River Basin) between these periods (Fitzpatrick and others, 1995, p. 29). The results from this study are not adequate to evaluate whether exceedances in water affected the healthy propagation and distribution of biological communities.

Some of the most intensively used urban and industrial land within the basin is in the Chicago metropolitan area, although concentrations of many of the trace inorganic constituents in water were below the minimum reporting level, which limited the degree of analysis. Analytical techniques with lower minimum reporting levels are required to evaluate the occurrence and distribution of trace inorganic constituents in water in the basin, especially in nonurban areas. Minimum reporting levels used in this study were just low enough to adequately classify concentrations that exceeded water-quality criteria.

In general, the spatial distribution of trace inorganic constituents in the upper Illinois River Basin indicated enrichment from the urban areas. For water and fine-grained sediment, a large signature for many of the trace inorganic constituents was observed from the Chicago metropolitan area, mainly from the Des Plaines River Basin and continuing down the Illinois River. Loads of trace inorganic constituents in water were 2-13 times greater from the Chicago metropolitan area than from rural areas in the upper Illinois River Basin. The signature of elevated concentrations from the Chicago metropolitan area in water and sediment was observed in the Illinois River downstream from the confluence of the Des Plaines and Kankakee Rivers. The pattern of enrichment of normalized concentrations of trace inorganic constituents from the Chicago area is shown in figure 12. In the normalization, concentration values were converted to a zero-to-one scale by subtracting the lowest basinwide concentration from each value and dividing the difference by the range in concentrations for the basin (highest concentration minus lowest concentration) (Colman and Sanzolone, 1991, p. 938). 


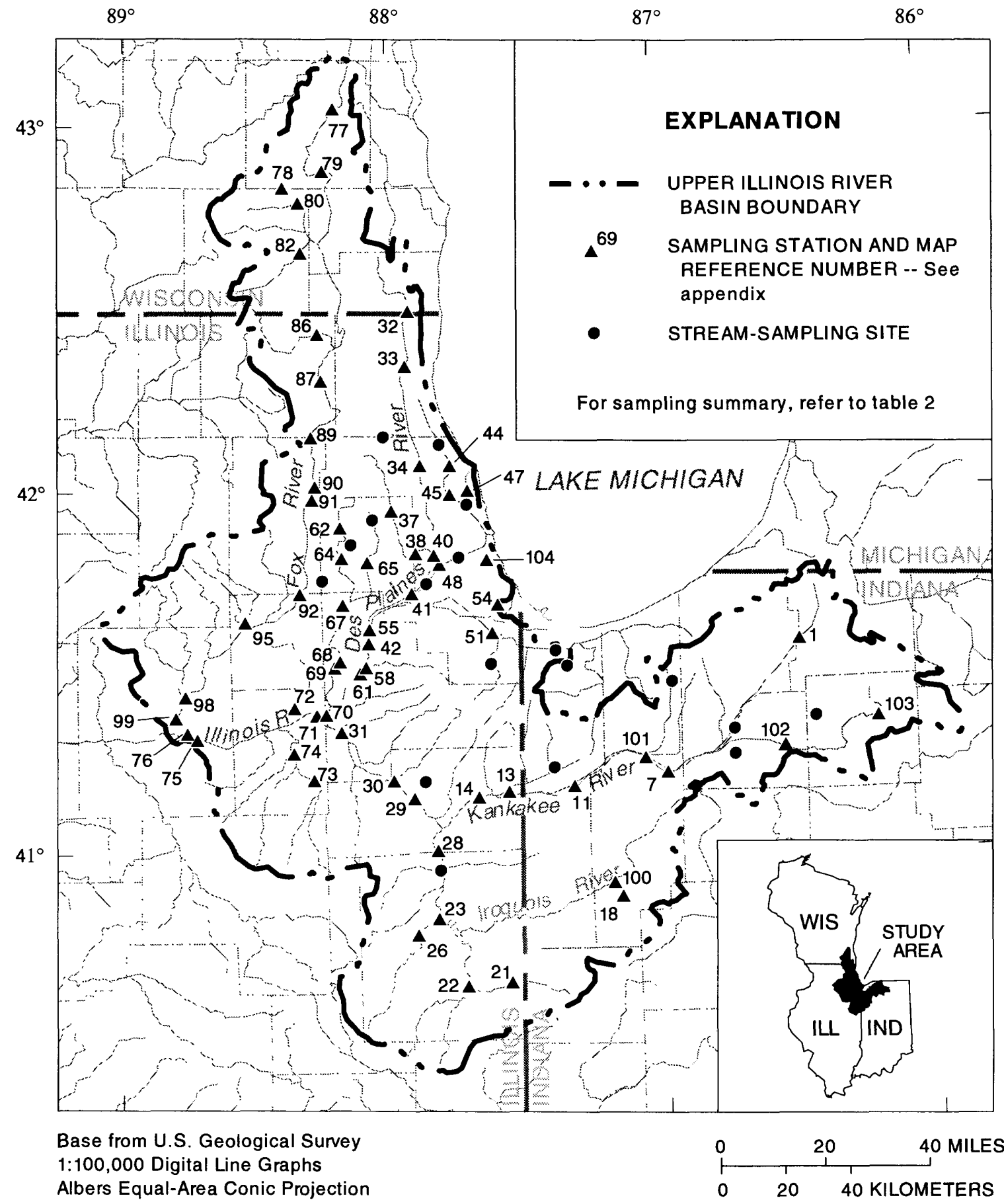

Standard parallels $33^{\circ}$ and $45^{\circ}$, central meridian $-89^{\circ}$

Figure 7. Sampling stations and sites used in the synoptic survey of organic compounds in streambed sediment in the upper Illinois River Basin, 1989.

The highest arsenic concentrations in water, sediment (Colman and Sanzolone, 1992), and biota were observed at sites in the upper Kankakee River Basin. Agricultural use of arsenic-based chemicals (insecticides, herbicides, algaecides, and desiccants) has resulted in the largest anthropogenic source of arsenic in the environment (Woolson, 1975, as cited in Eisler, 1988a). However, agricultural use of arsenic alone cannot explain the higher concentrations in the upper Kankakee River Basin because the Iroquois 


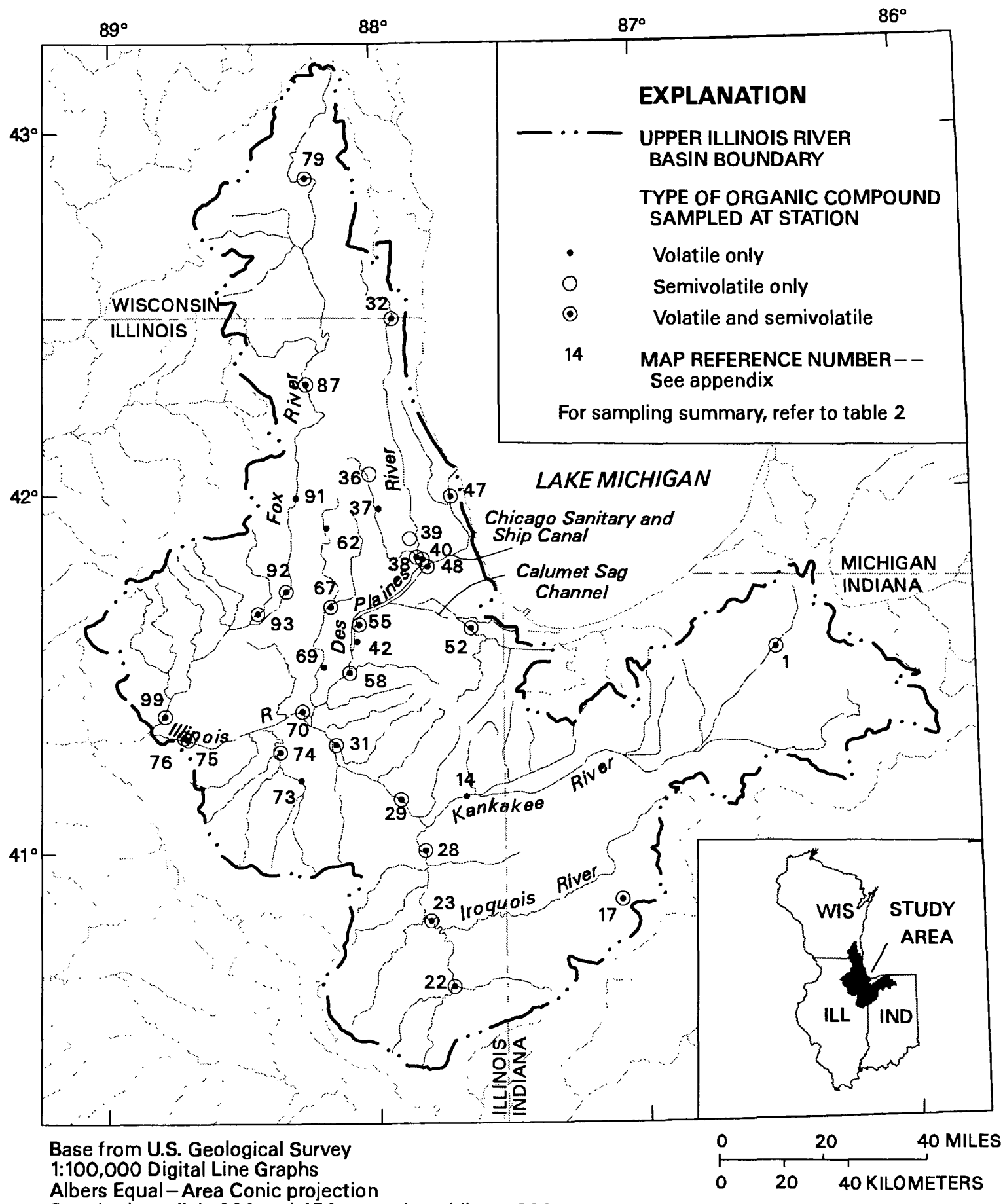

Standard parallels $33^{\circ}$ and $45^{\circ}$, central meridian $-89^{\circ}$

Figure 8. Sampling stations for manmade nonagricultural volatile and semivolatile organic compounds in stream water in the upper Illinois River Basin.

River, which is a tributary to the Kankakee River, drains an area with a higher percentage of agricultural land (96 percent) but with lower concentrations of arsenic in all three media. Arsenic concentrations in the upper Kankakee River appear to be affected by more than just the source. The high arsenic signature in the upper Kankakee River Basin is affected by properties of the geochemical substrate, such as differences in the particle size of sediments in the two basins. It is possible that the lack of fine-grained sediments in the upper 


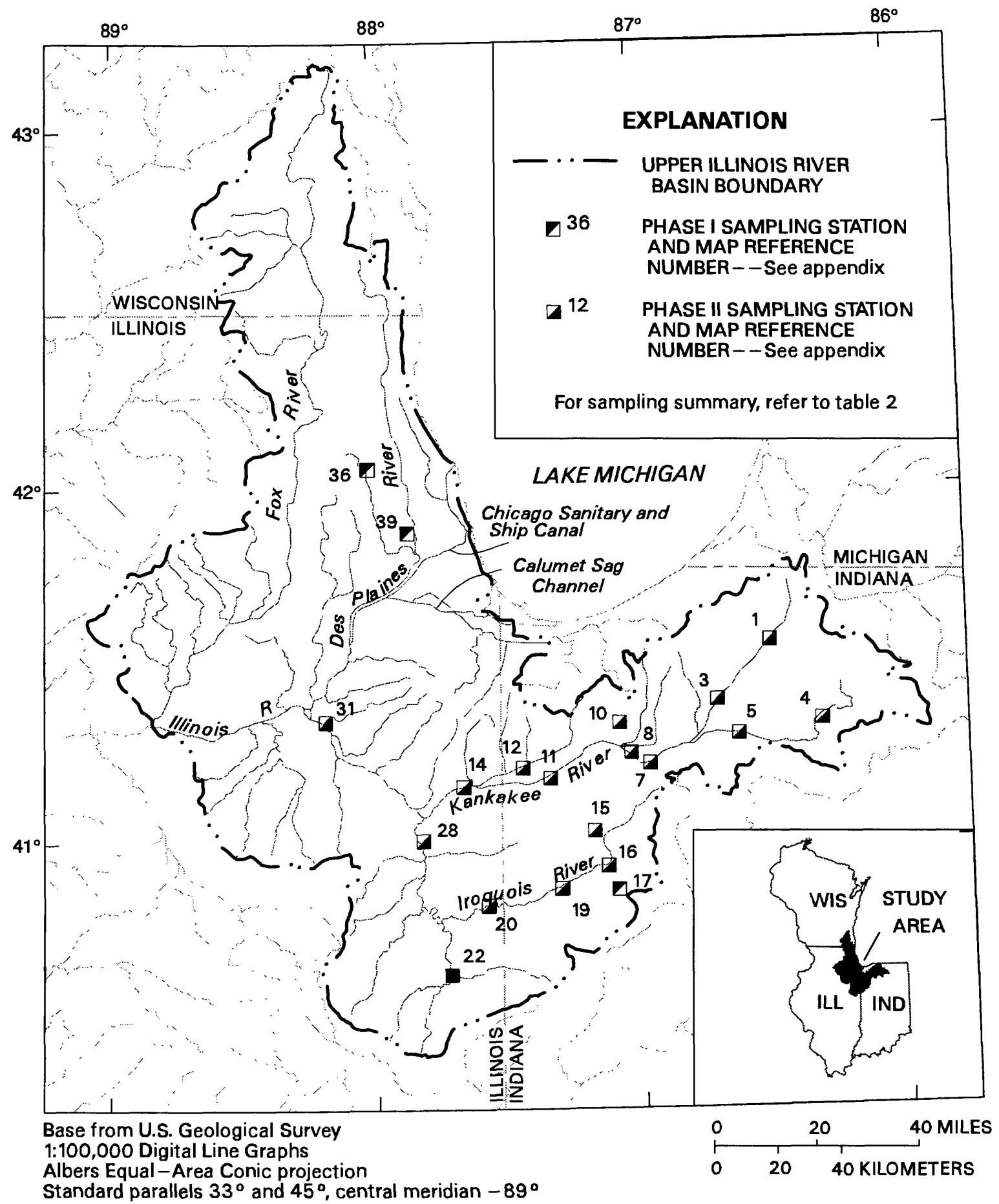

Figure 9. Sampling stations included in Phase I and Phase II pesticide in water sampling in the upper Illinois River Basin, 1988-89.

Kankakee River Basin has resulted in more arsenic associated with iron and manganese coatings, making arsenic more bioavailable. Gross and Berg (1981), however, found that whole-sediment samples from the Kankakee River between the mouth of the Iroquois
River and the city of Kankakee, Ill., contained only 1-4 percent clay-sized sediment, and concentrations of arsenic in whole-sediment samples from this same reach were lower than those from all other locations in the State included in their study (Gross and Berg, 1981, 


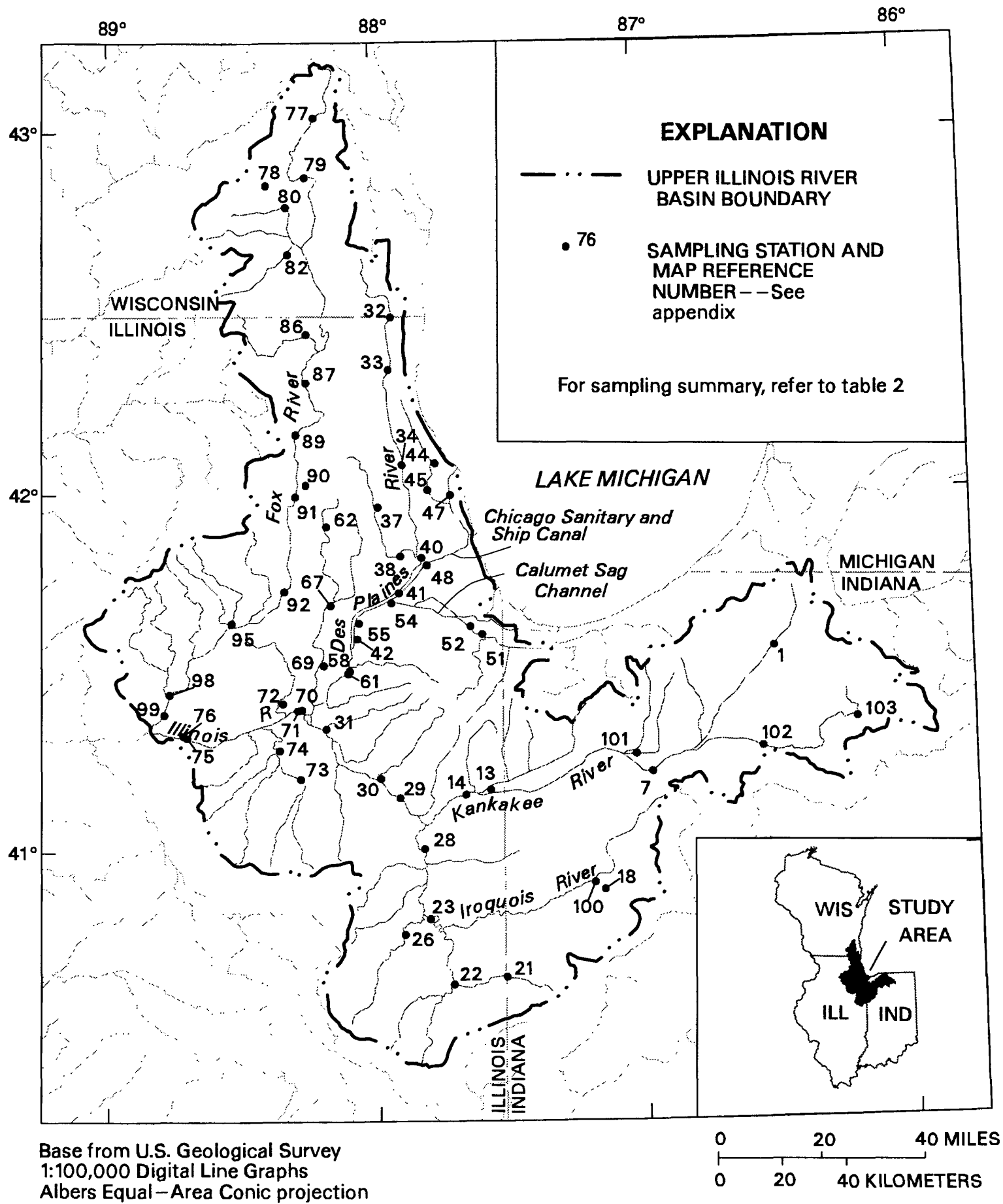

Albers Equal-Area Conic projection

Standard parallels $33^{\circ}$ and $45^{\circ}$, central meridian $-89^{\circ}$

Figure 10. Sampling stations used in the synoptic sampling of nutrients, dissolved oxygen, and fecalindicator bacteria in water in the upper Illinois River Basin.

p. 55). Although concentrations of arsenic in water are below water-quality criteria, the apparent enrichment of arsenic in biota from the upper Kankakee River warrants further study.
Concentrations of barium and strontium were highest in the Fox and Du Page River Basins and appear to be related to ground-water return flow sources. However, their distribution among the 


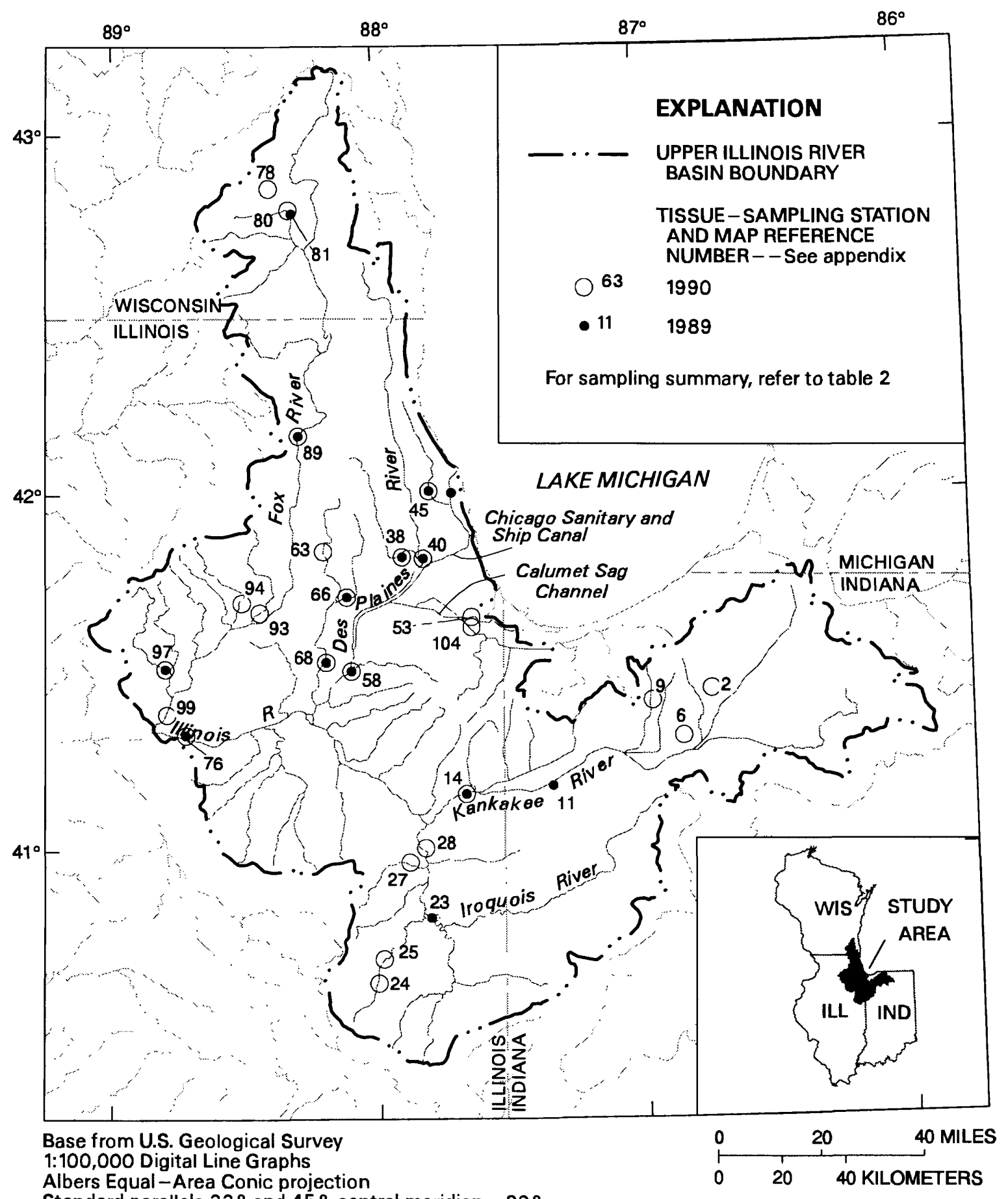

Albers Equal-Area Conic projection

Standard parallels $33^{\circ}$ and $45^{\circ}$, central meridian $-89^{\circ}$

Figure 11. Sampling stations included in synoptic surveys for fish and macroinvertebrate tissue and communities in the upper Illinois River Basin, 1989-90.

three media differs. For example, elevated strontium concentrations were observed in water and biota in the Du Page River and Fox River Basin, whereas concentrations of strontium in streambed sediment were elevated in the Fox River Basin but not in the Du Page River Basin.

Results from the synoptic sampling for trace inorganic constituents in fine-grained streambed 


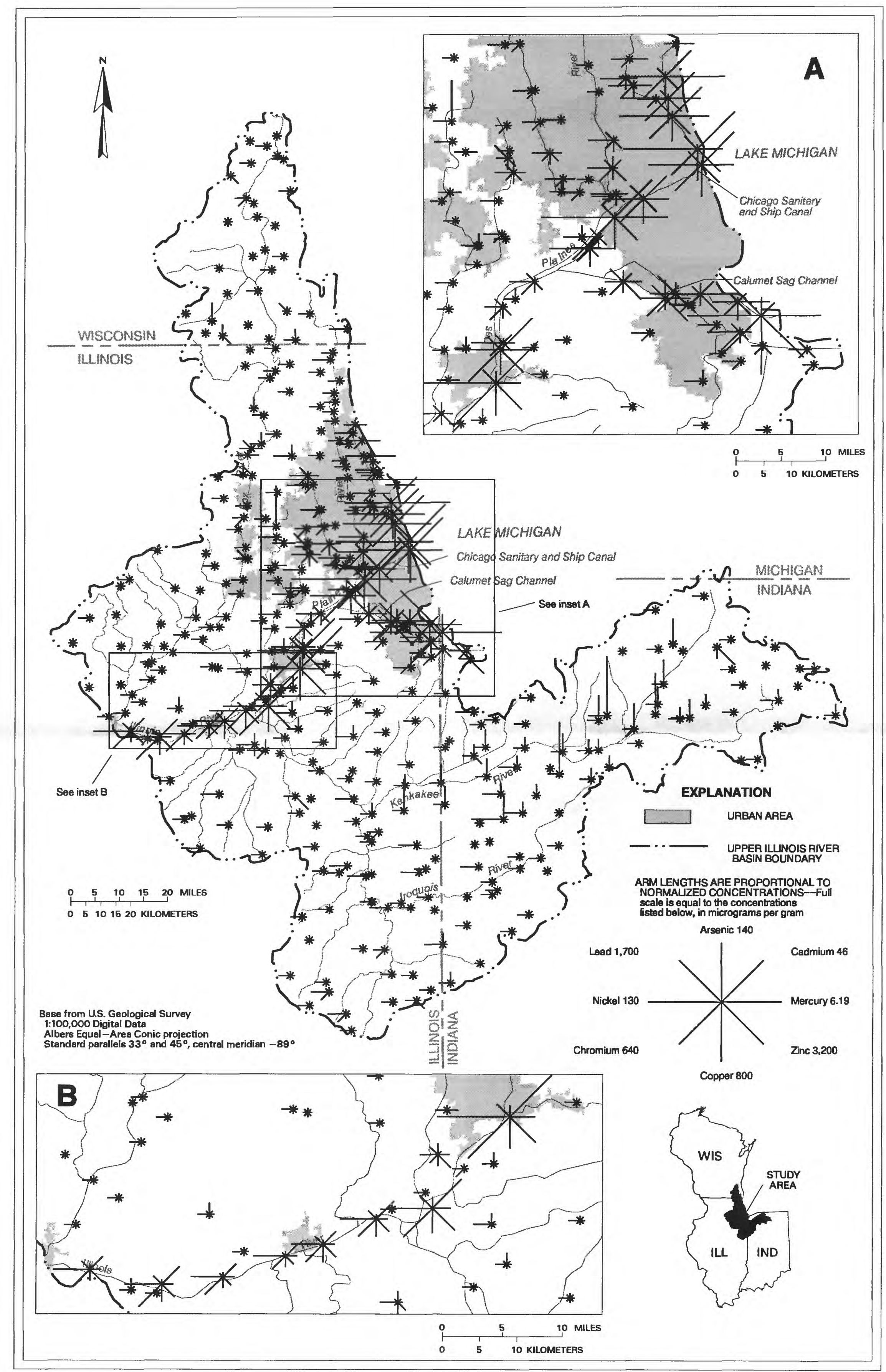

Figure 12. Normalized concentrations of selected trace inorganic constituents in the upper Illinois River Basin, 1989. 
sediments indicate two distinctive patterns of enrichment: (1) Enrichment in the Chicago metropolitan area and in streams draining the urban area, relative to rural areas (fig. 12); (2) enrichment in high-order streams (monostems), relative to low-order streams (tributaries) (fig. 13). Ratios among trace inorganic constituents were variable in samples from the Chicago urban area, indicating that element sources were variable. Ratios among trace inorganic constituents in samples from the Illinois and lower Des Plaines Rivers (downstream from Chicago) were constant, but concentrations decreased downstream indicating that the upstream sediments were diluted downstream. Ratios and concentrations of these elements in the fine-fraction streambed sediments from the Illinois River (downstream from the confluence with the Kankakee River) indicate that sediments originating from the Chicago area are diluted to 35-40 percent of original concentrations by other sources of sediment.

The exceedance probability for concentrations of chromium and lead in fine-grained streambed sediment is shown in figure 14. The curve for chromium from high-order streams breaks at $90 \mu \mathrm{g} / \mathrm{g}$. All but one of the chromium concentrations observed in low-order streams were less than $90 \mu \mathrm{g} / \mathrm{g}$. Concentrations greater than $90 \mu \mathrm{g} / \mathrm{g}$ were mainly clustered in the Chicago metropolitan area. The curves for lead concentrations for high- and low-order streams break at $40 \mu \mathrm{g} / \mathrm{g}$. Lead concentrations greater than $40 \mu \mathrm{g} / \mathrm{g}$ in fine-grained streambed sediment were mainly in the Chicago metropolitan area and near other mediumsized urban areas outside of Chicago. Correlation of the trace inorganic constituents in sediments suggests that streams contain a well-mixed variety of elements from municipal wastewater-treatment plants (combined sewer overflows in Chicago); industrial point sources; and urban runoff from streets, parking lots, and buildings.

Concentrations of cadmium, mercury, nickel, selenium, and zinc appeared to be relatively enriched in biota for rural and urban sites across the upper Illinois River Basin compared to other river basins (Fitzpatrick and others, 1995). Several types of biota (clams, crayfish, fish, plants, and snails) were used because of the difficulty of obtaining one target taxa throughout the study area. Biota from some urban sites in the basin contained high concentrations of several elements. Relatively high concentrations of cadmium, chromium, copper, lead, and nickel were observed in whole snails from the North Shore Channel, Ill. (map reference number 46), in 1989, and high concentrations of chromium and copper also were observed in Eurasian water milfoil collected from this industrial stream. Another industrial stream, the North Branch of the Chicago River at Niles, Ill. (map reference number 45), was enriched for copper and nickel in biota. Copper concentrations in water from this station have exceeded USEPA chronic water-quality criteria. Concentrations of chromium and lead also were relatively large in sago pondweed from the Little Calumet River at Calumet Park, Ill. (map reference number 53), a station located in a highly industrial area. Biota from Salt Creek at Western Springs, Ill. (map reference number 38), a stream in a residential area, contained relatively high concentrations of lead, manganese, nickel, and strontium. Total recoverable concentrations of lead in water from this station have exceeded USEPA chronic criteria.

Samples from the eight fixed-monitoring stations were analyzed for trends in concentrations of trace inorganic constituents between water years 1978 and 1991. Barium, boron, iron, manganese, and strontium concentrations in water decreased at many stations in the upper Illinois River Basin, and strontium concentrations in water increased at a number of other stations. No trends in streamflow were observed at the stations where these elements decreased. Trends in barium and strontium were probably caused by changes in ground-water sources used as water supplies in the Fox and Du Page River Basins. No trends were observed for concentrations of lead in water, which is contrary to what was expected, given the decrease in the use of leaded gasoline in the 1980's (Smith and others, 1987).

The lack of correlations among trace inorganic concentrations in biota and other media in this study emphasizes that concentrations in water and sediment cannot be used as surrogates for concentrations in biota; concentrations in biota cannot presently be estimated from concentrations in these media; and because of bioaccumulation, concentrations of trace elements in biota must be measured directly. A complex variety of chemical, physical, and biological variables affect the bioavailability of trace inorganic constituents from water and sediment. In addition, trace inorganic constituent concentrations in water are essentially instantaneous, whereas concentrations in biota may integrate the effects of water-quality conditions over time. Finally, in instances where ambient levels fall below current analytical detection limits for 


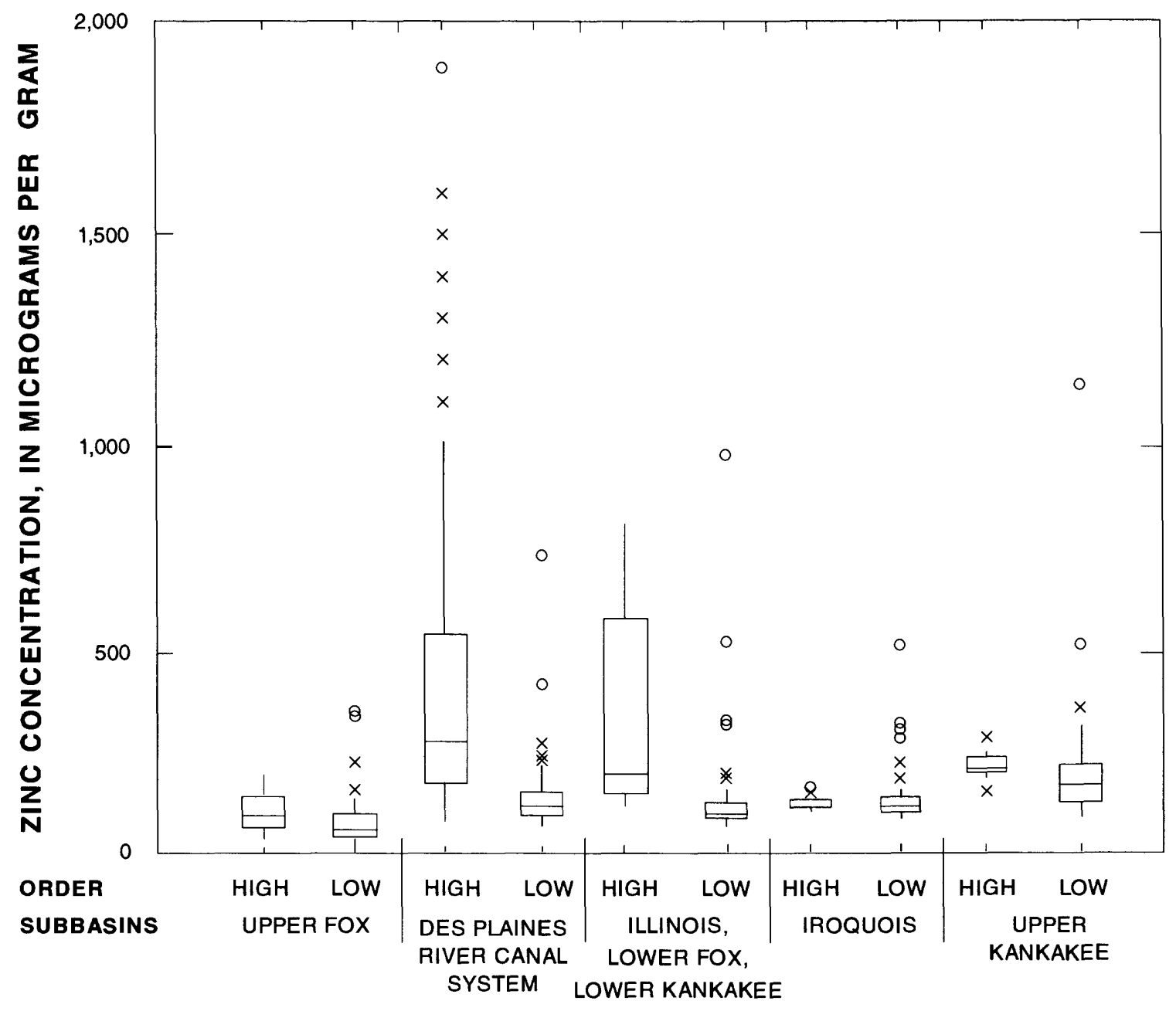

\section{EXPLANATION}

O D Data value(s) exceeding upper quartile plus 3 times the interquartile range

$\times$ - Data value(s) exceeding upper quartile plus 1.5 times the interquartile range but less than the upper quartile plus 3 times the interquartile range

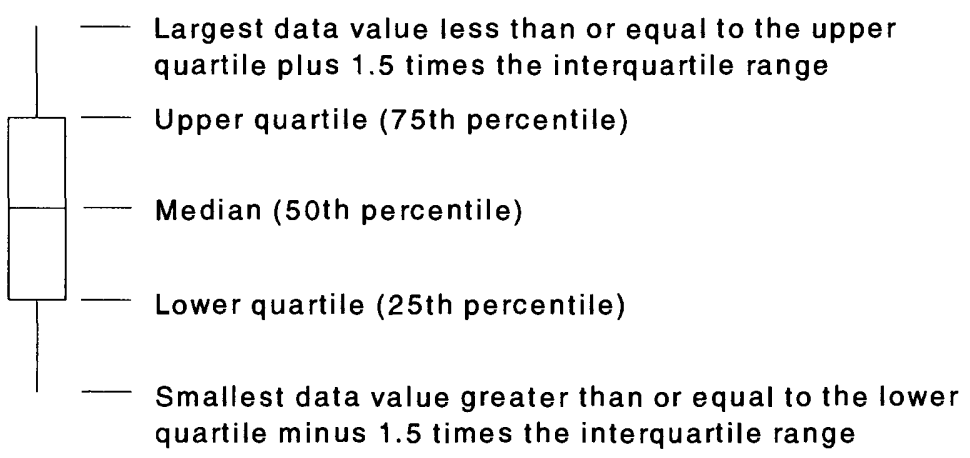

Figure 13. Fine-grained streambed-sediment zinc concentrations, by stream order, in subbasins of the upper Illinois River Basin. 

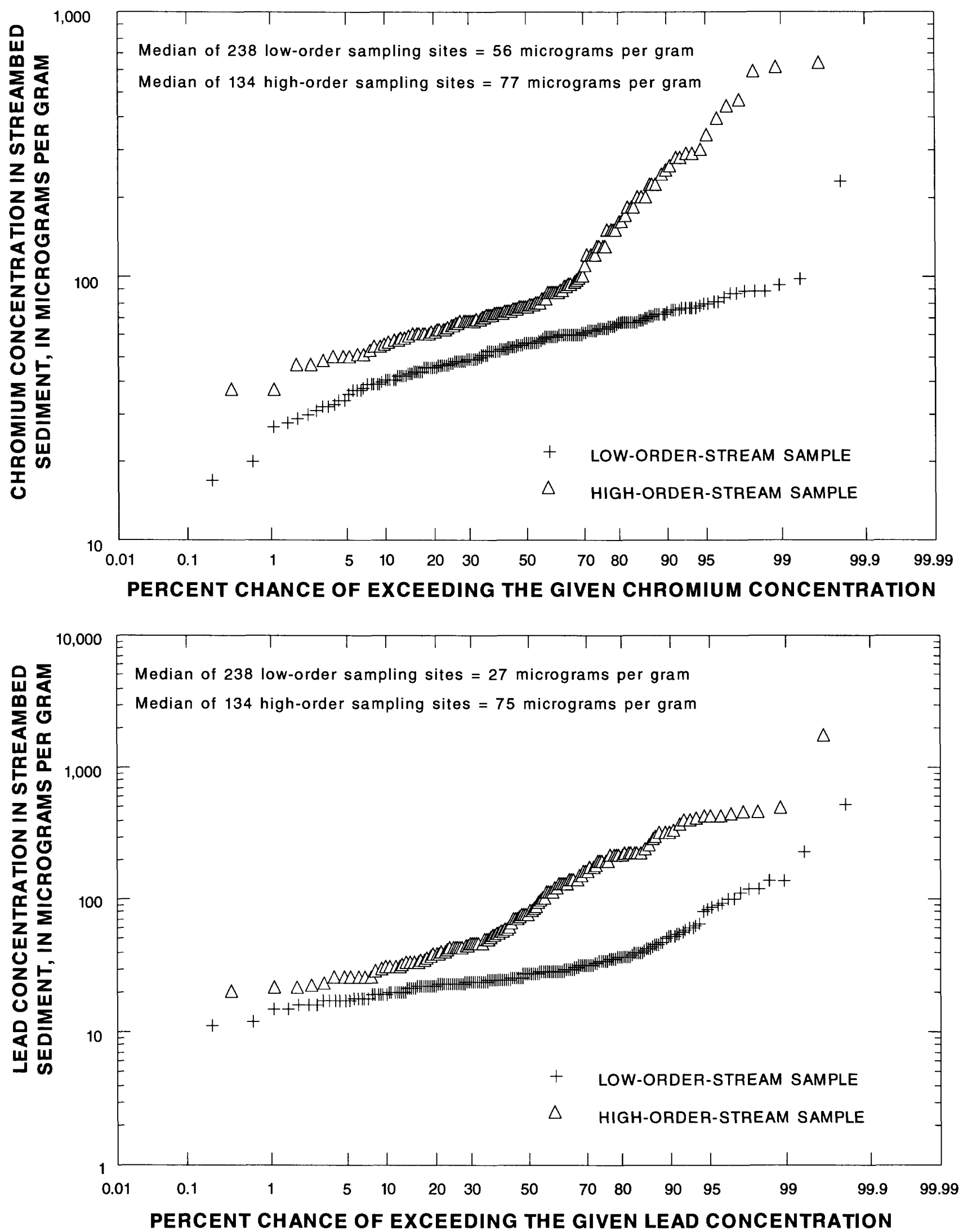

Figure 14. Exceedance probabilities for concentrations of chromium and lead in fine-fraction streambed-sediment samples from low- and high-order streams in the upper Illinois River Basin, 1989. 
water, bioconcentration above ambient levels and concentration in sediment can provide valuable waterquality information. In the upper Illinois River Basin, total recoverable and dissolved concentrations of a number of trace inorganic constituents commonly were near or below minimum reporting levels but were measurable and sometimes elevated in sediment and biota. These constituents included arsenic, selenium, and zinc. Concentrations of mercury in sediment and biota were measurable and distinctly different among sites and stations, even though a large number of censored values were observed for total recoverable and dissolved mercury in water.

\section{Organic Compounds}

Pesticides and other synthetic organic compounds (SOC's) have been detected in the water, sediment, and biota of surface waters throughout the United States. The production and use of these compounds have increased greatly over the past 50 years, and the result has been a gradual decrease in the quality of the Nation's surface-water resources (Smith and others, 1988). Pesticides and other SOC's enter surface-water systems from a variety of sources, which include direct point-source discharges of municipal and industrial wastewater, and indirect nonpointsource runoff. Many compounds with low solubility tend to bioaccumulate in organisms (Smith and others, 1988). Many pesticides and other SOC's have been shown to be potentially toxic, carcinogenic, and mutagenic (Commoner, 1979).

Agricultural areas in Illinois and neighboring States are among the most productive grain-growing regions in the world. Modern agriculture is heavily dependent on pesticides to ensure high productivity. In Illinois, in 1988, herbicides were applied to 97 percent of corn fields and 96 percent of soybean fields (Pike and others, 1990). Insecticides are applied to lower percentages of croplands. Herbicide applications in the upper Illinois River Basin are among the highest in the Nation (Koplin and others, 1994).

Pesticide loadings in urban areas also are high according to Ginsberg and Osborne (1984), who estimate that 75-90 percent of households apply pesticides. Home owners, land-management agencies, and other governmental agencies apply herbicides and insecticides at rates as high as $10 \mathrm{lb} / \mathrm{acre}$. Therefore, extensive surface-water contamination by pesticides is possible in urban areas in the basin.
Extensive surface-water contamination by nonagricultural SOC's is possible in and near the large urban and industrial areas of Chicago. The major sources to streams of these SOC's are industrial effluent and municipal wastewater discharges (Moore and Ramamoorthy, 1984).

Analysis of historical data was utilized as a first step in describing the presence and extent of SOC's in the upper Illinois River Basin. Statistical analyses of historical data were limited because the data were combined from several sources, and collected and analyzed using unknown procedures. Analysis indicated that water-column sampling should be limited to relatively soluble (hydrophilic) compounds and sediment sampling to relatively insoluble (hydrophobic) compounds. This result guided the design of the organics sampling program of the NAWQA pilot study.

Intensive data-collection activities performed as part of the NAWQA study included pesticide sampling at four stations in 1988 and 1989. Two stations were on streams draining urban areas, and two stations were on streams draining agricultural areas. Bromacil, diazinon, malathion, prometone, and simazine were identified as primarily urban-related because they were detected more frequently or at higher concentrations from urban stations than from agricultural stations (figs. 15 and 16). Alachlor, atrazine, cyanazine, metolachlor, and metribuzin were detected more frequently or at higher concentrations at agricultural stations. However, several of the organic compounds typically associated with agriculture were frequently detected in the urban areas as high concentrations. Concentrations of atrazine exceeded the $\mathrm{MCL}^{2}$ $(3 \mu \mathrm{g} / \mathrm{L})$ for drinking water in agricultural and urban land-use areas.

Sixty-eight herbicide samples were collected at 17 stations in the primarily agricultural Kankakee and Iroquois River Basins in 1990. Atrazine and metolachlor were detected in all samples. The atrazine breakdown products, desethylatrazine and desisopropylatrazine, were detected in 100 and 94 percent of samples, respectively. The data indicate that atrazine concentrations exceeded the MCL during runoff periods. The estimated total atrazine load from the Iroquois River Basin was less than 1 percent of the estimated amount of atrazine applied to the land. The

\footnotetext{
${ }^{2}$ Maximum contaminant level: enforceable, health-based National Primary Drinking Water Standards of the U.S. Environmental Protection Agency.
} 


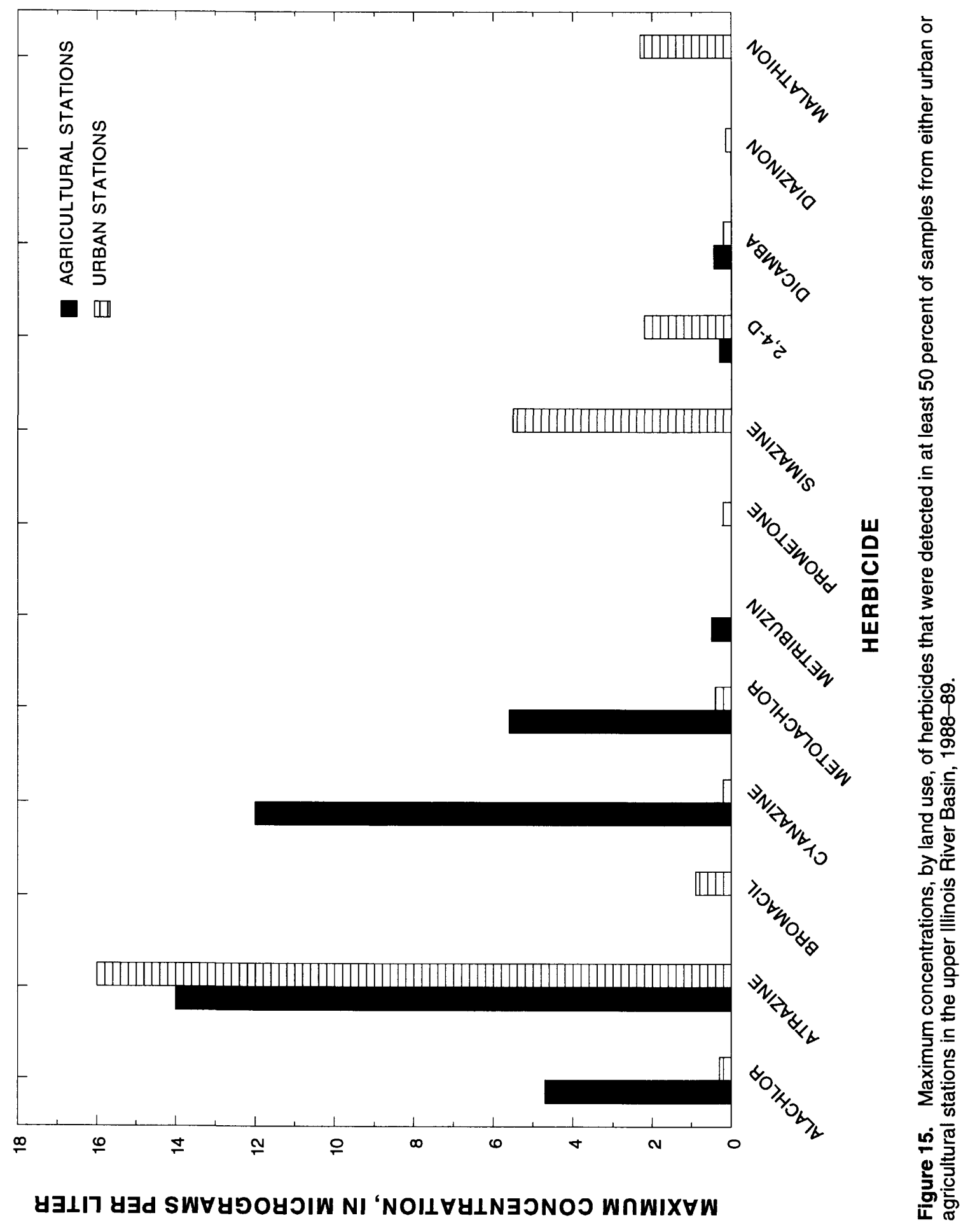




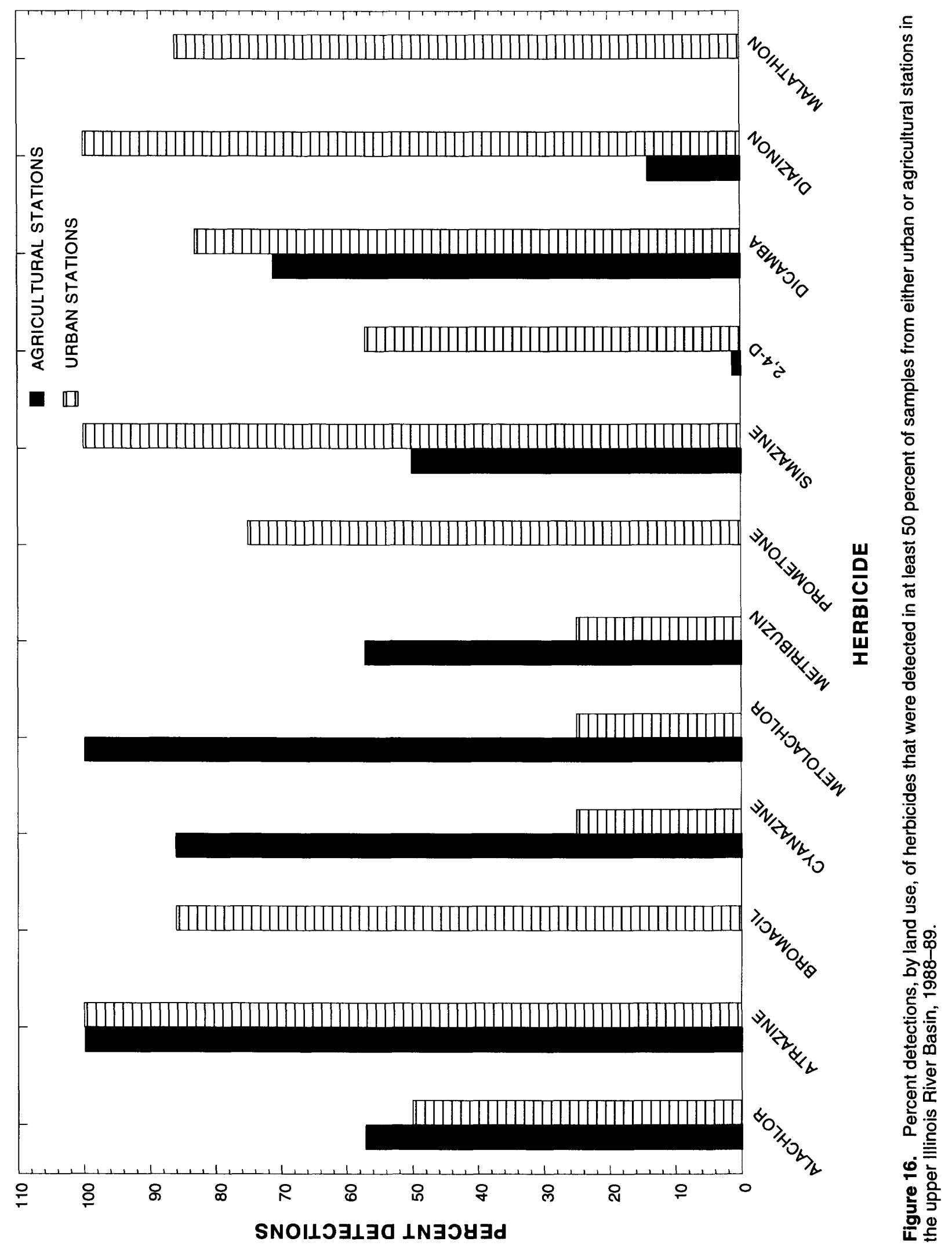


time of year and magnitude of the runoff were the most important factors for estimating atrazine concentrations in streams. High correlation coefficients among most of the triazine herbicides indicate cooccurrence in the environment-when one triazine herbicide is detected, other triazine herbicides also are likely to be detected.

A low-flow synoptic survey for volatile organic compounds (VOC's) and semivolatile organic compounds (SVOC's) in water was conducted in 1988. The stations where two or more volatile organic compounds were detected are shown in figure 17. Results indicate that chloroform was the most commonly detected compound present in samples from 13 of 31 stations (42 percent). Commonly, chloroform is found in waters receiving chlorinated effluent. The next most commonly detected compounds, tetrachloroethylene and 1,1,1-trichloroethane, each were detected in samples from 9 of 31 stations ( 29 percent). A total of 21 different VOC's and one SVOC was detected at least once. All sites where more than one compound was detected were within the vicinity of a point source. Detections at two sites in the Chicago metropolitan area accounted for 37 percent ( 28 of 76 ) of the VOC detections. One exceedance of a drinking-water MCL was detectedtetrachloroethylene concentration was $5.5 \mathrm{mg} / \mathrm{L}$ at the Des Plaines River at Lockport, Ill. The detection of VOC's in stream waters is noteworthy; VOC's are not usually detected in stream water because these compounds volatilize out of the system rapidly.

Monitoring of VOC concentrations in water at two NAWQA fixed-monitoring stations was performed from June 1988 to March 1990. VOC's were detected, occasionally, at high concentrations. Results indicate three exceedances of MCL's during this time period.

Phenolic compounds were detected most frequently in water from the Des Plaines River Basin; 251 of the 406 total detections (62 percent) were observed in the upper Illinois River Basin. Pointsource discharges, such as wastewater-treatment plant and industrial effluents, are more predominant in the Des Plaines River Basin than in other subbasins of the upper Illinois River Basin. Concentrations of phenolic compounds were significantly different among the Des Plaines, Kankakee, and Fox River Basins (fig. 18). Phenolic compound concentrations at stations located within each basin were not significantly different, except in the Des Plaines River Basin, where source or natural spatial variability may be the cause for a significant difference among some stations. Median phenolic compound concentrations, measured in samples taken during the Metropolitan Water Reclamation District of Greater Chicago (MWRDGC) 1989 survey, decreased with distance downstream from Chicago. Phenolic compound concentrations never exceeded the generaluse and secondary-contact standards of 100 and $300 \mu \mathrm{g} / \mathrm{L}$, respectively.

Pentachlorophenols were the most extensively used of the chlorophenolic compounds in the basin (Smith and others, 1988). The use of pentachlorophenol on nonwood products was banned by the IEPA in 1987. Concentrations of pentachlorophenols observed in the environment have been decreasing since the ban. Pentachlorophenols were detected most frequently in the Des Plaines River Basin with concentrations as high as $180 \mu \mathrm{g} / \mathrm{L}$ at the North Branch Chicago River at Niles, Ill. (map reference number 45). Pentachlorophenol concentrations detected at the Illinois River at Marseilles, Ill. (map reference number 76), from 1981 to 1992 show a decrease in concentrations beginning in 1987 (fig. 19); this was most likely associated with the ban. Pentachlorophenol concentration in water from the study area never exceeded the $1-\mu \mathrm{g} / \mathrm{L}$ drinkingwater standard.

A survey of the presence and extent of SVOC's in streambed sediment was conducted in 1987, and a synoptic survey was conducted in 1989. Results from quality-assurance sampling indicate that data were adequate as a general indication of the detection of compounds but not for quantitative comparison among stations (Sullivan and others, in press). Results indicate that stations in the Chicago metropolitan area had the most detections of SVOC's. Of the 17 stations at which 10 or more compounds were detected in 1989, 14 were located in the Des Plaines River subbasin and 1 was downstream on the Illinois River mainstem. The remaining two stations were in urbanized areas of the Fox and Du Page Rivers (fig. 20). The most commonly detected compounds included the polycyclic aromatic hydrocarbons (PAH's), phenanthrene, fluoranthene, pyrene, fluorene, benzo $(a)$ anthracene and benzo $(g, h, i)$ perylene, and the plasticizer bis(2-ethylhexyl)phthalate. As with VOC's in water, each of these stations was located within $2 \mathrm{mi}$ downstream from point sources.

Tissue samples from whole fish were collected and analyzed for organochlorines and PAH's in 1989 and 1990. A biodegradation-resistant metabolicbreakdown product of the organochlorine pesticide dichloro-diphenyl-trichloroethane (DDT), $p, p^{\prime}$-DDE, 


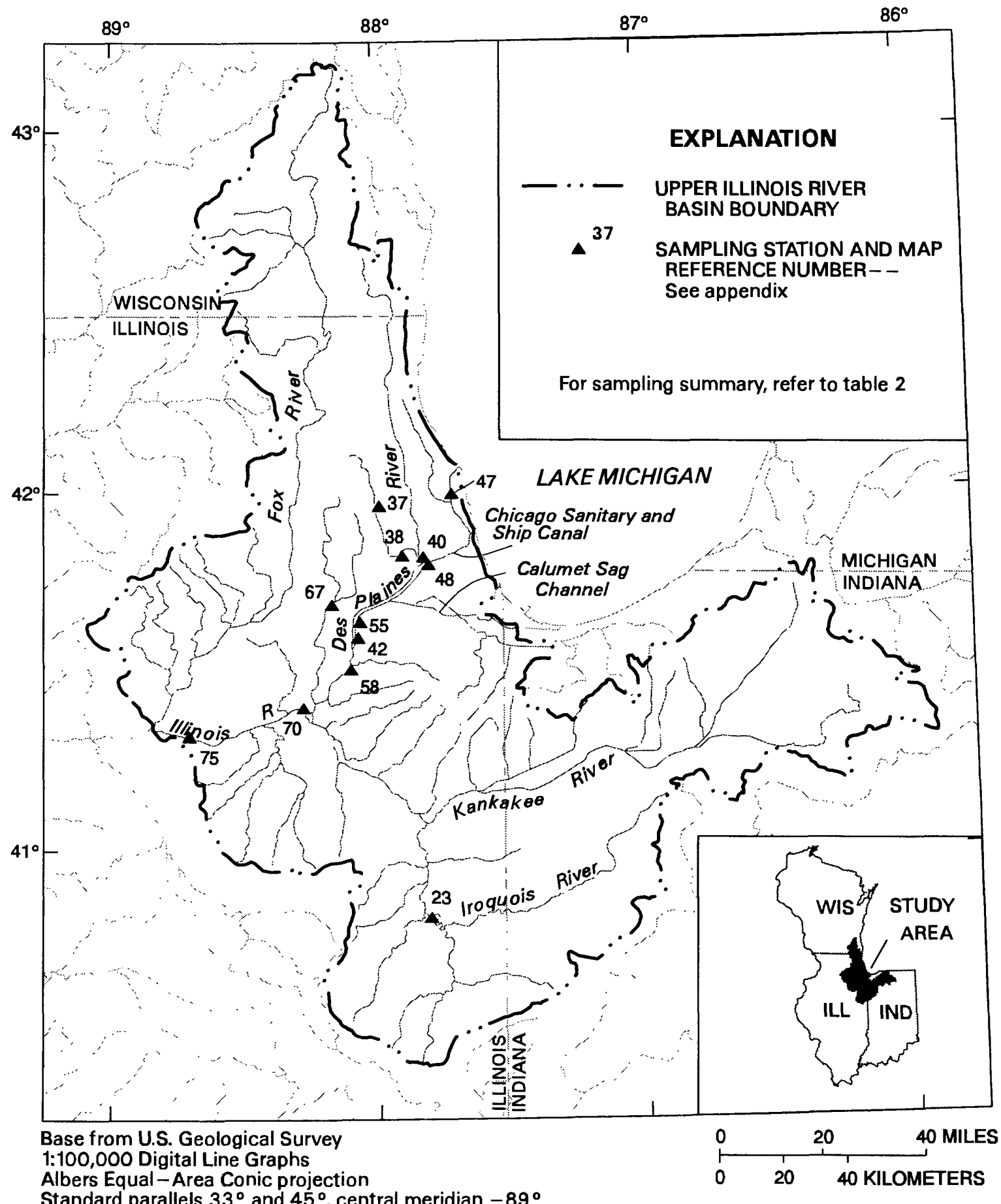

Standard parallels $33^{\circ}$ and $45^{\circ}$, central meridian $-89^{\circ}$

Figure 17. Location of stations where two or more volatile organic compounds were detected during a 1988 low-flow synoptic survey in the upper Illinois River Basin. 


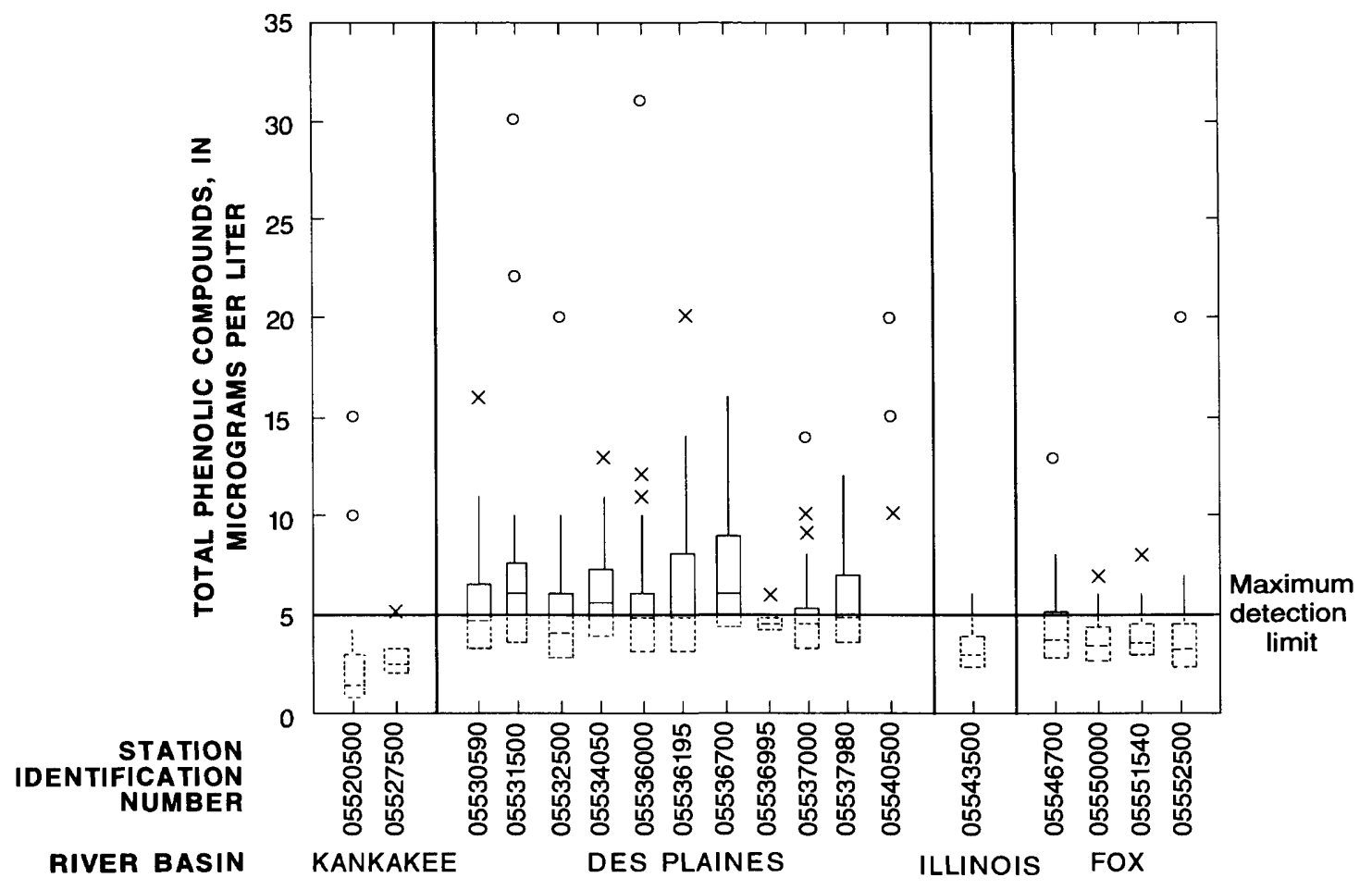

\section{EXPLANATION}
- D Data value(s) exceeding upper quartile plus 3 times the interquartile range
$\times$ - Data value(s) exceeding upper quartile plus 1.5 times the interquartile range but less than the upper quartile plus 3 times the interquartile range

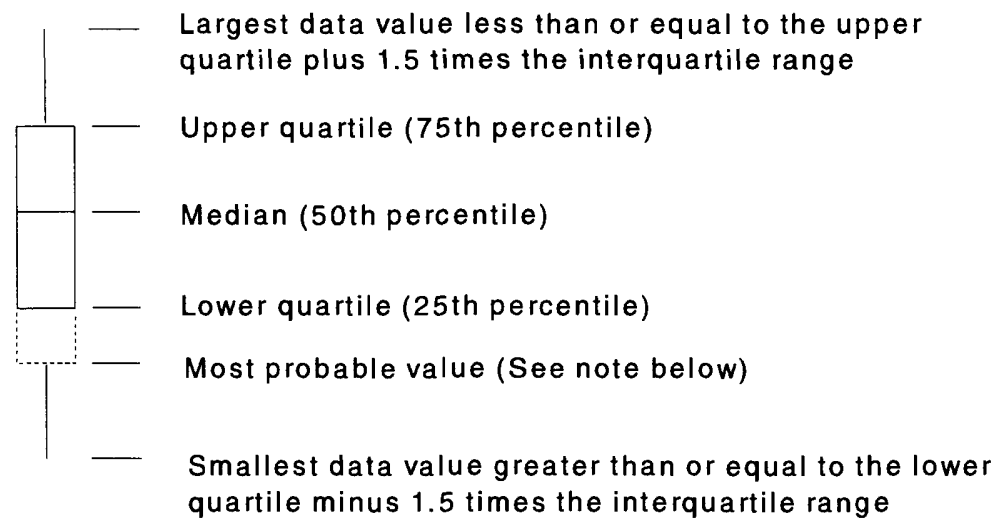

NOTE: MOST PROBABLE VALUE--Tukey plots for stations having constituents with multiple detection limits were modified to display quartiles estimated by fitting the data to a log-normal distribution and applying a procedure outlined in Helsel and Cohn (1988)

Figure 18. Summary of available data for total phenolic compound concentrations at stations in the upper Illinois River Basin, water years 1987-90. 


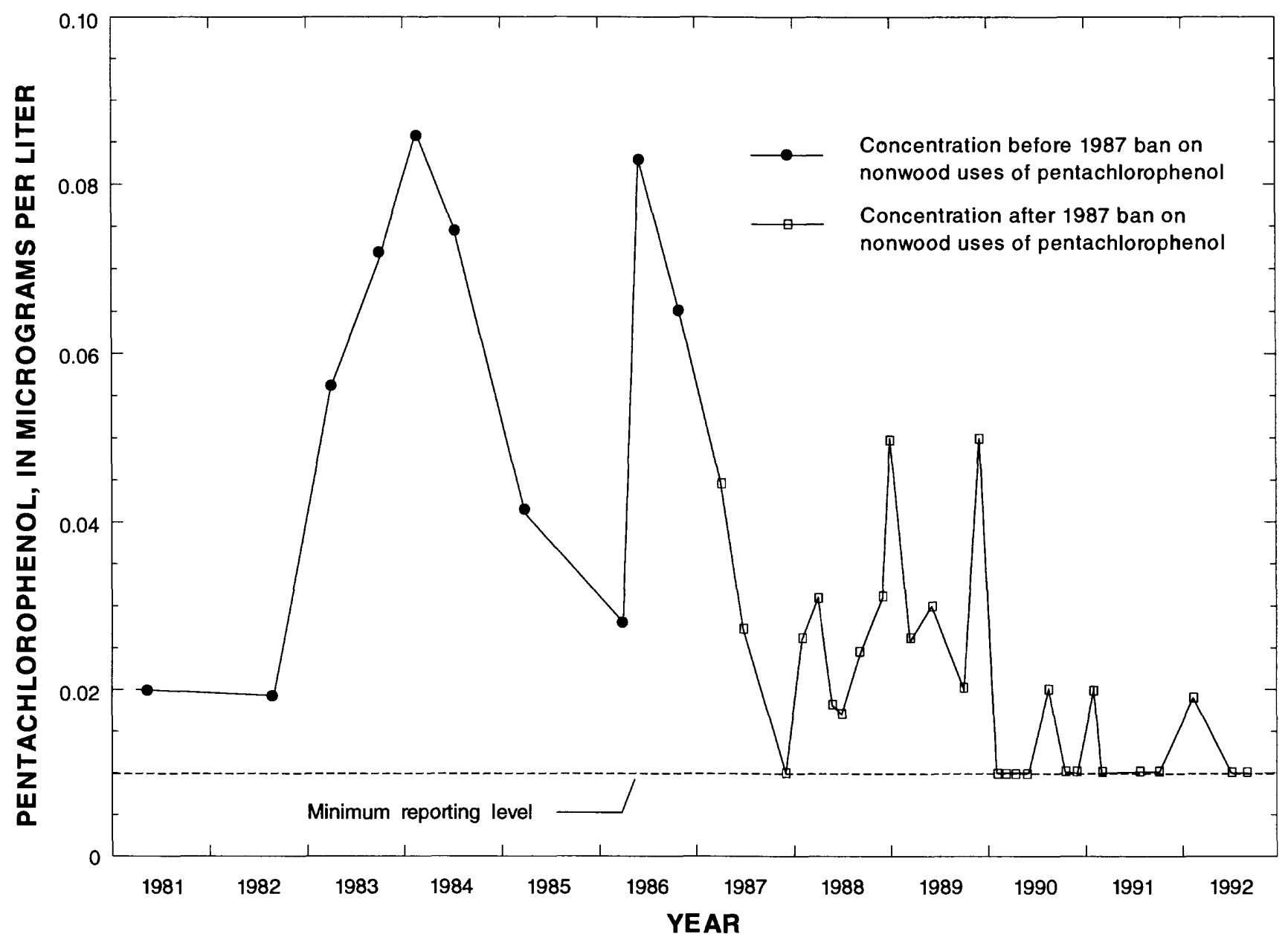

Figure 19. Concentrations of pentachlorophenol at the Illinois River at Marseilles, III. (05543500), water years $1981-92$.

was the most commonly detected compound in 1989 and 1990. Concentrations of polychlorinated biphenyls (PCB's), $p, p$ '-DDE, $p, p$ '-DDD, and dieldrin were the highest (table 3). Correlations were observed among the chlordane components, among the DDT breakdown products, and between these two groups of compounds (table 4). Dieldrin was correlated to chlordane components but was not correlated to DDT breakdown products. Some correlation was observed between most of the compounds and the lipid content of the sample. Concentrations were lower in fish fillets than in whole fish. Lipid content is lower in fillets than in whole fish, indicating the strong tendency of these compounds to accumulate in the lipid portion of the fish. Normalizing organic-compound concentrations in whole fish for lipids reduced the differences between concentrations in whole fish and fillets.
Numerous exceedances of the National Academy of Science (1972) standards for protection of predatory animals were detected in fish from the upper Illinois River Basin; a total of 16 exceedances for chlordane and 8 exceedances for dieldrin, when 1989 and 1990 data were combined. Nine fillet samples were collected in 1989 and exceedances of USEPA (1992a) fish-tissue concentrations criteria in relation to the protection of human health were observed for $p, p^{\prime}$-DDE in nine of nine fillets and for dieldrin in six of nine fillets.

Comparisons between SOC's in fine-grained streambed sediment and biota were limited to analyses of cooccurring compounds. There were 37 total detections of organochlorines in biota and 23 in streambed sediment, of which 14 compounds were detected in both media at a station. Total chlordane, PCB's, $p, p$ '-DDE, and dieldrin each had 2-4.5 times 


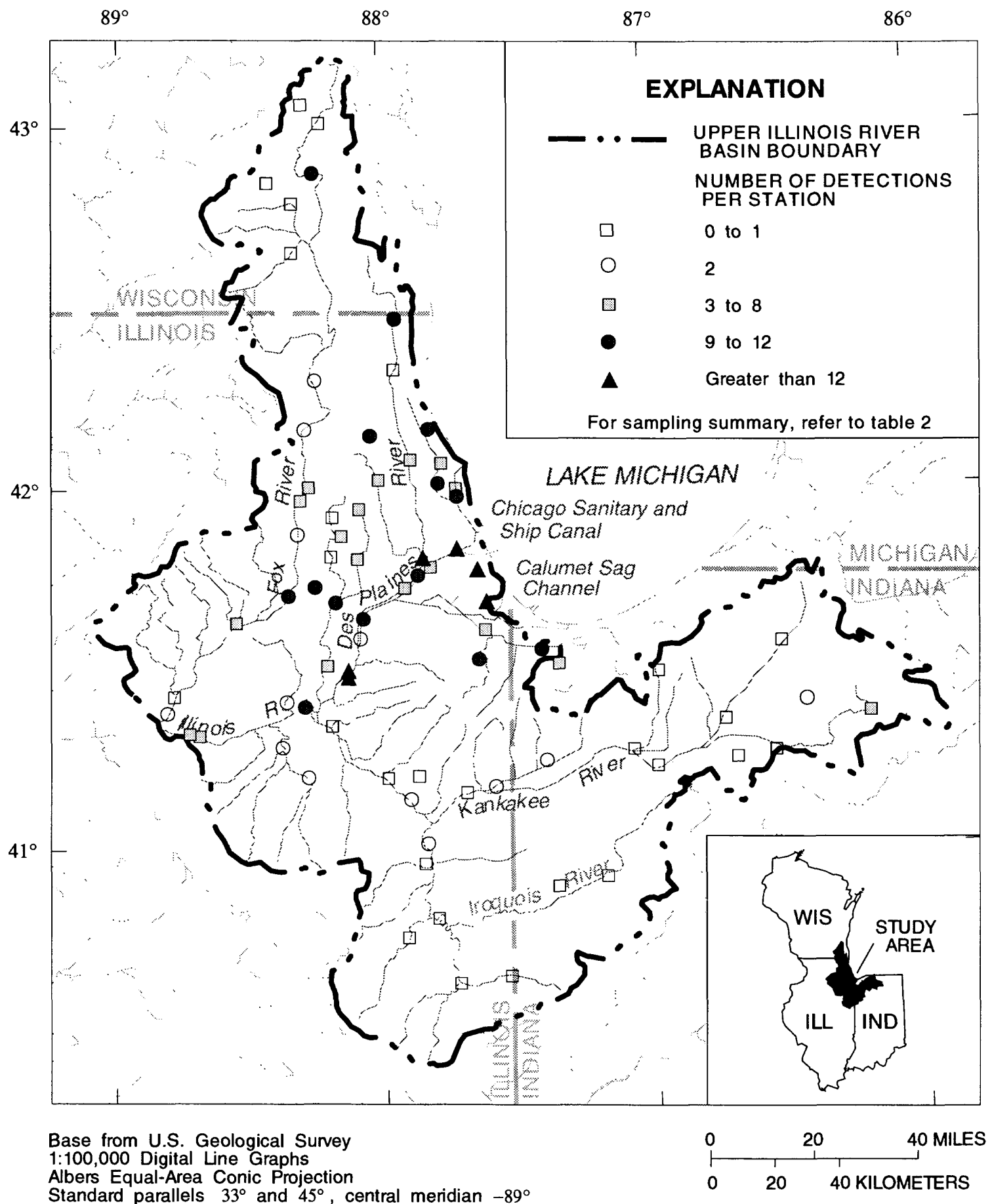

Figure 20. Spatial distribution of synthetic organic compounds in streambed sediment in the upper Illinois River Basin, 1989. 
Table 3. Summary of concentrations of organochlorine compounds in whole-fish samples from the upper Illinois River Basin, 1989-90 (from Sullivan and others, in press)

[Data presented are for whole fish collected as part of the upper Illinois River Basin NAWQA project. Concentrations are in micrograms per gram, wet weight. NAWQA, National Water-Quality Assessment; NCBP, National Contaminant Biomonitoring Program; NSCRF, National Study of Chemical Residues in Fish; DDT, dichloro-diphenyl-trichloroethane; <, less than; NR, not reported; DDD, dichloro-diphenyl-dichloroethane; DDE, dichloro-diphenyl-trichloroethylene; PCB, polychlorinated biphenyl]

\begin{tabular}{|c|c|c|c|c|c|}
\hline \multirow[b]{3}{*}{ Compound } & \multicolumn{3}{|c|}{ Upper Illinois River Basin } & \multirow{3}{*}{$\begin{array}{l}\text { NCPB } \\
\text { mean }^{1}\end{array}$} & \multirow{3}{*}{$\begin{array}{c}\text { NSCRF } \\
\text { mean }^{2} \\
\end{array}$} \\
\hline & \multicolumn{3}{|c|}{ NAWQA } & & \\
\hline & Maximum & Mean & Median & & \\
\hline$o, p^{\prime}-\mathrm{DDT}$ & 0.05 & $<0.01$ & $<0.01$ & NR & NR \\
\hline$p, p^{\prime}-\mathrm{DDT}$ & .07 & $<.01$ & $<.01$ & 0.03 & NR \\
\hline$o, p$ '-DDD & .24 & .04 & .01 & NR & NR \\
\hline$p, p^{\prime}-\mathrm{DDD}$ & 1.5 & .17 & .03 & .06 & NR \\
\hline$o, p^{\prime}-\mathrm{DDE}$ & $<.01$ & $<.01$ & $<.01$ & NR & NR \\
\hline$p, p^{\prime}-\mathrm{DDE}$ & .84 & .15 & .08 & .19 & 0.30 \\
\hline $\mathrm{DDT}+\mathrm{DDE}+\mathrm{DDD}$ & 2.56 & .37 & .15 & .26 & NR \\
\hline Total PCB's & 3.3 & .73 & .38 & .39 & 7.6 \\
\hline Hexachlorobenzene & .02 & $<.01$ & $<.01$ & NR & .006 \\
\hline$\alpha$-Hexachlorocyclohexane & $<.01$ & $<.01$ & $<.01$ & $<.01$ & .002 \\
\hline B-Hexachlorocyclohexane & $<.01$ & $<.01$ & $<.01$ & NR & NR \\
\hline$\gamma$-Hexachlorocyclohexane (lindane) & $<.01$ & $<.01$ & $<.01$ & $<.01$ & .003 \\
\hline$\delta$-Hexachlorocyclohexane & $<.01$ & $<.01$ & $<.01$ & NR & NR \\
\hline cis-Chlordane & .20 & .05 & .02 & .03 & .021 \\
\hline trans-Chlordane & .27 & .03 & .02 & .02 & .017 \\
\hline cis-Nonachlor & .04 & .01 & $<.01$ & .02 & .009 \\
\hline trans-Nonachlor & .11 & .01 & $<.01$ & .03 & .017 \\
\hline Oxychlordane & .02 & $<.01$ & $<.01$ & .01 & .005 \\
\hline Heptachlor epoxide & .03 & .01 & $<.01$ & .01 & .002 \\
\hline Chlordane-related compounds & .63 & .14 & .10 & .12 & NR \\
\hline Toxaphene & $<.01$ & $<.01$ & $<.01$ & .14 & NR \\
\hline Dieldrin & .52 & .07 & .05 & .04 & .028 \\
\hline Endrin & $<.01$ & $<.01$ & $<.01$ & $<.01$ & .002 \\
\hline Mirex & $<.01$ & $<.01$ & $<.01$ & $<.01$ & .004 \\
\hline Kepone & $<.01$ & $<.01$ & $<.01$ & NR & NR \\
\hline Dicofol & $<.01$ & $<.01$ & $<.01$ & NR & .001 \\
\hline Octachlorostyrene & $<.01$ & $<.01$ & $<.01$ & NR & .002 \\
\hline
\end{tabular}

\footnotetext{
${ }^{1}$ From Schmitt and others, 1990.

${ }^{2}$ From U.S. Environmental Protection Agency, 1992a.
}

as many detections in samples from biota as from finegrained streambed sediment. Total detections of PAH's in biota and sediment were 39 and 41 , respectively, of which 24 compounds were detected in both media at a station.

Future studies to determine the presence and extent of current-generation herbicides in the upper
Illinois River Basin would benefit from more precise information on pesticide use. Most of the information currently available is based roughly on use estimates of statewide average application rates. Sampling for agricultural pesticides also should be performed over a period of several years because rainfall timing and intensity can vary considerably, and important runoff 
Table 4. Correlation coefficients of compounds detected in over 50 percent of fish samples in the upper Illinois River Basin, 1989-90 (from Sullivan and others, in press)

[DDE, dichloro-diphenyl-trichloroethylene; DDD, dichloro-diphenyl-dichloroethane; only those with $\mathrm{p} \leq 0.05$ are shown, those with $\mathrm{p}>0.05$ are indicated with --]

$\begin{array}{lllllll}\text { Compound } & \text { trans-Nonachlor } & \text { cis-Chlordane } & p, p^{\prime}-D D E & \text { Dieldrin } & \text { p, } p^{\prime} \text {-DDD } & \text { Lipid content }\end{array}$

\begin{tabular}{|c|c|c|c|c|c|c|c|c|c|}
\hline \multicolumn{10}{|c|}{1989 Samples } \\
\hline trans-Nonachlor & 1.00 & & & & & & & & \\
\hline cis-Chlordane & .90 & & 1.00 & & & & & & \\
\hline$p, p^{\prime}-\mathrm{DDE}$ & .66 & & .69 & 1.00 & & & & & \\
\hline Dieldrin & .58 & & .53 & -- & & 1.00 & & & \\
\hline$p, p^{\prime}-\mathrm{DDD}$ & .54 & & .55 & .66 & & .45 & 1.00 & & \\
\hline Lipid Content & .80 & & .81 & .64 & & .67 & .48 & 1.00 & \\
\hline Compound & $\begin{array}{c}\text { Heptachlor } \\
\text { epoxide }\end{array}$ & $\begin{array}{c}\text { trans- } \\
\text { Chlordane }\end{array}$ & $\begin{array}{c}\text { trans- } \\
\text { Nonachlor }\end{array}$ & $\begin{array}{c}\text { cis- } \\
\text { Chlordane }\end{array}$ & $p, p^{\prime}-\mathrm{DDE}$ & Dieldrin & $0, p^{\prime}-\mathrm{DDD}$ & $p, p^{\prime}-\mathrm{DDD}$ & $\begin{array}{c}\text { Lipid } \\
\text { content }\end{array}$ \\
\hline \multicolumn{10}{|c|}{1990 Samples } \\
\hline Heptachlor epoxide & 1.00 & & & & & & & & \\
\hline trans-Chlordane & -- & 1.00 & & & & & & & \\
\hline trans-Nonachlor & .36 & .88 & 1.00 & & & & & & \\
\hline cis-Chlordane & -- & .95 & .88 & 1.00 & & & & & \\
\hline$p, p^{\prime}-\mathrm{DDE}$ & -- & .78 & .79 & .82 & 1.00 & & & & \\
\hline Dieldrin & .61 & .62 & .69 & .54 & -- & 1.00 & & & \\
\hline$o, p^{\prime}-\mathrm{DDD}$ & -- & .71 & .65 & .77 & .80 & -- & 1.00 & & \\
\hline$p, p^{\prime}-\mathrm{DDD}$ & -- & .73 & .67 & .83 & .86 & -- & .92 & 1.00 & \\
\hline Lipid content & -- & .82 & .73 & .79 & .68 & .50 & .55 & .60 & 1.00 \\
\hline
\end{tabular}

events may not be sampled. Sampling over several years would yield data from various hydrologic conditions, give a better indication of how often pesticide concentrations exceed health advisories, and give better information on loading and transport.

Concentrations of VOC's and SVOC's generally are low in the water column, often below the detection limit, and, as a result, few statistical analyses can be made. Locating sources of these compounds and monitoring outputs, if possible, and then modeling fate and transport to determine the possible outcomes of the actual loadings to the streams could be of great value in understanding the processes that control the concentration of these compounds in water.

Streambed sediment and biota sampling have the greatest potential value in determining distributions and concentrations of relatively insoluble SOC's. Although biota usually bioaccumulate compounds at higher concentrations, streambed-sediment samples generally are analyzed for a wider variety of compounds.

\section{Nutrients, Dissolved Oxygen, and Fecal-Indicator Bacteria}

The IEPA identified widespread violations of water-quality standards for fecal coliform, ammonia nitrogen, and dissolved oxygen in their 1979 waterquality-management plan (Illinois Environmental Protection Agency, 1979) as major water-quality issues in Illinois. This same report indicated that nonpoint sources are sufficient to cause the water-quality problems observed at most monitoring sites. More recent reports identified increased nutrients and decreased dissolved oxygen concentrations as primary causes for streams that were not fully supporting their designated uses (Illinois Environmental Protection Agency, 1988, p. 70). Point sources accounted for about 24 percent of the streams not fully supporting their designated uses, whereas agricultural, urban, and mining nonpoint sources accounted for about 55 percent of the streams not fully supporting their designated uses (Illinois Environmental Protection Agency, 1988, p. 70). 
Data collected as part of the Survey's NAWQA program were utilized to describe the presence, spatial distribution, and temporal variability of nutrients, dissolved oxygen, and fecal-indicator bacteria in the upper Illinois River Basin in Illinois, Indiana, and Wisconsin from 1987 to 1990 . Data from water years 1978-86, collected by the IEPA, were used in conjunction with USGS data to assess long-term trends in constituent concentrations. Five nutrient forms - total nitrogen, dissolved nitrite plus nitrate, total ammonia, total organic nitrogen, and total phosphorus-were used to represent nutrient conditions in the upper Illinois River Basin.

Approximately 74,730 tons of nitrogen and 3,850 tons of phosphorus are transported out of the upper Illinois River Basin each year in the Illinois River. Sources of nutrient inputs to the upper Illinois River Basin included wastewater-treatment plants, commercial and industrial sources, fertilizer application, atmospheric deposition, ground water, Lake Michigan withdrawals and diversions, soil erosion, and plant material. These sources supplied an estimated 247,000 tons of nitrogen and 94,000 tons of phosphorus to the upper Illinois River Basin each year.

The Des Plaines River Basin contributed approximately 41 percent of the total nitrogen load to the upper Illinois River Basin, whereas the Kankakee and Fox River Basins contributed about 39 and 13 percent of the total load, respectively (fig. 21). About 30 percent of the total nitrogen load in the upper Illinois River Basin was measured in the Chicago Sanitary and Ship Canal at Romeoville, Ill. (map reference number 55).

During low-flow conditions, almost all of the total nitrogen load was observed in the Des Plaines River Basin. Most of this load was attributed to the Chicago Sanitary and Ship Canal, which receives substantial inputs of wastewater effluents. The Chicago Sanitary and Ship Canal also transported the majority of ammonia and phosphorus loads during low-flow conditions.

During low-flow conditions in the upper Illinois River Basin, most of the load transported out of the basin was from the Des Plaines River Basin and primarily results from wastewater-treatment-plant effluent from the Chicago Sanitary and Ship Canal. The Chicago Sanitary and Ship Canal also was observed to carry the majority of ammonia and phosphorus loads during low-flow conditions.
Nutrient concentrations in the upper Illinois River Basin generally were higher than concentrations typically found in natural waters (Puckett, 1994; Mueller and Helsel, 1996). Nutrient concentrations in urban areas, particularly in the Des Plaines River Basin, were generally higher than in other areas of the upper Illinois River Basin. Median concentrations of the five nutrient forms at the eight fixed-monitoring stations from 1987 to 1991 are listed in table 5. Total nitrogen concentrations at the Kankakee River at Momence, Ill. (map reference number 14), were relatively low, and concentrations at the Iroquois River at Chebanse, Ill. (map reference number 28), were relatively high. Both stations drain areas of comparable size and land use with similar fertilizer application rates. Although both stations were in the Kankakee River Basin, differences in soil types necessitate different agricultural-drainage practices between the areas draining to these stations. Soils in the area draining to map reference number 14 typically are well drained, whereas soils in the area draining to map reference number 28 typically are poorly drained and, thus, extensively tile drained. Tile drainage in the Iroquois River Basin is a probable factor resulting in the higher nitrogen concentrations in the Iroquois River.

Although most of the nitrogen in the upper Illinois River Basin streams was in the form of nitrate, ammonia concentrations indicated differences between sites draining urban and rural areas. Median concentrations of nitrite plus nitrate ranged from 0.22 to $9.80 \mathrm{mg} / \mathrm{L}$ at the fixed-monitoring stations, and median concentrations of ammonia at the fixedmonitoring stations ranged from 0.01 to $7.40 \mathrm{mg} / \mathrm{L}$. Concentrations of ammonia were higher at sites with urban drainage areas and substantial upstream inputs from wastewater-treatment plants. Most high ammonia concentrations were detected in the Des Plaines and Du Page Rivers; all concentrations greater than $10 \mathrm{mg} / \mathrm{L}$ were observed in the Des Plaines and Du Page Rivers. Concentrations in the Kankakee River were the lowest in the upper Illinois River Basin.

Median organic nitrogen concentrations ranged from 0.87 to $1.70 \mathrm{mg} / \mathrm{L}$ at the fixed-monitoring stations. Organic nitrogen composed a larger portion of the total nitrogen concentration at the stations in the Fox River Basin than at the other fixed-monitoring stations. During the low-flow synoptic survey, the highest organic nitrogen concentrations (up to $14.2 \mathrm{mg} / \mathrm{L}$ ) were detected in the Des Plaines River Basin. Point-source inputs were the probable cause 


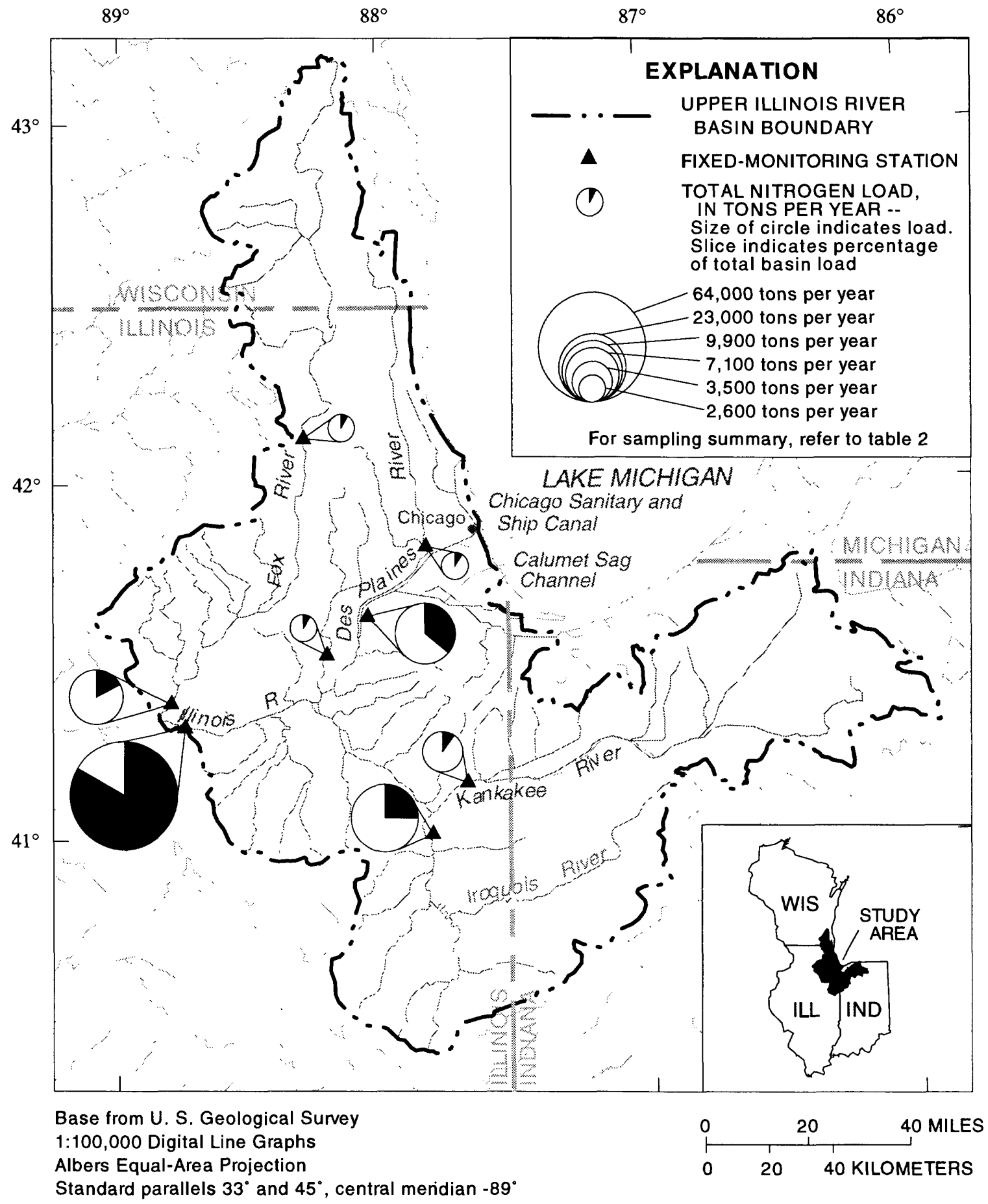

Figure 21. Loads of total nitrogen measured at the eight fixed-monitoring stations in the upper Illinois River Basin, water years $1987-91$. 
Table 5. Statistical summary of nutrient concentrations at the eight fixed-monitoring stations in the upper Illinois River Basin, water years 1987-91 (from Terrio, 1994a, p. 79)

[Number in parentheses is WATSTORE (WATer STOrage and REtrieval system) parameter code; all concentrations are in milligrams per liter]

\begin{tabular}{|c|c|c|c|c|c|c|c|}
\hline \multirow{2}{*}{$\begin{array}{c}\text { Map } \\
\text { reference } \\
\text { number } \\
\text { (see fig. 5) } \\
\end{array}$} & \multirow[b]{2}{*}{ Station name } & \multirow[b]{2}{*}{$\begin{array}{c}\text { Number of } \\
\text { observations }\end{array}$} & \multicolumn{5}{|c|}{ Percentile } \\
\hline & & & 10 & 25 & $\begin{array}{c}50 \\
\text { (median) }\end{array}$ & 75 & 90 \\
\hline \multicolumn{8}{|c|}{ Total nitrogen (00600) } \\
\hline 14 & Kankakee River at Momence, Ill. & 49 & 0.960 & 1.32 & 2.20 & 3.30 & 5.60 \\
\hline 28 & Iroquois River near Chebanse, Ill. & 40 & 2.51 & 6.42 & 9.78 & 12.70 & 15.10 \\
\hline 40 & Des Plaines River at Riverside, Ill. & 43 & 4.40 & 5.10 & 6.50 & 8.01 & 9.70 \\
\hline 55 & Chicago Sanitary and Ship Canal at Romeoville, Ill. & 43 & 4.50 & 5.50 & 7.10 & 8.70 & 9.06 \\
\hline 69 & Du Page River at Shorewood, Ill. & 48 & 6.00 & 7.30 & 8.30 & 9.50 & 10.6 \\
\hline 76 & Illinois River at Marseilles, Ill. & 59 & 4.00 & 5.00 & 6.50 & 7.80 & 9.50 \\
\hline 89 & Fox River at Algonquin, Ill. & 37 & 2.30 & 2.70 & 3.06 & 3.80 & 4.06 \\
\hline 99 & Fox River at Dayton, Ill. & 35 & 3.16 & 4.00 & 4.60 & 6.00 & 7.82 \\
\hline \multicolumn{8}{|c|}{ Total ammonia nitrogen (00610) } \\
\hline 14 & Kankakee River at Momence, Ill. & 52 & .093 & .100 & .100 & .130 & .177 \\
\hline 28 & Iroquois River near Chebanse, Ill. & 53 & .084 & .100 & .100 & .160 & .240 \\
\hline 40 & Des Plaines River at Riverside, Ill. & 44 & .105 & .208 & .395 & .538 & .710 \\
\hline 55 & Chicago Sanitary and Ship Canal at Romeoville, Ill. & 68 & .829 & 1.42 & 3.10 & 4.70 & 5.78 \\
\hline 69 & Du Page River at Shorewood, Ill. & 75 & .089 & .100 & .100 & .280 & .446 \\
\hline 76 & Illinois River at Marseilles, Ill. & 73 & .144 & .235 & .400 & .920 & 1.70 \\
\hline 89 & Fox River at Algonquin, Ill. & 71 & .060 & .100 & .100 & .160 & .440 \\
\hline 99 & Fox River at Dayton, Ill. & 46 & .020 & .040 & .085 & .200 & .320 \\
\hline \multicolumn{8}{|c|}{ Dissolved nitrite plus nitrate nitrogen (00631) } \\
\hline 14 & Kankakee River at Momence, Ill. & 85 & .540 & .740 & 1.10 & 2.35 & 4.20 \\
\hline 28 & Iroquois River near Chebanse, Ill. & 87 & 1.90 & 6.50 & 9.80 & 11.0 & 13.0 \\
\hline 40 & Des Plaines River at Riverside, Ill. & 87 & 2.30 & 3.70 & 4.60 & 5.70 & 7.22 \\
\hline 55 & Chicago Sanitary and Ship Canal at Romeoville, Ill. & 111 & 1.22 & 1.40 & 2.90 & 4.00 & 5.28 \\
\hline 69 & Du Page River at Shorewood, Ill. & 120 & 4.50 & 5.02 & 6.30 & 7.77 & 9.30 \\
\hline 76 & Illinois River at Marseilles, Ill. & 106 & 2.77 & 3.10 & 4.50 & 5.80 & 7.36 \\
\hline 89 & Fox River at Algonquin, Ill. & 113 & .100 & .100 & .220 & 1.45 & 2.30 \\
\hline 99 & Fox River at Dayton, Ill. & 86 & .100 & .490 & 2.70 & 4.12 & 5.10 \\
\hline \multicolumn{8}{|c|}{ Total organic nitrogen (00605) } \\
\hline 14 & Kankakee River at Momence, Ill. & 25 & .26 & .54 & .87 & 1.2 & 1.8 \\
\hline 28 & Iroquois River near Chebanse, Ill. & 25 & .49 & .67 & .98 & 1.4 & 2.5 \\
\hline 40 & Des Plaines River at Riverside, Ill. & 42 & .90 & 1.1 & 1.3 & 1.7 & 2.0 \\
\hline 55 & Chicago Sanitary and Ship Canal at Romeoville, Ill. & 43 & .44 & .70 & 1.1 & 1.4 & 1.8 \\
\hline 69 & Du Page River at Shorewood, Ill. & 35 & .30 & .80 & 1.1 & 1.6 & 2.9 \\
\hline 76 & Illinois River at Marseilles, Ill. & 70 & .73 & .89 & 1.0 & 1.2 & 1.6 \\
\hline 89 & Fox River at Algonquin, Ill. & 37 & .94 & 1.2 & 1.7 & 2.2 & 3.1 \\
\hline 99 & Fox River at Dayton, Ill. & 37 & .86 & 1.3 & 1.8 & 2.7 & 3.2 \\
\hline \multicolumn{8}{|c|}{ Total phosphorus (00665) } \\
\hline 14 & Kankakee River at Momence, Ill. & 91 & .040 & .040 & .060 & .100 & .170 \\
\hline 28 & Iroquois River near Chebanse, Ill. & 97 & .050 & .066 & .100 & .170 & .262 \\
\hline 40 & Des Plaines River at Riverside, Ill. & 82 & .423 & .617 & .840 & 1.18 & 1.48 \\
\hline 55 & Chicago Sanitary and Ship Canal at Romeoville, Ill. & 107 & .44 & .530 & .640 & .850 & 1.10 \\
\hline 69 & Du Page River at Shorewood, Ill. & 114 & .615 & .707 & .820 & 1.20 & 1.70 \\
\hline 76 & Illinois River at Marseilles, Ill. & 111 & .272 & .330 & .410 & .480 & .570 \\
\hline 89 & Fox River at Algonquin, Ill. & 110 & .090 & .120 & .160 & .250 & .319 \\
\hline 99 & Fox River at Dayton, Ill. & 83 & .120 & .170 & .230 & .310 & .356 \\
\hline
\end{tabular}


for elevated concentrations of organic nitrogen in the Des Plaines River Basin during low-flow periods.

The spatial distribution of phosphorus concentrations was similar to the distribution for total nitrogen. Median concentrations of total phosphorus ranged from 0.06 to $0.84 \mathrm{mg} / \mathrm{L}$ at the fixed-monitoring stations. During the low-flow synoptic survey, phosphorus concentrations greater than $1.0 \mathrm{mg} / \mathrm{L}$ were observed at 13 stations, which were in the Chicago metropolitan area. The highest phosphorus concentration detected was $4.0 \mathrm{mg} / \mathrm{L}$ in Salt Creek at Wooddale, Ill. (map reference number 37 ). The spatial distribution of total phosphorus concentrations was similar to that for total nitrogen, except concentrations were not high in the Iroquois River. Phosphorus tends to adsorb to fine-sized sediment particles, which generally would not be discharged from tile drains. This is probably why phosphorus concentrations in the Iroquois River Basin were not higher than in other parts of the study area, whereas nitrogen concentrations in the Iroquois River Basin were higher than in other parts of the study area.

Total nitrogen concentrations correlated with streamflow at most of the fixed-monitoring stations. Positive correlations of streamflow and total nitrogen concentrations were found at most agricultural stations, whereas negative correlations were found at most urban stations (table 6). A probable explanation for these correlations is that runoff was a major source of nitrogen to streams in agricultural areas, whereas point sources, which are diluted by runoff, were the major nitrogen sources in urban areas.

Phosphorus concentrations and streamflow were negatively correlated at four of the fixed-monitoring stations and positively correlated at Iroquois River near Chebanse, Ill. (map reference number 28). A probable explanation of this positive correlation is that erosion, suspension, and transport of sediment-related phosphorus during periods of increased streamflow resulted in higher observed phosphorus concentrations during high flow. A probable explanation of the negative correlations at the other stations is that the high flows diluted the phosphorus from point sources.

Upward trends in total nitrogen concentrations from 1978 to 1990 were observed at three of the fixedmonitoring stations: Iroquois River near Chebanse, Ill. (map reference number 28), Des Plaines River at Riverside, Ill. (map reference number 40), and Du Page River at Shorewood, Ill. (map reference number 69); the upward trends ranged from 2.9 to 9.0 percent of median concentration per year. Downward trends in total phosphorus concentrations were observed at three fixed-monitoring stations: Des Plaines River at Riverside, Ill. (map reference number 40), Illinois River at Marseilles, Ill. (map reference number 76), and Fox River at Dayton, Ill. (map reference number 99 ). The trends ranged from -3.3 to 7.1 percent of median concentration per year. The uptrends in

Table 6. Correlation coefficients for nutrient concentrations and discharge at the eight fixed-monitoring stations in the upper Illinois River Basin, water years 1987-91 (from Terrio, 1994a)

[Number in parentheses is WATSTORE (WATer STOrage and REtrieval system) parameter code; $n$, number of observations; $\rho^{2}$, Spearman's rho rank correlation coefficient; <, less than]

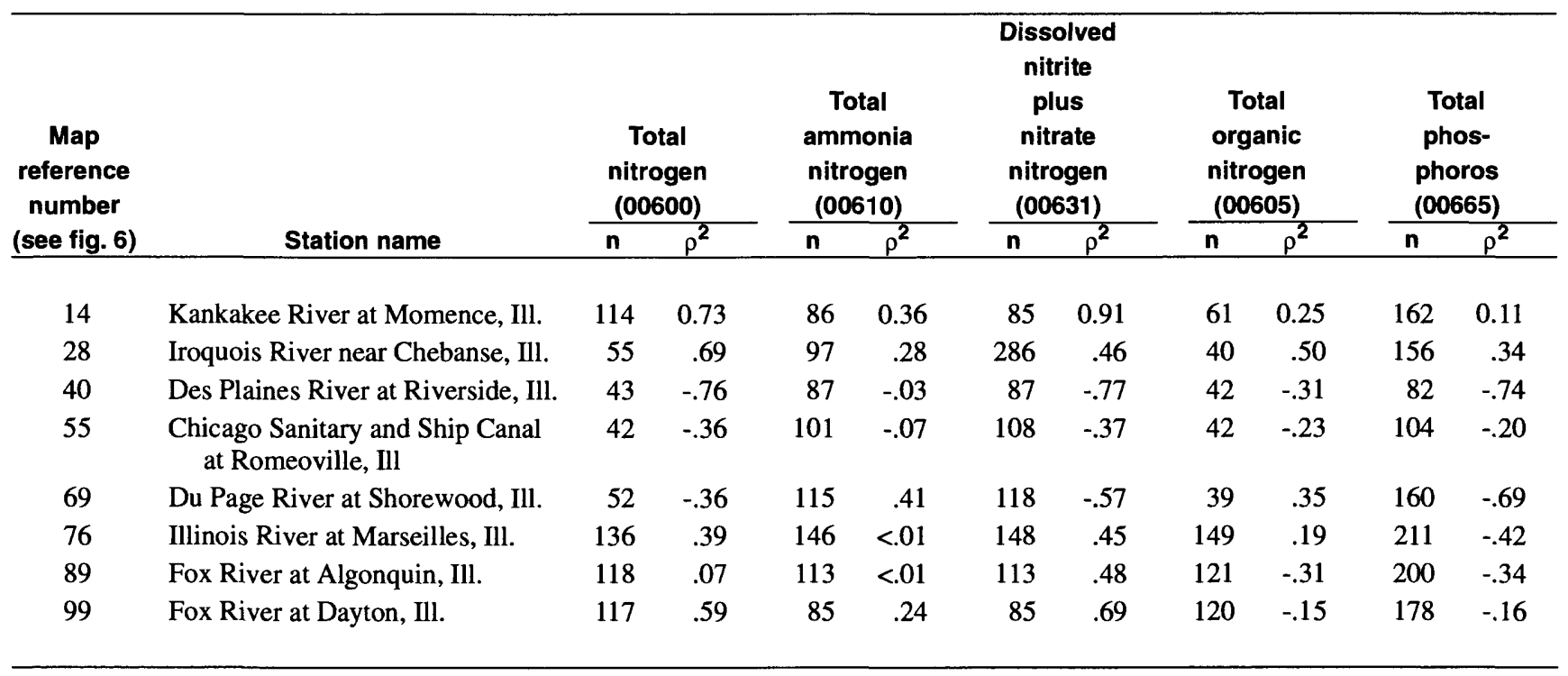


nitrogen concentrations might be from increased application of fertilizers and urbanization. The downtrends in phosphorus (map reference numbers 76 and 99) might be from decreased use of phosphate cleansers and improved wastewater treatment in the basin.

Nutrient concentrations at several of the fixedmonitoring stations typically were high in the winter and low in the summer. Because these variations were observed at stations draining areas with different land uses, seasonal changes in physical, chemical, and biological processes were the likely factors causing seasonal changes in nutrient concentrations. Nutrient inputs to the streams also can vary with climatic season and hydrologic conditions.

Median dissolved oxygen concentrations at the fixed-monitoring stations ranged from $3.4 \mathrm{mg} / \mathrm{L}$ at the Chicago Sanitary and Ship Canal at Romeoville, Ill. (map reference number 55), to $12.2 \mathrm{mg} / \mathrm{L}$ at the Fox River at Dayton, Ill. (map reference number 99). Median concentrations at the other fixed-monitoring stations were from 8.7 to $9.7 \mathrm{mg} / \mathrm{L}$ (table 7).

Dissolved oxygen concentrations at map reference number 55 were probably low in part because flow at this station during low-flow conditions is about 65 percent wastewater effluent. Velocities at this station during low-flow conditions are low (less than $0.5 \mathrm{ft} / \mathrm{s}$ ), and depths are large (about $27 \mathrm{ft}$ ), resulting in little reaeration. Dissolved oxygen concentrations at map reference number 99 probably were high, in part, because of algae and plant photosynthesis in the pooled areas behind the dams upstream from this station.
Dissolved oxygen concentrations measured during a synoptic sampling for dissolved oxygen, nutrients, and fecal-indicator bacteria exceeded State water-quality standards at 76 percent of the sites sampled. Dissolved oxygen concentrations were measured in the early morning hours (generally $0500-0800$ ) during the 1988 low-flow synoptic survey. This resulted in the measurement of minimum diel-varying concentrations. Dissolved oxygen concentrations were less than $5 \mathrm{mg} / \mathrm{L}$ at 20 of the 60 sites sampled (fig. 22). In the Kankakee River Basin, dissolved oxygen concentrations less than $5 \mathrm{mg} / \mathrm{L}$ were measured at 10 of the 17 stations, including map reference number 29 with the lowest measured concentration $(1.85 \mathrm{mg} / \mathrm{L})$. In contrast, dissolved oxygen concentrations at all stations measured in the Fox River were greater than $5 \mathrm{mg} / \mathrm{L}$.

Diel variations in dissolved oxygen concentrations were measured at three of the fixed-monitoring stations (fig. 23). The diel variations are controlled primarily by plant photosynthesis and respiration. Chlorophyll- $a$ concentrations for these stations (fig. 24) indicate that photosynthesis probably caused the large diel variations observed at map reference number 89 .

Upward trends in dissolved oxygen concentrations from 1978 to 1990 were observed at the two most downstream stations in the upper Illinois River Basin (Illinois River at Marseilles, Ill. (map reference number 76), and Fox River at Dayton, Ill. (map

Table 7. Statistical summary of dissolved oxygen concentrations at the eight fixed-monitoring stations in the upper Illinois River Basin, water years 1987-91 (from Terrio, 1994a)

[All concentrations are in milligrams per liter]

\begin{tabular}{|c|c|c|c|c|c|c|c|}
\hline \multirow{2}{*}{$\begin{array}{c}\text { Map } \\
\text { reference } \\
\text { number } \\
\text { (see fig. 6) } \\
\end{array}$} & \multirow[b]{2}{*}{ Station name } & \multirow[b]{2}{*}{$\begin{array}{c}\text { Number of } \\
\text { observations }\end{array}$} & \multicolumn{5}{|c|}{ Percentile } \\
\hline & & & 10 & 25 & $\begin{array}{c}50 \\
\text { (median) }\end{array}$ & 75 & 90 \\
\hline 14 & Kankakee River at Momence, Ill. & 475 & 6.9 & 8.2 & 9.6 & 11.2 & 12.1 \\
\hline 28 & Iroquois River near Chebanse, Ill. & 816 & 3.4 & 6.2 & 8.8 & 11.4 & 12.3 \\
\hline 55 & $\begin{array}{l}\text { Chicago Sanitary and Ship Canal } \\
\text { at Romeoville, Ill. }\end{array}$ & 615 & 2.0 & 2.9 & 3.4 & 4.9 & 7.0 \\
\hline 69 & Du Page River at Shorewood, Ill. & 491 & 7.0 & 8.2 & 9.7 & 12.3 & 15.0 \\
\hline 76 & Illinois River at Marseilles, Ill. & 509 & 6.7 & 7.6 & 9.7 & 11.8 & 13.2 \\
\hline 89 & Fox River at Algonquin, Ill. & 618 & 5.0 & 6.3 & 8.7 & 11.3 & 14.8 \\
\hline
\end{tabular}




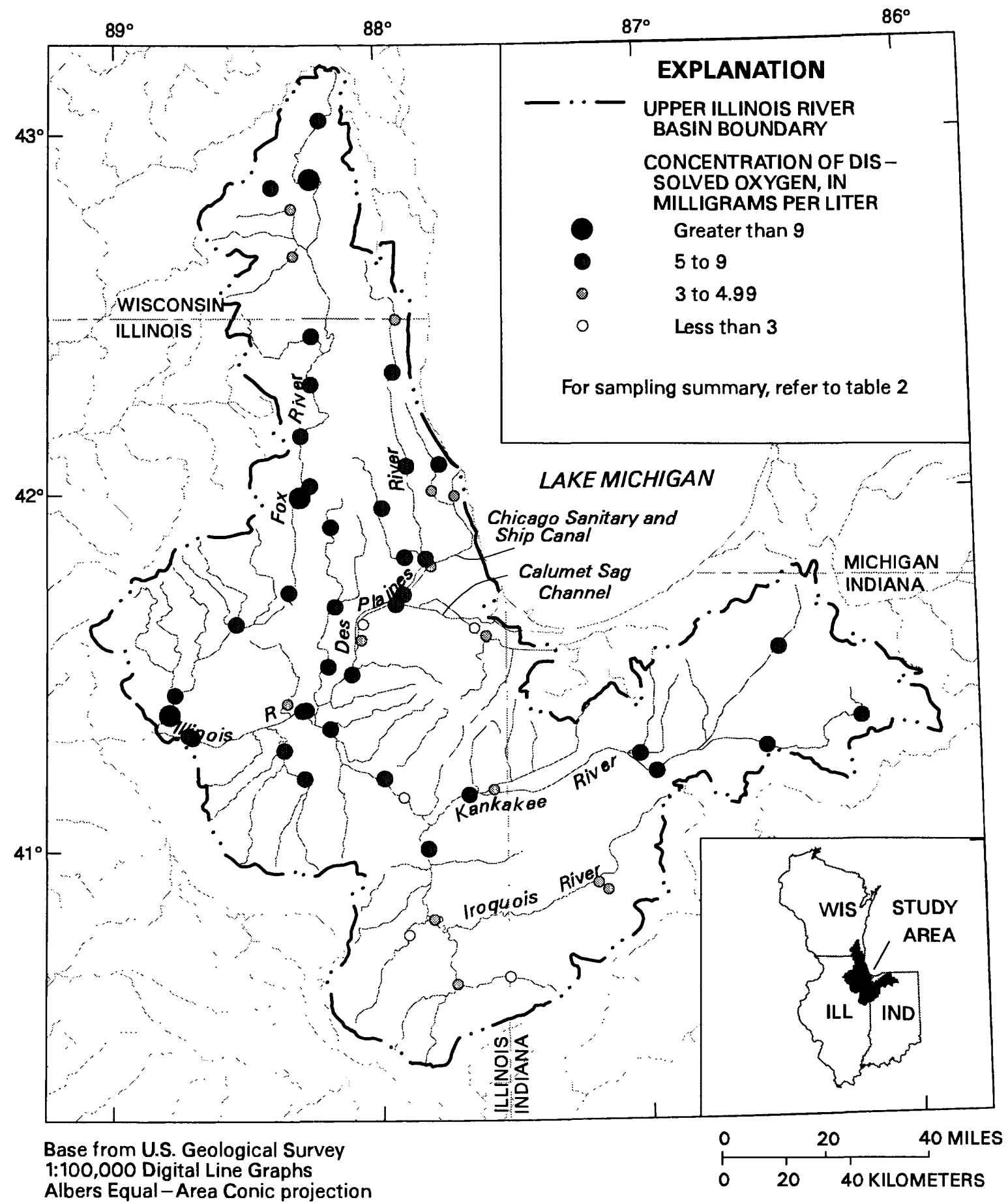

Standard parallels $33^{\circ}$ and $45^{\circ}$, central meridian $-89^{\circ}$

Figure 22. Spatial distribution of dissolved oxygen concentrations in water measured duning the low-flow synoptic survey in the upper Illinois River Basin, July 25-August 13, 1988.

reference number 99)). The slope of the upward trend was $0.2 \mathrm{mg} / \mathrm{L}$ ( 2 percent of the median) per year.

Fecal coliform and Escherichia Coli (E. Coli) were used to indicate bacterial pollution in the upper Illinois River Basin. A statistical analysis of paired $E$.
Coli and fecal coliform data showed that there are no statistically significant differences in the density data from the two tests (Terrio, 1994a, p. 76). Density of $E$. Coli at the eight fixed-monitoring stations ranged from 1 to $45,000 \mathrm{col} / 100 \mathrm{~mL}$ (table 8). Median 


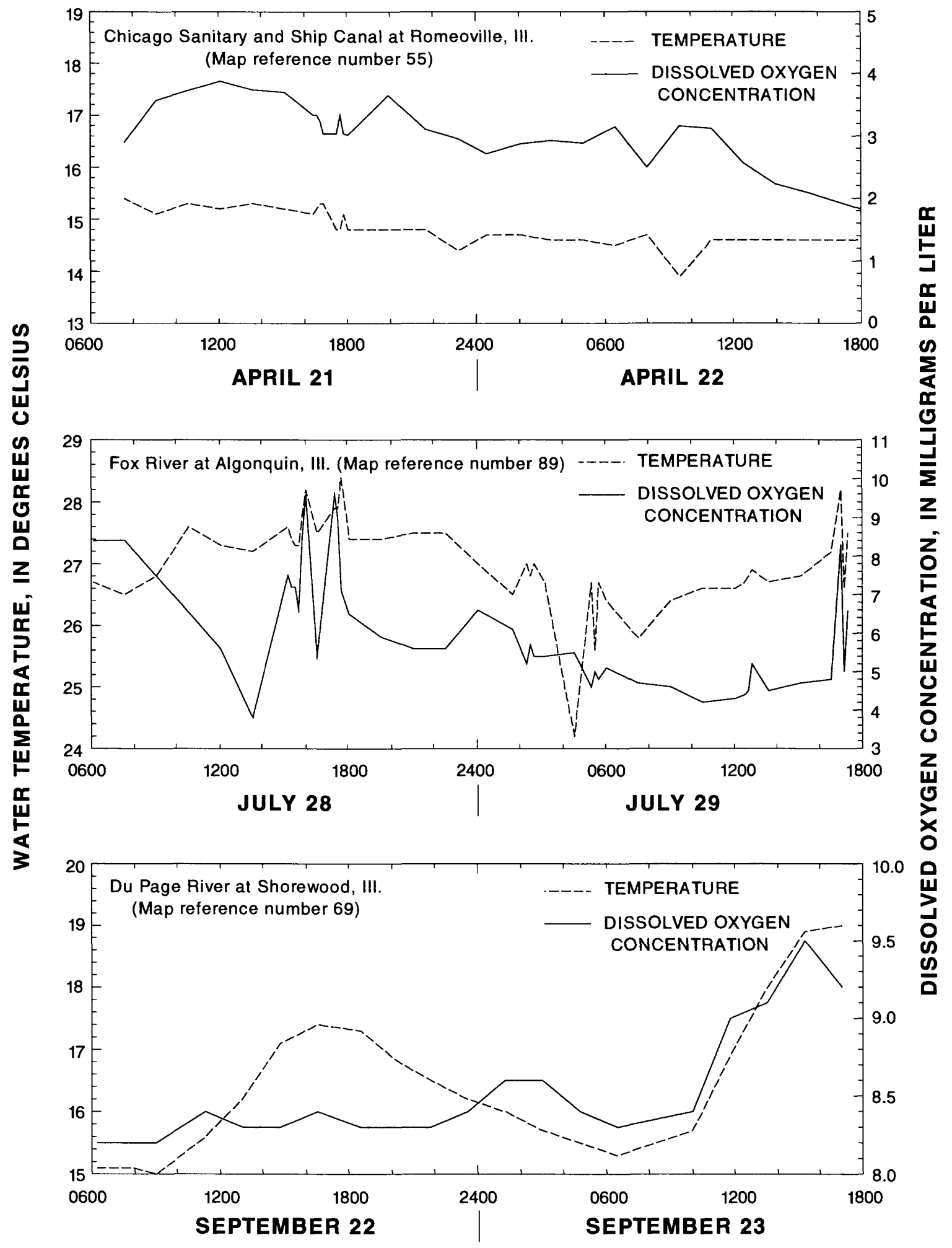

Figure 23. Diel-variations in temperature and dissolved oxygen concentrations at three fixed-monitoring stations during the low-flow synoptic survey in the upper Illinois River Basin, during 36-hour periods. 


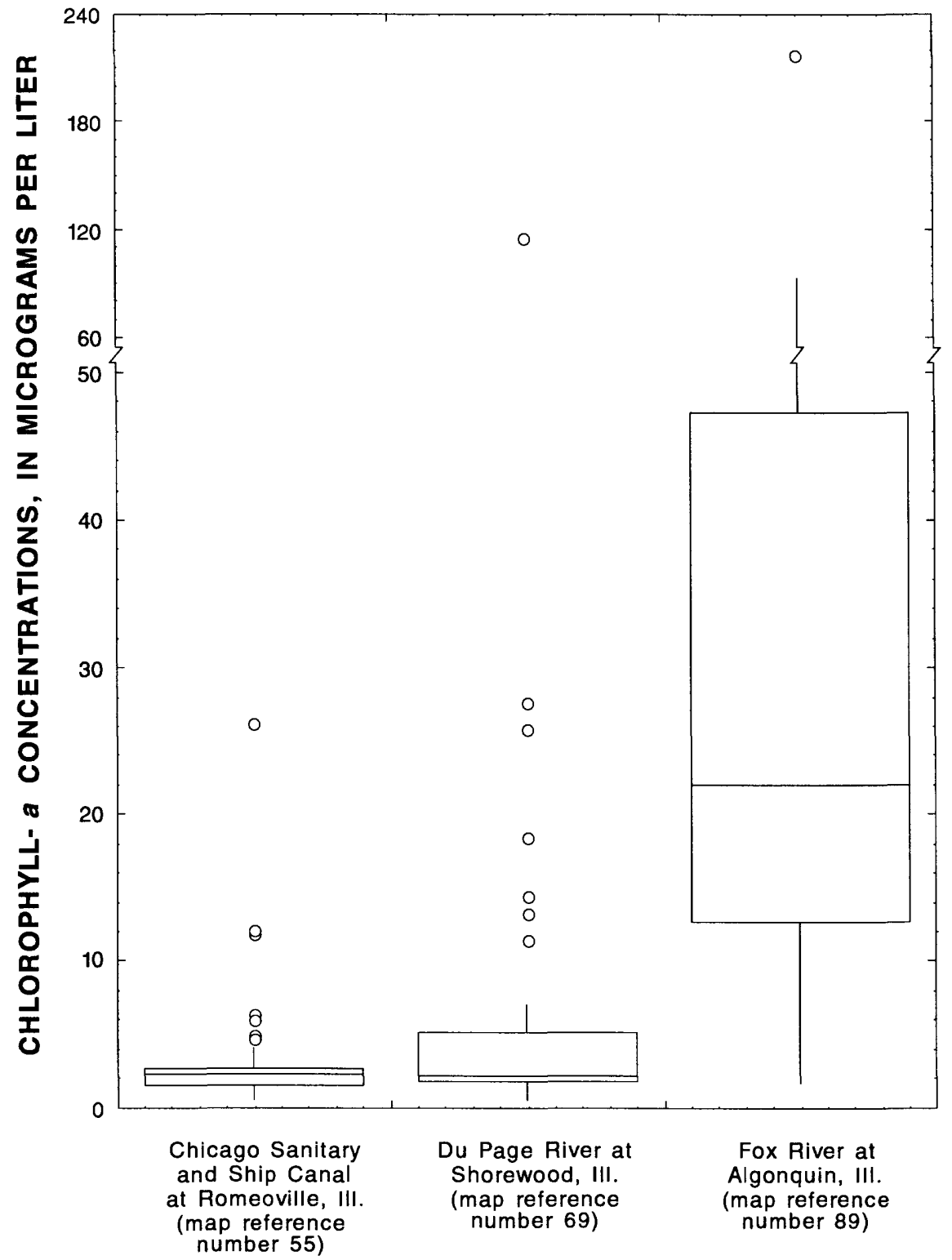

\section{FIXED-MONITORING STATIONS \\ EXPLANATION}

- D Data value(s) exceeding upper quartile

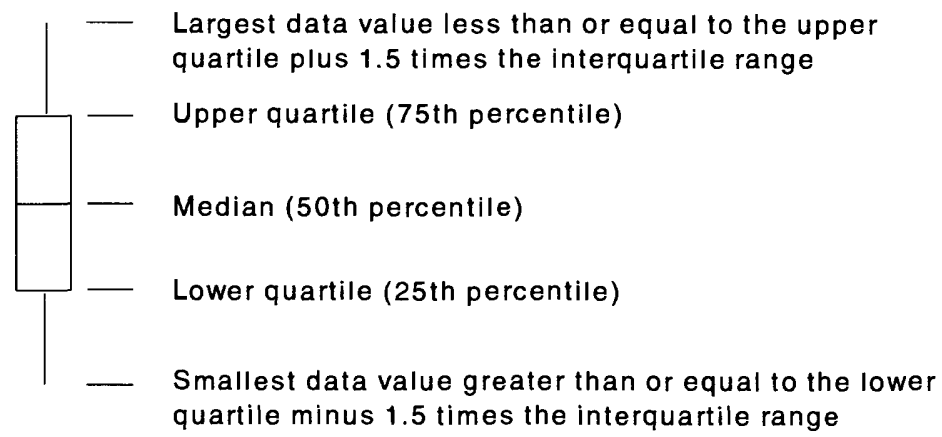

Figure 24. Chlorophyll-a concentrations in water measured at three fixedmonitoring stations in the upper Illinois River Basin, water years 1987-91. 
Table 8. Statistical summary of fecal-indicator bacteria densities at the eight fixed-monitoring stations in the upper llinois River Basin, water years 1987-90 (from Terrio, 1994a, p. 79)

[All densities are in colonies per 100 milliliters; --, no data]

\begin{tabular}{|c|c|c|c|c|c|c|c|c|c|}
\hline \multirow{2}{*}{$\begin{array}{c}\text { Map } \\
\text { reference } \\
\text { number } \\
\text { (see fig. 6) } \\
\end{array}$} & \multirow[b]{2}{*}{ Station name } & \multirow[b]{2}{*}{$\begin{array}{l}\text { Number of } \\
\text { observations }\end{array}$} & \multirow[b]{2}{*}{ Minimum } & \multirow[b]{2}{*}{ Maximum } & \multicolumn{5}{|c|}{ Percentile } \\
\hline & & & & & 10 & 25 & $\begin{array}{c}50 \\
\text { (median) }\end{array}$ & 75 & 90 \\
\hline \multicolumn{10}{|c|}{ Fecal coliform (April 1987-August 1990) } \\
\hline 14 & Kankakee River at Momence, Ill. & 68 & 10 & 10,100 & 40 & 60 & 150 & 260 & 637 \\
\hline 28 & Iroquois River near Chebanse, Ill. & 66 & 4 & 9,500 & 10 & 22 & 93 & 282 & 1,760 \\
\hline 40 & Des Plaines River at Riverside, Ill. & 58 & 220 & 45,000 & 720 & 1,280 & 3,050 & 12,000 & 24,800 \\
\hline 55 & $\begin{array}{l}\text { Chicago Sanitary and Ship Canal } \\
\text { at Romeoville, Ill. }\end{array}$ & 51 & 60 & 45,000 & 284 & 430 & 1,000 & 2,250 & 12,100 \\
\hline 69 & Du Page River at Shorewood, Ill. & 65 & 3 & 14,000 & 19 & 75 & 250 & 860 & 3,880 \\
\hline 76 & Illinois River at Marseilles, Ill. & 85 & 1 & 3,100 & 16 & 28 & 60 & 115 & 318 \\
\hline 89 & Fox River at Algonquin, Ill. & 54 & 5 & 610 & 9 & 11 & 40 & 76 & 205 \\
\hline 99 & Fox River at Dayton, Ill. & 52 & 9 & 12,182 & 19 & 31 & 77 & 175 & 664 \\
\hline \multicolumn{10}{|c|}{ Escherichia Coli (July 1988-August 1990) } \\
\hline 14 & Kankakee River at Momence, Ill. & 0 & -- & -- & -- & -- & -- & -- &.- \\
\hline 28 & Iroquois River near Chebanse, Ill. & 26 & 8 & 8,000 & 11 & 45 & 91 & 422 & 1,660 \\
\hline 40 & Des Plaines River at Riverside, III. & 24 & 600 & 45,000 & 835 & 1,180 & 2,800 & 7,630 & 35,500 \\
\hline 55 & $\begin{array}{l}\text { Chicago Sanitary and Ship Canal } \\
\text { at Romeoville, Ill. }\end{array}$ & 23 & 200 & 5,600 & 358 & 531 & 1,060 & 1,670 & 4,300 \\
\hline 69 & Du Page River at Shorewood, Ill. & 24 & 3 & 15,000 & 11 & 36 & 181 & 1,480 & 13,300 \\
\hline 76 & Illinois River at Marseilles, Ill. & 22 & 16 & 2,916 & 22 & 25 & 97 & 250 & 1,930 \\
\hline 89 & Fox River at Algonquin, Ill. & 23 & 6 & 833 & 8 & 21 & 37 & 80 & 198 \\
\hline 99 & Fox River at Dayton, Ill. & 20 & 10 & 600 & 15 & 30 & 47 & 162 & 373 \\
\hline
\end{tabular}

densities at the Des Plaines River at Riverside, Ill. (map reference number 40), and the Chicago Sanitary and Ship Canal at Romeoville, Ill. (map reference number 55), were 100 times higher than the median densities from the other fixed-monitoring stations.

Observations from the 1988 synoptic survey indicated that densities were higher than $126 \mathrm{col} / 100 \mathrm{~mL}$ at 44 sites and densities were higher than $576 \mathrm{col} / 100 \mathrm{~mL}$ at 30 stations. Densities were highest in the Des Plaines River Basin (fig. 25).

Bacteria densities higher than water-quality criteria and standards were observed at all fixedmonitoring stations, but densities higher than waterquality criteria and standards were observed more often at stations in the Des Plaines River Basin. Densities for all samples analyzed for $E$. Coli from the Des Plaines River at Riverside, Ill. (map reference number 40 ), were higher than the single-sample criteria for infrequently used full-body contact recreation. Densities for approximately 73 percent of the samples collected from the Chicago Sanitary and Ship Canal at Romeoville, Ill. (map reference number 55), exceeded this criteria. Similar percentages were observed for fecal-coliform densities higher than Illinois' general-use water-quality standard of $200 \mathrm{col} / 100 \mathrm{~mL}$ for the monthly geometric mean of five or more samples from a specific site (table 9).

$E$. Coli densities were determined in samples collected during the low-flow synoptic survey in 1988 . During these conditions, the effect of point-source inputs was enhanced because of limited dilution from streamflow. E. Coli densities higher than Federal criteria for moderately and infrequently used full-body contact recreation were measured at 47 percent of the sites; this included sites in every major subbasin in the study area (fig. 25). The highest densities, up to $54,000 \mathrm{col} / 100 \mathrm{~mL}$, were measured at sites on streams and canals in the Chicago metropolitan area designated as secondary-contact waters. $E$. Coli densities that were among the lowest in the basin were detected at the 


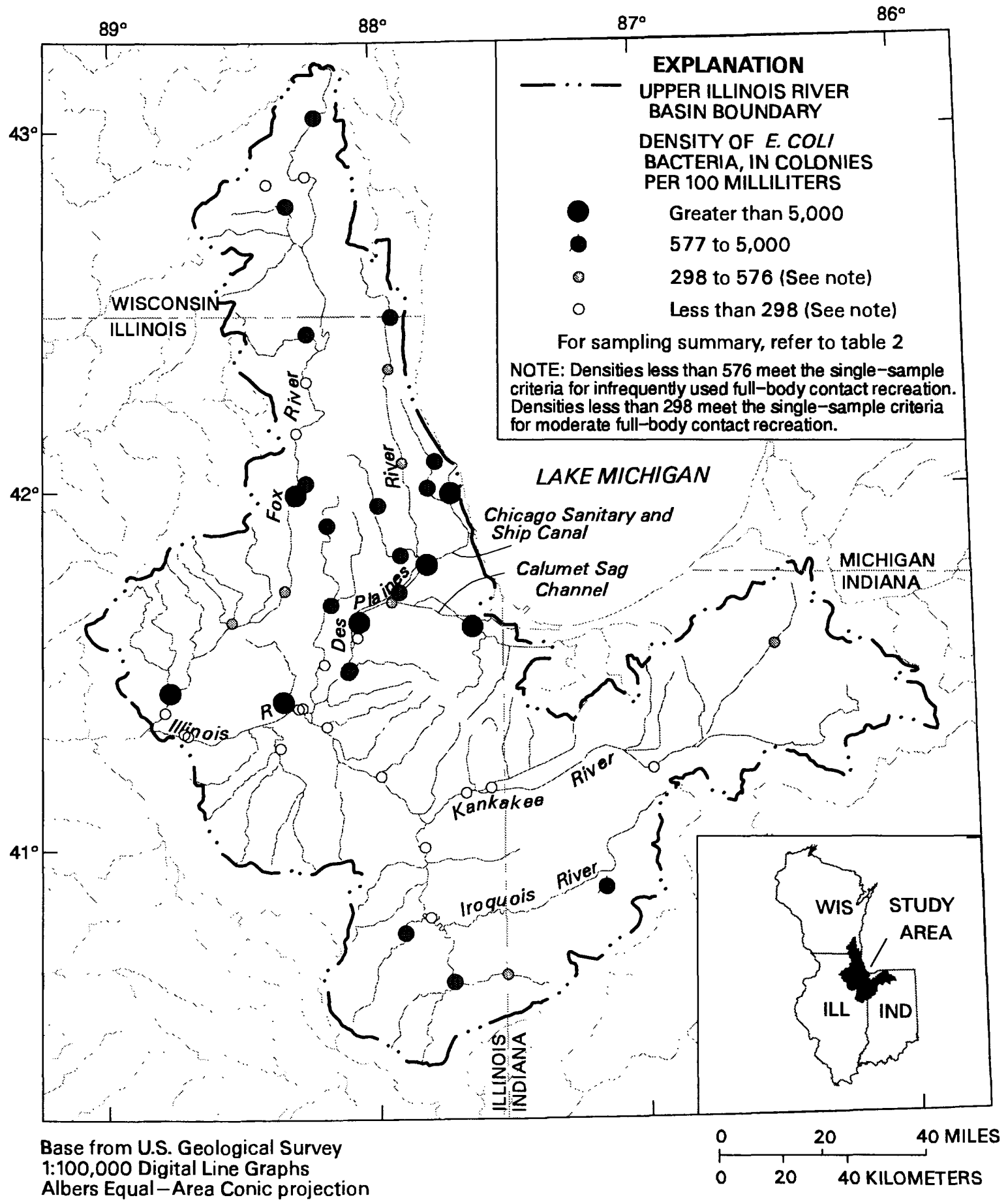

Standard parallels $33^{\circ}$ and $45^{\circ}$, central meridian $-89^{\circ}$

Figure 25. Spatial distribution of Escherichia Coli bacteria densities in water measured during the low-flow synoptic survey in the upper Illinois River Basin, July 25-August 13, 1988. 
Table 9. Relations of Federal water-quality criteria and State water-quality standards to bacteria densities at the eight fixed-monitoring stations in the upper Illinois River Basin, April 1987-August 1990 (from Terrio, 1994a, p. 79)

[<, less than]

\begin{tabular}{|c|c|c|c|c|c|c|c|}
\hline \multirow{2}{*}{$\begin{array}{l}\text { Map } \\
\text { reference } \\
\text { number } \\
\text { (see fig. 6) }\end{array}$} & \multirow[b]{2}{*}{ Station name } & \multicolumn{6}{|c|}{$\begin{array}{c}\text { Number of samples with densities greater than indicated value } \\
\text { U.S. Environmental Protection Agency criteria for } \\
\text { Escherichia Coli (colonies per } 100 \text { milliliters) }\end{array}$} \\
\hline & & $\begin{array}{l}\text { Number of } \\
\text { samples }\end{array}$ & $1_{126}$ & 2235 & ${ }^{3} 298$ & ${ }^{4} 406$ & $5_{576}$ \\
\hline 14 & Kankakee River at Momence, Ill. & 61 & 15 & 5 & 3 & 2 & 2 \\
\hline 28 & Iroquois River near Chebanse, Ill. & 134 & 22 & 9 & 7 & 5 & 4 \\
\hline 40 & Des Plaines River at Riverside, Ill. & 49 & 22 & 22 & 22 & 22 & 22 \\
\hline 55 & $\begin{array}{l}\text { Chicago Sanitary and Ship Canal } \\
\text { at Romeoville, Ill. }\end{array}$ & 50 & 21 & 21 & 20 & 20 & 16 \\
\hline 69 & Du Page River at Shorewood, Ill. & 57 & 22 & 11 & 9 & 7 & 7 \\
\hline 76 & Illinois River at Marseilles, Ill. & 60 & 18 & 6 & 4 & 3 & 2 \\
\hline 89 & Fox River at Algonquin, Ill. & 52 & 19 & 1 & 1 & 1 & 1 \\
\hline 99 & Fox River at Dayton, Ill. & 50 & 16 & 3 & 3 & 1 & 1 \\
\hline
\end{tabular}

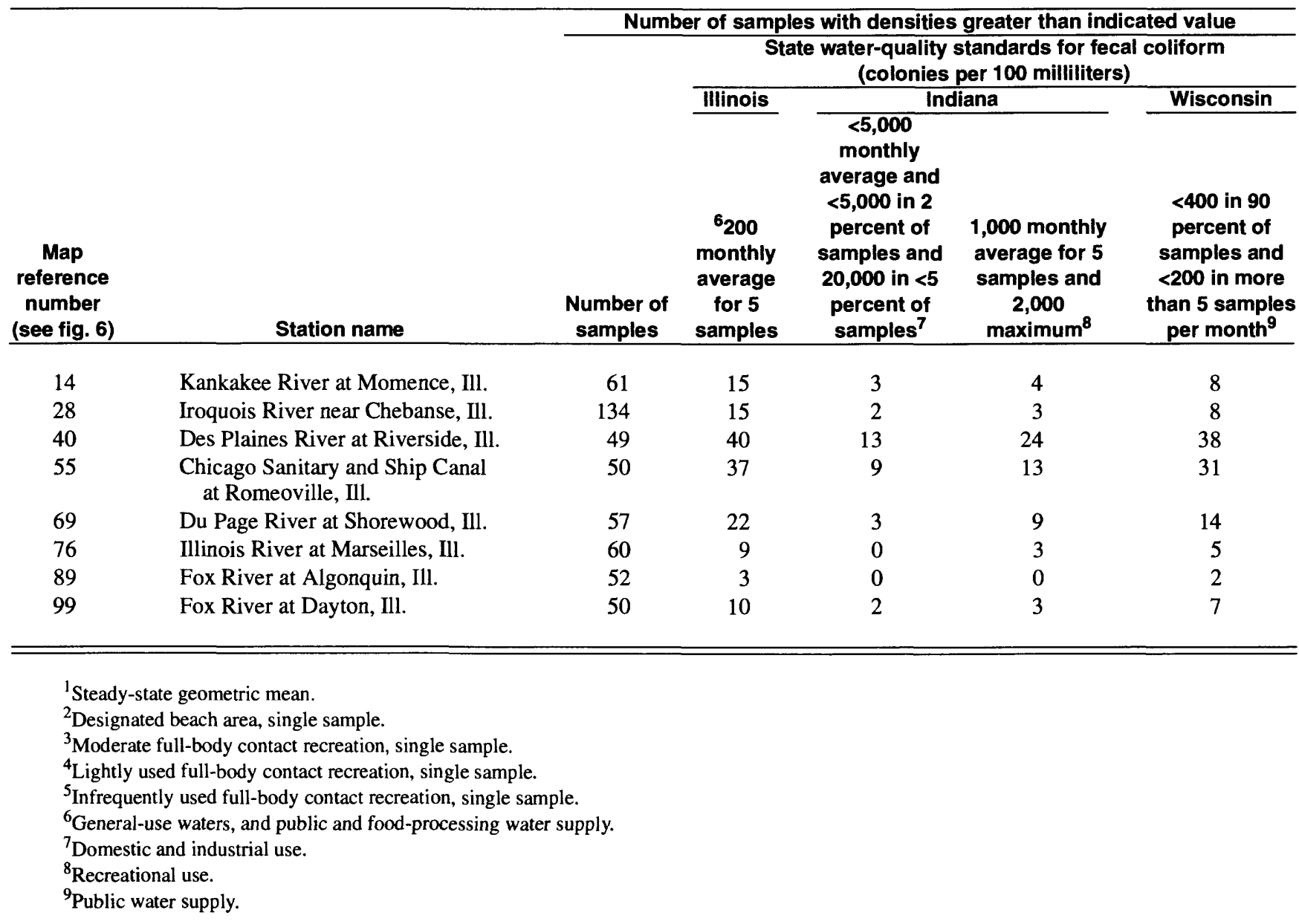

two sites most downstream in the study area-Fox River at Dayton, Ill. (map reference number 99), and Illinois River at Marseilles, Ill. (map reference number 76).
Significant downward trends in fecal-coliform densities from 1978 to 1990 were observed at three fixed-monitoring stations draining largely agricultural basins (Terrio, 1994a): Iroquois River near Chebanse, 
(map reference number 28), Fox River at Algonquin, Ill. (map reference number 89 ), and Fox River at Dayton, Ill. (map reference number 99). The magnitude of the downward trends ranged from -7.0 to -14.2 percent of the median density per year. No significant trends were observed at stations in urban areas for 1978-90.

\section{RESULTS OF STUDIES AND IMPLICATIONS FOR THE NATIONAL WATER-QUALITY ASSESSMENT PROGRAM}

Studies were done in the upper Illinois River Basin to test the viability of using components of the NAWQA program to evaluate the effect of changes to wastewater-treatment practices on stream-water quality and using fish-community composition and structure as a measure of water quality. Study results are summarized in this section; details of these studies are given in Ruhl (1995), Terrio (1994b), and Zogorski and others (1990).

\section{Availability and Suitability of Information on Municipal Wastewater-Treatment Practices for Large-Scale Water-Quality Assessments}

A study was done to describe the availability and suitability of information on municipal wastewater treatment and effluent characteristics for use in the NAWQA program. The study addressed the question "What have been the effects of changes in municipal wastewater treatment on stream quality and ecosystem health?" (Zogorski and others, 1990).

Forty-eight of 118 wastewater-treatment plants in the upper Illinois River Basin were examined to determine the extent of available data on treatment and effluent characteristics. All 48 of the municipal wastewater-treatment plants maintained continuous records of effluent flow rates. No daily flow rates were entered into State or Federal data bases, but about 50 percent of the major wastewater-treatment plants entered their daily flow-rate data into a local computer data base. Except for wastewater-treatment plants operated by the MWRDGC, which monitors 43 constituents daily, only 8 water-quality characteristics-fecal-coliform bacteria, total chlorine residual, total phosphorus, ammonia nitrogen, suspended solids, carbonaceous biochemical oxygen demand, biochemical oxygen demand, and $\mathrm{pH}$ - were commonly measured in effluent samples.

Although much information on wastewatertreatment and effluent characteristics is available, this information is of limited use for accomplishing the objectives of a national assessment. This information would be improved by (1) increasing the number of water-quality constituents routinely monitored in municipal effluent samples, (2) increasing the frequency of effluent monitoring at many locations and utilizing flow-weighted 24-hour composite samples for selected constituents, and (3) developing and utilizing a quality-assurance plan for effluent flow-rate determinations.

\section{Evaluation of the Effects of Changes in Wastewater-Treatment Practices on Stream-Water Quality}

Relations between changes in wastewatertreatment practices and stream-water quality were evaluated as part of the assessment of the upper Illinois River Basin (Terrio, 1994b). Relation of changes in the water chemistry in the Calumet Sag Channel to changes in practices at the MWRDGC's Calumet wastewater-treatment plant (design average discharge of $354 \mathrm{Mgal} / \mathrm{d}$ ) and the implementation of Chicago's Tunnel and Reservoir Plan (TARP) system in the Chicago metropolitan area to capture overflow from combined sewers were examined. Relation of changes in the water chemistry in the Des Plaines River Basin to changes in practices at four large wastewatertreatment plants (design average discharge from 55 to 1,440 Mgal/d) also were examined.

Two major changes in wastewater-treatment practices between 1983 and 1986-88 were considered. In 1983, the Calumet wastewater-treatment plant, with approval from the IEPA, ceased effluent disinfection. In 1986-87, runoff from combined sewers in the service area of the wastewater-treatment plant were discharged to the TARP system. During 1987-88, additional blowers were installed, and diffusers were replaced, which increased the aeration in the secondary treatment at this plant. The effects of the TARP system and improved secondary-treatment aeration were considered to have occurred concurrently for this evaluation.

Fecal-coliform bacteria densities increased at sampling sites downstream from the Calumet 
wastewater-treatment plant after disinfection of the effluent was discontinued. However, increases were limited to the vicinity of the wastewater-treatment plant. No change in bacteria densities was observed at sampling sites farther than $7 \mathrm{mi}$ downstream, although effluent composed about 45-75 percent of the streamflow.

Significant changes in concentrations of suspended solids and other constituents were observed in water samples from the effluent of the wastewatertreatment plant and from the Calumet Sag Channel after the TARP system began to collect overflow from combined sewers, and aeration was improved at the wastewater-treatment plant (table 10). Biochemical oxygen demand (BOD) decreased in the effluent and at all downstream sites. The BOD of effluent decreased from a median of $19 \mathrm{mg} / \mathrm{L}$ to a median of $15 \mathrm{mg} / \mathrm{L}$, and median BOD at the downstream sites decreased by 3-4 mg/L. Median ammonia concentrations of effluent decreased from 12.4 to $3.6 \mathrm{mg} / \mathrm{L}$. Downstream ammonia concentrations decreased about $3.5-4.5 \mathrm{mg} / \mathrm{L}$. For BOD and ammonia, the probable causes for the decrease in effluent and downstream concentrations were the improvements in aeration made at the Calumet wastewater-treatment plant in 1987-88.

Other appreciable changes in concentrations of suspended solids and other constituents that may have resulted from the implementation of Phase I of the TARP system and improvements to aeration at the Calumet wastewater-treatment plant are shown in table 10 . The decreases primarily were in samples with concentrations at the extreme high end of the distribution. The decreases are to be expected as the effects of the TARP system are limited to runoff periods, which would correspond to the extreme samples. The distribution of concentrations after the TARP system was implemented were significantly different from those before the TARP system. These differences are indicated in the percentile plots of the distribution of concentrations before and after the TARP system (fig. 26).

The effects of the changes in wastewatertreatment practices on the biota of the Little Calumet River and the Calumet Sag Channel were examined using fish-sampling data from electrofishing surveys performed in 1974-77 and 1985-90 by the MWRDGC for six sites in the Calumet River system. Three sites were located upstream from the Calumet wastewatertreatment plant, and three sites were located downstream from the Calumet wastewater-treatment plant. Changes in fish-community structure and population, as summarized by the Index of Biotic Integrity (IBl) (Karr and others, 1986), did not indicate change following the changes in the wastewater-treatment practices. The low, high, and average IBI scores for the six fish-sampling sites for samples collected annually from 1974 to 1977 and from 2 to 3 times a year from 1985 to 1990 are shown in figure 27. All IBI scores for the sites were indicative of a poor to very poor capability of the Calumet River system to support fish communities. Although changes in IBI scores are shown in figure 27 , they do not necessarily reflect major changes in the biota of the streams. The habitat in the Calumet River system is degraded, and although habitat is not directly included in determining IBI scores, a degraded habitat can affect fish-species ecosystem in such a way as to lower IBI scores.

Results indicate that current monitoring programs in Illinois, although sufficient for their intended purposes, could be enhanced for large-scale retrospective water-quality assessments. The lack of discharge data from the stream-monitoring program prevented constituent load and mass transport analyses that would have allowed for more quantitative analyses. These analyses could have provided important additional information regarding changes in stream-water quality resulting from changes in effluent quality.

Water-quality samples collected during and following storms could have been utilized to quantify the effects of nonpoint sources-such as those discharging to the TARP system-on effluent and stream-water quality. A more comprehensive analysis of the effects of changes to wastewater-collection and -treatment practices could be made with a few enhancements to the monitoring programs.

\section{Fish-Community Composition and Structure as a Measure of Water-Quality Conditions}

Many ecologists have used multivariate analysis to study patterns between fish-community structure and water-quality conditions (Gauch, 1982; Ter Braak, 1986). As part of the upper Illinois River Basin NAWQA study (Ruhl, 1995), a widely used multivariate ordination technique, detrended correspondence analysis (DCA), was evaluated for indirect gradient analysis of relations between community structure and water-quality conditions. Of particular interest was how this technique might be applied to the analysis of 


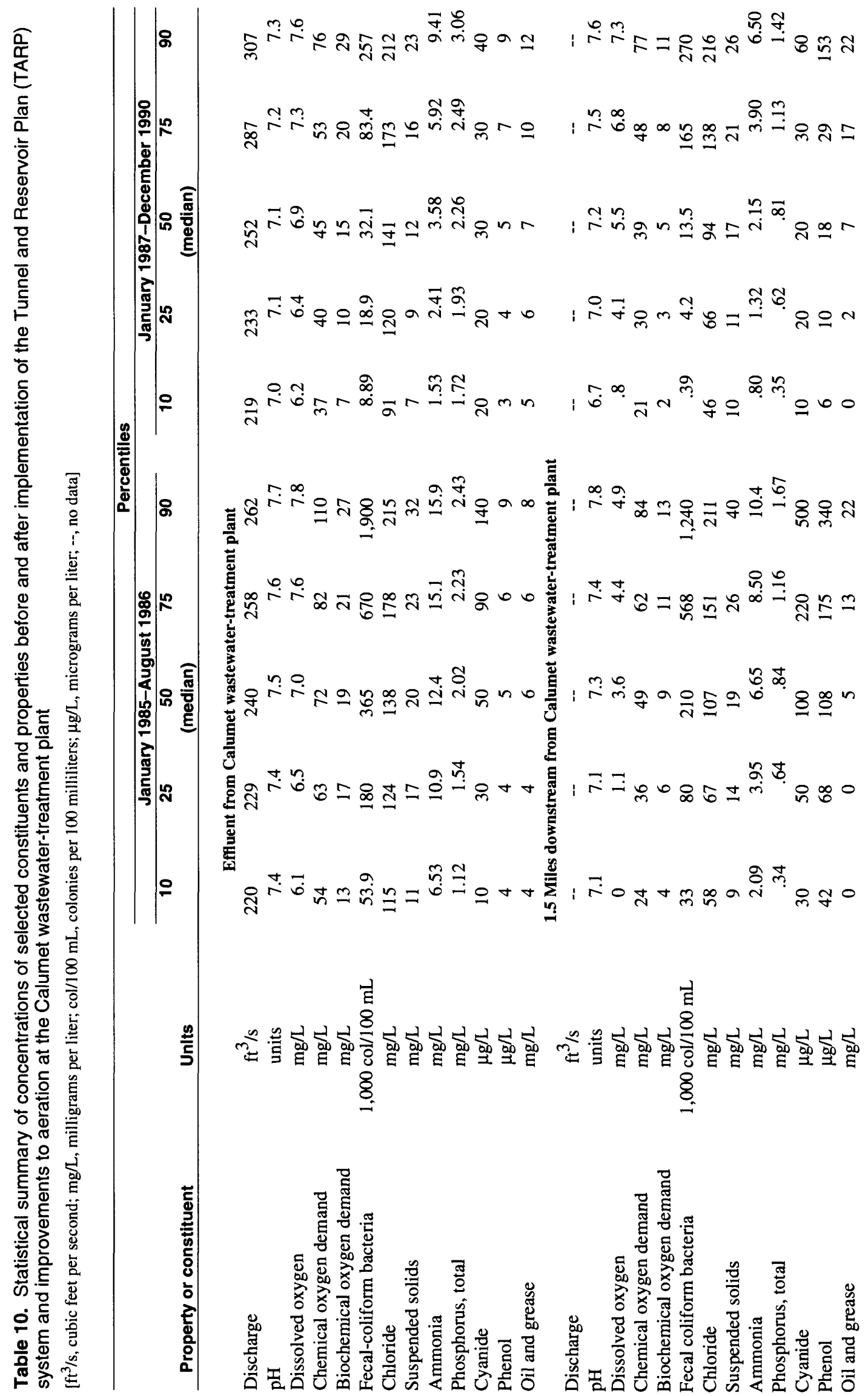




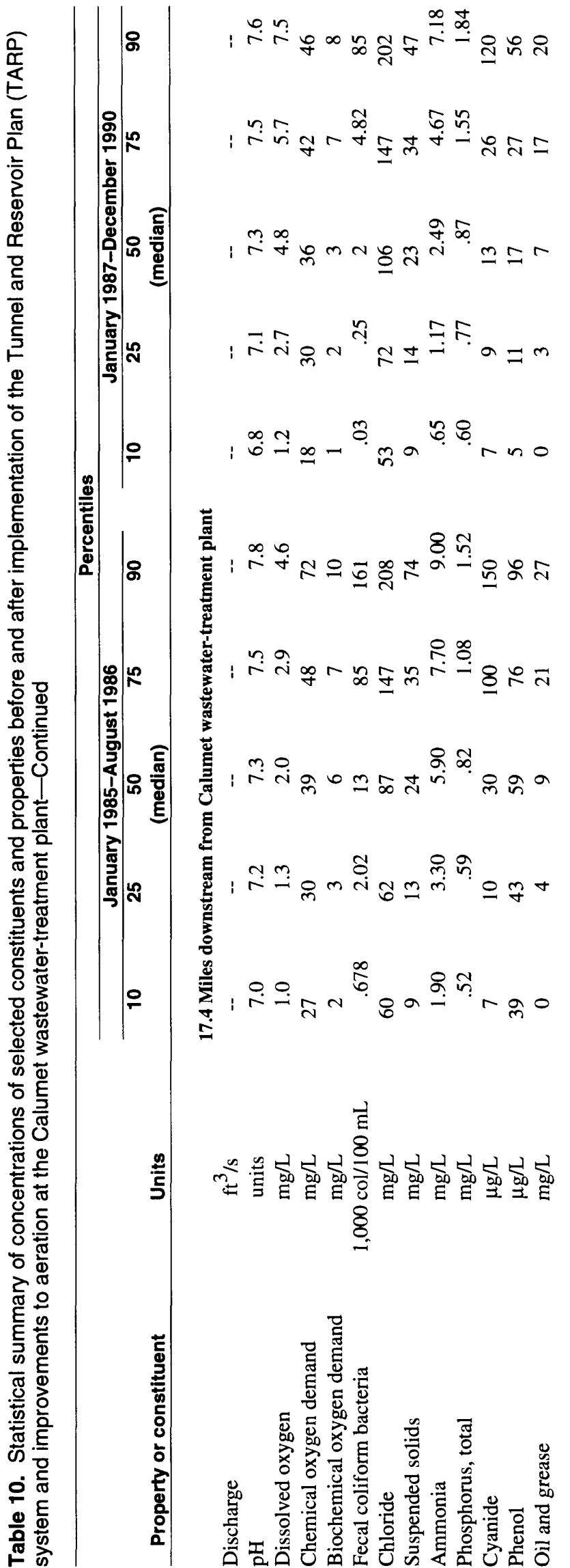

data collected for regional-scale, spatially oriented water-quality assessments.

Fish-community structure was summarized with DCA, a multivariate ordination technique, and with the Alternate Index of Biotic Integrity (AIBI). The AIBI is a modification of the IBI (Karr and others, 1986) that was specifically designed for Illinois streams (Hite and Bertrand, 1989). Relations between fish-community structure and water quality; streambed-sediment quality; and habitat in the Fox, Des Plaines, and Du Page River Basins in northeastern Illinois were examined with this technique to identify and describe some of the predominant environmental factors that affect the structure of fish communities within these river basins (Ruhl, 1995).

Fish communities were grouped with DCA and the AIBI. Streams in the predominantly agricultural Fox River Basin tended to have similar DCA scores, the highest AIBI scores, and relatively diverse fish communities that usually included several intolerant species. Streams in the more heavily urbanized Chicago, Calumet, Des Plaines, and Du Page River Basins tended to have lower AIBI scores and fish communities dominated by fewer, more tolerant species.

The relation between patterns in fish-community structure and patterns in the concentration of these constituents can be determined by comparing boxplots of the concentration of these constituents to boxplots of DCA and AIBI scores (fig. 28). The lowest DCA and AIBI scores, and the highest concentrations of these constituents are from sites in the most heavily urbanized basins (Chicago, Calumet, and Des Plaines River Basins). In contrast, the highest DCA and AIBI scores, and the lowest concentrations of these constituents are from stations in the agricultural Fox River Basin.

The results of the correlative and graphical analyses indicate that during the early 1980's fishcommunity structure within the study area was strongly related to patterns in water quality associated with differences between agricultural and urban land uses. Analyses of fish-community data clearly indicate that water-quality conditions in the urbanized parts of the study area were degraded relative to those in agricultural areas; for example, in highly urbanized areas, the fish community was entirely composed of extremely tolerant species, such as goldfish and common carp. The relations between fish-community structure and water quality were associated with assemblages of water-quality constituents. Results indicate a relation 


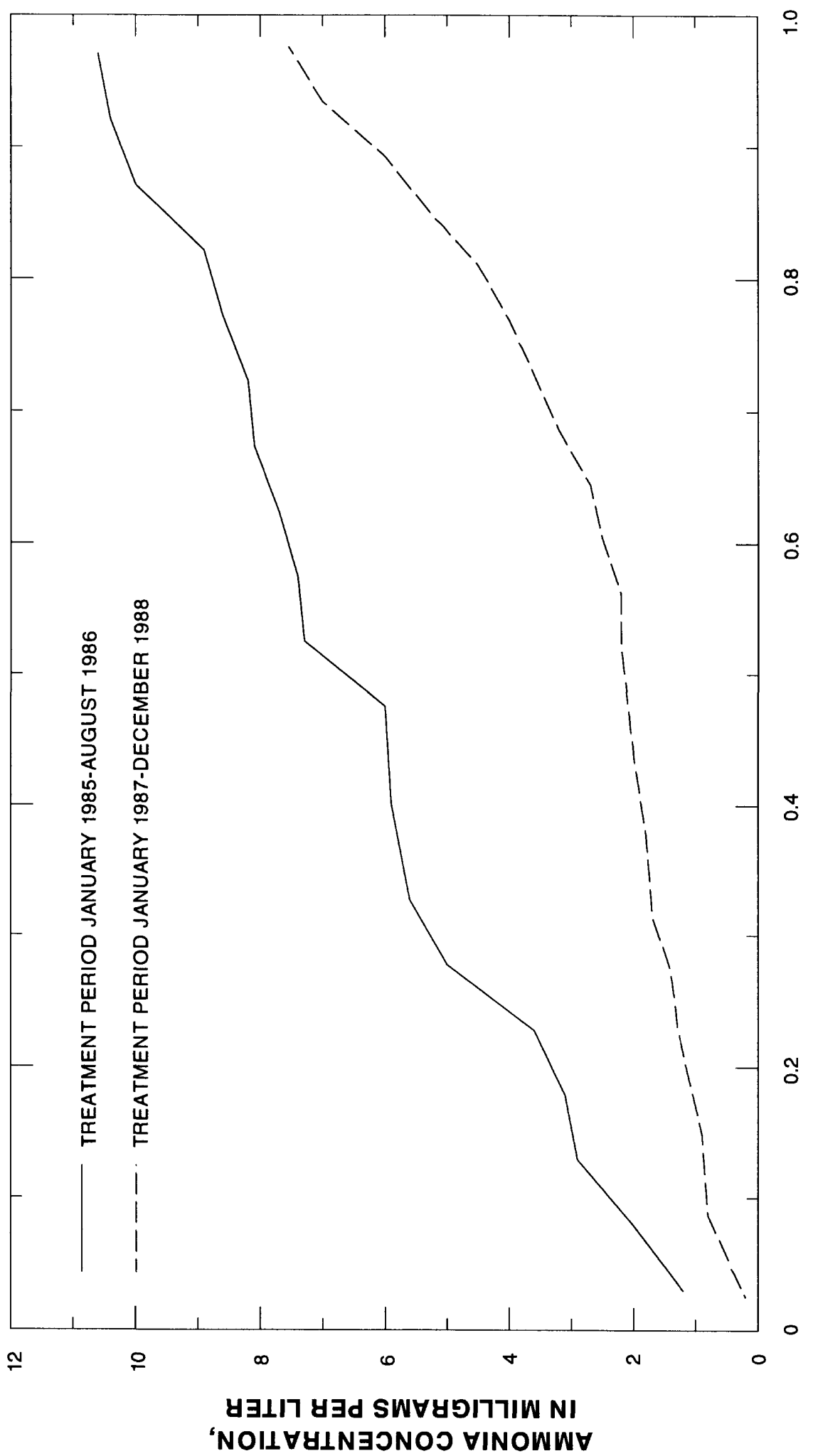

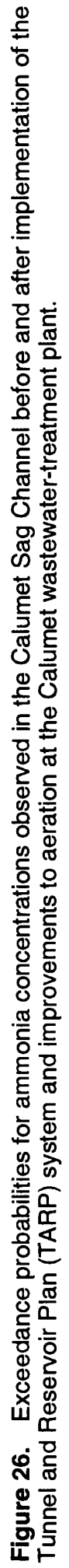




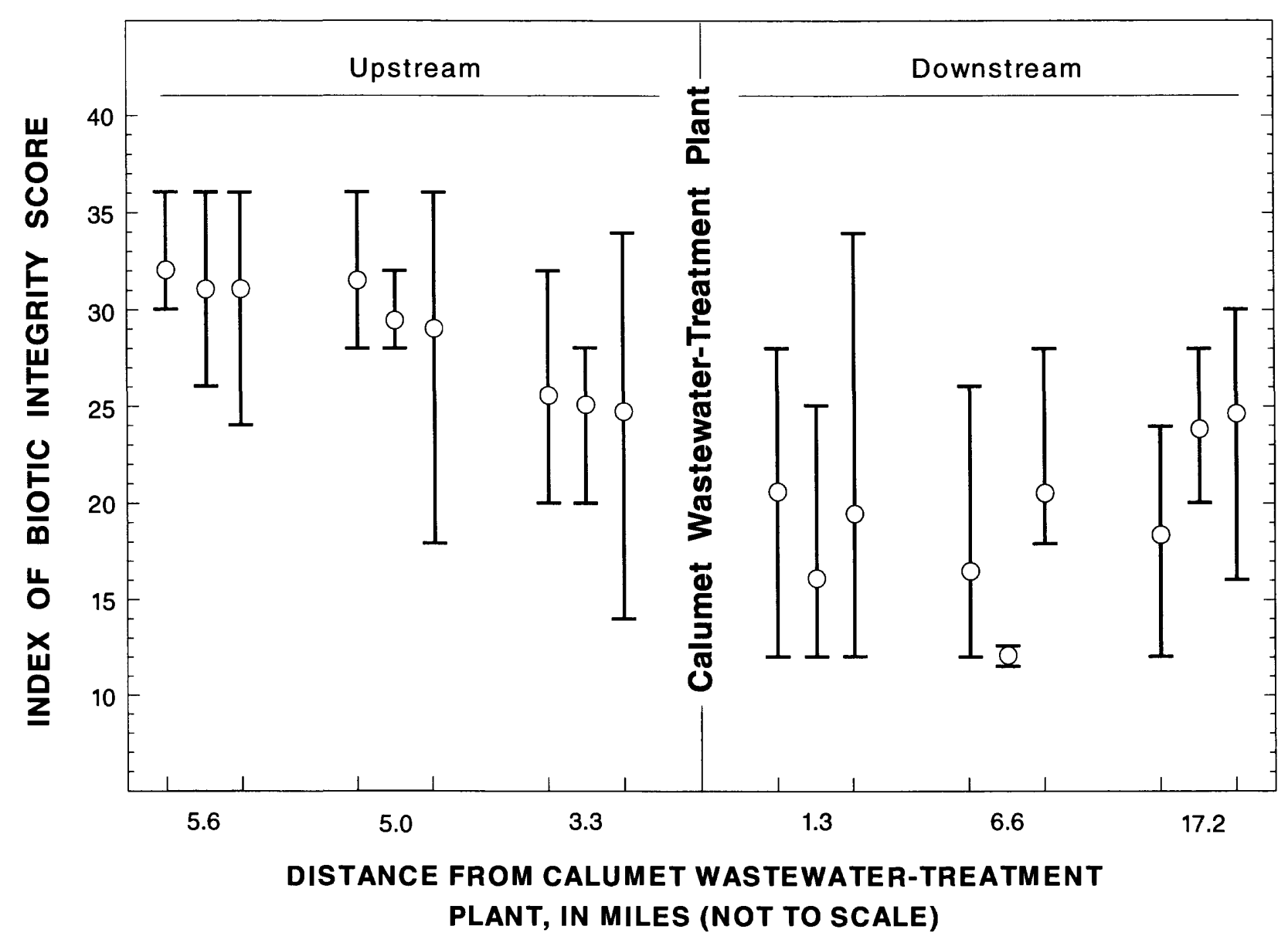

EXPLANATION

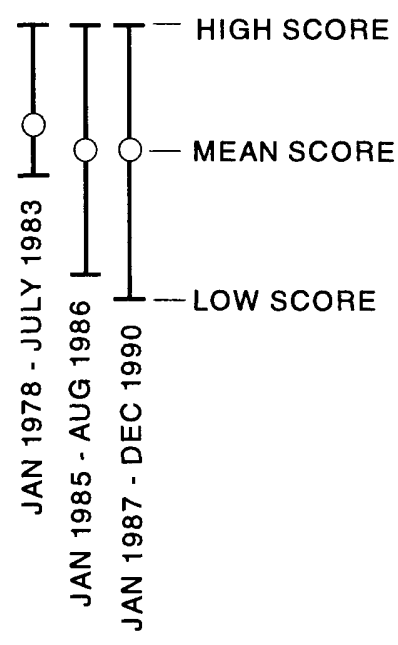

SCORE

58-60 Excellent

48-52 Good

40-44 Fair

28-34 Poor

12-22 Very poor

Figure 27. Index of biotic integrity (IBI) scores for six sites in the Calumet Sag Channel before and after implementation of the Tunnel and Reservoir Plan (TARP) system and improvements to aeration at the Calumet wastewater-treatment plant. 

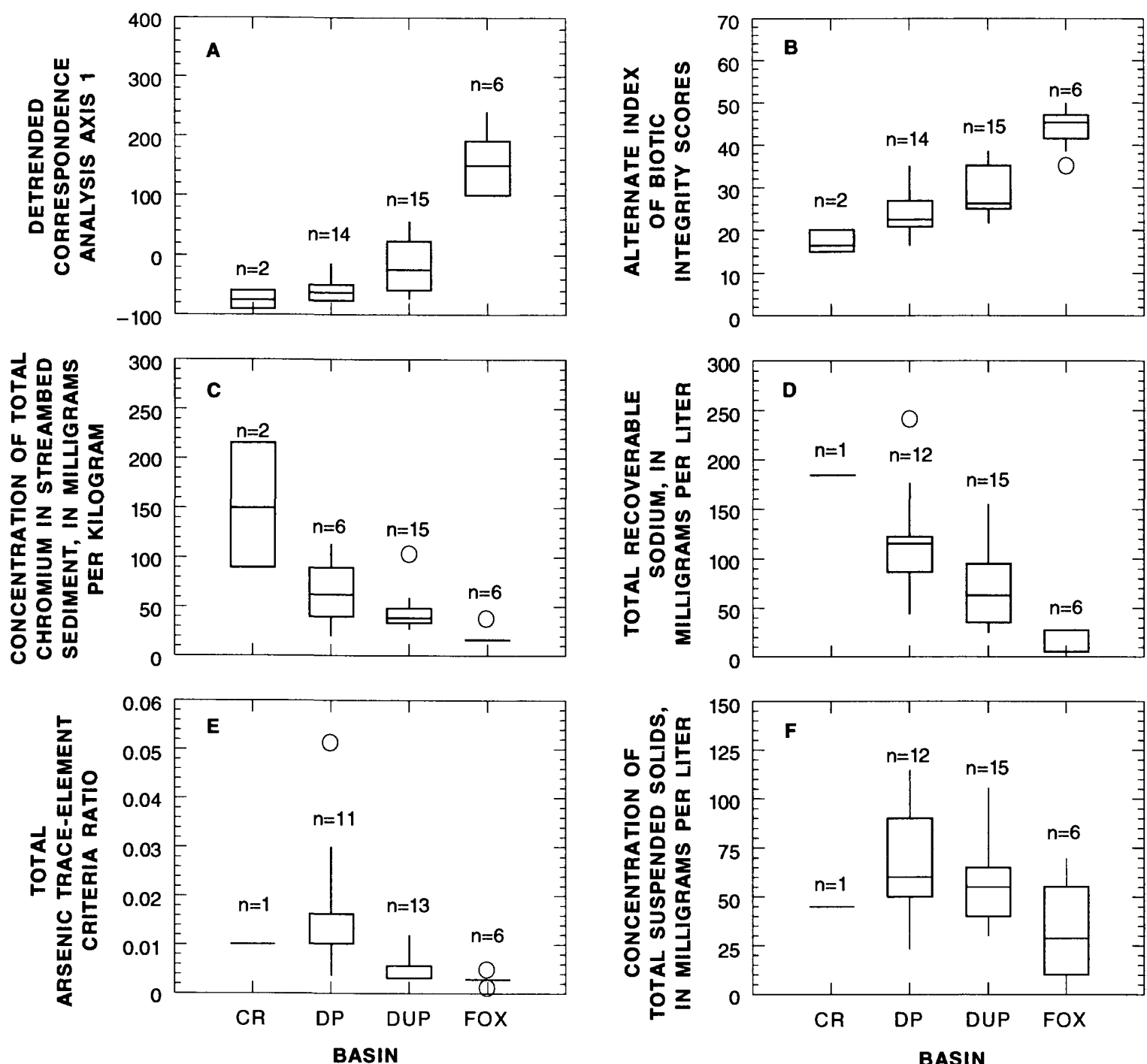

\section{EXPLANATION}

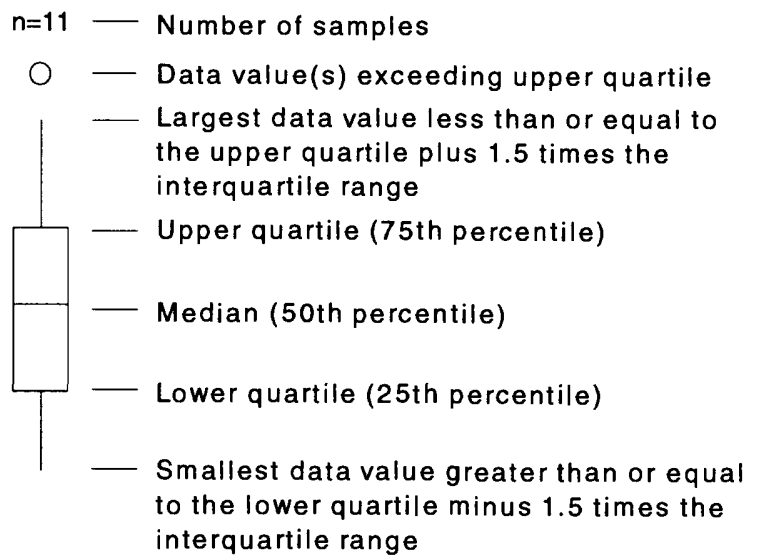

BASIN DESIGNATION

CR Chicago/Little Calumet River Basin

DP Des Plaines River Basin

DUP Du Page River Basin

FOX Fox River Basin

Figure 28. Detrended correspondence analyses (DCA) axis 1 site scales, Alternate Index of Biotic Integrity (AIBI) scores, concentrated total chromium in streambed sediments, concentration of total recoverable sodium, trace-element criteria ratios (TECR) for total arsenic, and concentration of total solids at sites in the Chicago/Little Calumet, Des Plaines, Du Page, and Fox River Basins. 
between the quality of the fish community and overall water-quality conditions.

USEPA acute water-quality criteria (U.S. Environmental Protection Agency, 1986) were exceeded for just four constituents: total cyanide, dissolved oxygen, total recoverable copper, and un-ionized ammonia (U.S. Environmental Protection Agency, 1986). Of the concentrations of constituents exceeding USEPA acute criteria, only the ratio of un-ionized ammonia to the USEPA criteria and the ratio of total recoverable copper to the USEPA criteria were significantly correlated with fish-community structure for wadable and nonwadable sites. For nonwadable sites, both ratios were significantly correlated with DCA and AIBI scores. For wadable sites, both ratios were significantly correlated with DCA scores, and the un-ionized ammonia criteria ratio was significantly correlated with AIBI scores.

Fish-community structure was not as strongly related to habitat as to water and streambed-sediment quality. Substrate particle size was weakly related to fish-community structure for wadable and nonwadable sites because the correlation coefficient was relatively small (wadable sites) or sampling was incomplete (nonwadable sites). For nonwadable sites, the percentage of the sampling reach containing logs and the percentage containing fish cover were weakly related to AIBI scores because sampling was incomplete. Fishcommunity structure for wadable sites was related to discharge, stream width, stream order, and current velocity but not as strongly as to water quality.

Results of analyses based on DCA and results of analyses based on AIBI are in general agreement. The similar DCA and AIBI results indicate that application of multivariate techniques for regional water-quality assessments is appropriate. Furthermore, multivariate techniques can be applied for validating the design of indices, such as the AIBI. Results from the two methods were similar probably because of the advanced development of the AIBI in Illinois. In other cases, however, where fully developed and tested biotic indices are not available, DCA may be utilized for design and testing.

Implications of results for the NAWQA study design are the following:

- Fish-community data are useful to identify long-term, low-level water-quality effects that would not be identified by comparing concentrations of constituents with water-quality criteria.
- Results from the DCA and AIBI methods were similar.

The NAWQA study of the upper Illinois River Basin provided data collected from several different media and for different groups of constituents. These data characterized not only the chemical quality of the water but also the quality of the streambed and suspended sediment; the concentration of selected constituents in tissue samples; and the composition and structure of fish, macroinvertebrate, and algal communities.

\section{SUMMARY}

A water-quality assessment of the 10,949 square miles upper Illinois River Basin during water years 1987-91 involved interpretation of available data, 4 years of intensive data collection including monthly sample collection at selected fixed-monitoring stations in the basin, and synoptic studies of selected waterquality constituents at many other stations and sites.

Discharges observed during the period of this study were greater than observed over the period of record but was not as large as during the period used for the analysis of available information (water years 1978-86). Precipitation observed during the period of this study was not appreciably different from that observed during the period of record for precipitation (1948-91) and the period used for the analysis of available information (water years 1978-86).

The number of exceedances of water-quality criteria for chromium, copper, lead, mercury, silver, and zinc in water was essentially the same at similar stations (mainly in the Des Plaines River Basin) between 1978-86 and 1987-90. Although the Chicago metropolitan area contains some of the most intensively urban and industrial land in the basin, concentrations of many of the trace inorganic constituents in water were below the minimum reporting level. Minimum reporting levels were just low enough to adequately classify concentrations that exceeded water-quality criteria.

In general, the spatial distribution of major and trace inorganic constituents in the upper Illinois River Basin indicated enrichment from the urban areas. For water and sediment, a large signature for many trace inorganic constituents was observed in the Chicago metropolitan area, mainly from the Des Plaines River Basin and continuing down the Illinois River. Loads of trace inorganic constituents in water were 2-13 times 
greater from the Chicago metropolitan area than from rural areas in the upper Illinois River Basin.

Synoptic sampling for trace-inorganic constituents in fine-grained streambed sediments indicated two distinctive patterns of enrichment: (1) Enrichment in the Chicago metropolitan area and in streams draining the urban area, relative to rural areas; and (2) enrichment in high-order streams (main stems), relative to low-order stream (tributaries).

Concentrations of cadmium, mercury, nickel, selenium, and zinc appeared to be relatively enriched in biota from rural and urban stations scattered across the upper Illinois River Basin compared to other river basins in Illinois. Biota from some urban stations in the basin were enriched with respect to several elements. Relatively high concentrations of cadmium, chromium, copper, nickel, and lead were detected in biota from sites in the urban Chicago and Calumet Rivers.

Correlation analysis between element concentrations in tissues and other components in this study emphasizes that water and sediment cannot be used as surrogates for biota; concentrations in biota cannot presently be determined from concentrations in these components; and because of bioaccumulation, concentrations of trace elements in biota must be measured directly. It is clear that a combination of information from various components is optimum for achieving a more complete understanding of water quality in the upper Illinois River Basin.

Results of pesticide sampling in 1988 and 1989 indicate that bromacil, diazinon, malathion, prometone, and simazine were primarily urban related. Agricultural-related pesticides included alachlor, atrazine, cyanazine, metolachlor, and metribuzin. Concentrations of atrazine exceeded the maximum contaminant level (MCL) for drinking water in agricultural and urban areas. The atrazine breakdown products, desethylatrazine and desisopropylatrazine, were detected in 100 and 94 percent of samples, respectively.

Chloroform was the most commonly detected volatile organic compound, which was present in 42 percent of the samples collected during a 1988 synoptic survey. The next most commonly detected compounds - tetrachloroethylene and 1,1,1-trichloroethane-each were detected in 29 percent of the samples. With one exception, all stations at which more than one compound was detected were in the vicinity of a point source.
Phenols were detected most frequently in the Des Plaines River Basin with 62 percent of the total detections in the upper Illinois River Basin. Median phenol concentrations measured from samples taken during the Metropolitan Water Reclamation District of Greater Chicago 1989 survey decreased with distance downstream from Chicago. Phenol concentrations never exceeded the general-use and secondarycontact standards of 100 and 300 micrograms per liter $(\mu \mathrm{g} / \mathrm{L})$, respectively. Pentachlorophenols were detected most frequently in the Des Plaines River Basin. Pentachlorophenol concentrations detected at the Illinois River at Marseilles, Ill. (map reference number 76), between 1981 and 1992 showed a decrease beginning in 1987 , which was most likely associated with the ban on the use of pentachlorophenols on nonwood products by the Illinois Environmental Protection Agency in 1987.

A breakdown product of the organochlorine pesticide dichloro-diphenyl-trichloroethane (DDT), $p, p$ '-DDE, was the most commonly detected organic compound in biota in 1989 and 1990. Concentrations of polychlorinated biphenyls (PCB's), $p, p^{\prime}$-DDE, $p, p^{\prime}-\mathrm{DDD}$, and dieldrin in biota had the most variability and highest median. In the nine fish-fillet samples collected in 1989, exceedances of U.S. Environmental Protection Agency fish-tissue concentrations were noted for $p, p^{\prime}$-DDE in all nine fillets and for dieldrin in five of the nine fillets.

During low-flow conditions, almost all of the total nitrogen load measured in the upper Illinois River Basin was in the Des Plaines River Basin. The majority of this load was from the Chicago Sanitary and Ship Canal. The Chicago Sanitary and Ship Canal also was observed to carry most of the ammonia and phosphorus loads during low-flow conditions.

Nutrient concentrations in the upper Illinois River Basin generally were higher than concentrations typically found in natural waters. Nutrient concentrations in urban areas, particularly in the Des Plaines River Basin, generally were higher than in other areas of the upper Illinois River Basin. The Des Plaines River Basin contributed approximately 41 percent of the total nitrogen load to the upper Illinois River Basin, whereas the Kankakee River and Fox River Basins contributed about 39 and 13 percent of the total load, respectively. About 30 percent of the total nitrogen load in the upper Illinois River Basin was measured in the Chicago Sanitary and Ship Canal, Ill. (map reference number 55 ). 
Although most of the nitrogen in the upper Illinois River Basin streams was in the form of nitrate, ammonia concentrations indicate differences between stations draining urban and rural areas. Concentrations of ammonia were higher at stations with urban drainage areas and substantial upstream inputs from wastewater-treatment plants. All ammonia concentrations higher than $10 \mathrm{mg} / \mathrm{L}$ were detected in the Des Plaines and Du Page Rivers.

Median dissolved oxygen concentrations at the fixed-monitoring stations ranged from $3.4 \mathrm{mg} / \mathrm{L}$ at the Chicago Sanitary and Ship Canal at Romeoville, Ill. (map reference number 55), to $12.2 \mathrm{mg} / \mathrm{L}$ at the Fox River at Dayton, Ill. (map reference number 99). Dissolved oxygen concentrations measured during a 1988 synoptic sampling did not meet the State water-quality standards at 76 percent of the stations sampled. In the Kankakee River Basin, 10 of the 17 stations contained water with dissolved oxygen concentrations less than $5 \mathrm{mg} / \mathrm{L}$, including the site with the lowest measured concentration $(1.85 \mathrm{mg} / \mathrm{L})$. In contrast, dissolved oxygen concentrations in water at all stations measured in the Fox River Basin were greater than $5 \mathrm{mg} / \mathrm{L}$.

Bacteria densities greater than water-quality criteria and standards were observed at all of the fixed-monitoring stations, but densities greater than water-quality criteria and standards were observed more often at stations in the Des Plaines River Basin. Densities of all the samples analyzed for Escherichia Coli from the Des Plaines River at Riverside, Ill. (map reference number 40 ), were greater than the singlesample criteria for infrequently used full-body contact recreation. Approximately 73 percent of the samples collected from the Chicago Sanitary and Ship Canal at Romeoville, Ill. (map reference number 55), contained densities exceeding this criteria.

Significant downward trends in fecal-coliform bacteria densities from 1978 to 1990 were observed at three fixed-monitoring stations draining largely agricultural basins. No significant trends were observed at stations in urban areas for 1978-90.

Fecal-coliform bacteria densities increased at sampling sites downstream from the Calumet wastewater-treatment plant after disinfection of the effluent was discontinued. However, these increases were limited to the vicinity of the wastewater-treatment plant. No change in bacteria densities was observed at sampling sites farther than 7 miles downstream, although effluent compose about 45 to 75 percent of the streamflow.
Significant changes in concentrations of suspended solids and other constituents were observed in water samples from the effluent of the wastewatertreatment plant and from the Calumet Sag Channel after overflow from combined sewers began discharging to Chicago's Tunnel and Reservoir Plan (TARP) system and aeration was improved. Median concentrations of biochemical oxygen demand (BOD) and ammonia decreased in the effluent and at all downstream sites. Changes in fish-community structure and population, as summarized by the Index of Biotic Integrity (IBI), did not indicate changes following changes in wastewater-treatment practices. Results from the analysis of changes in water quality following changes in wastewater-treatment practices indicate that current monitoring programs, although sufficient for their intended purposes, need to be enhanced for largescale retrospective water-quality assessments. The lack of discharge data from the stream-monitoring program prevented constituent load and mass transport analyses.

Fish communities were grouped by river basin by Detrended Correspondence Analysis (DCA) and the Alternate Index of Biotic Integrity (AIBI). Streams in the predominantly agricultural Fox River Basin tended to have similar DCA scores, the highest AIBI scores, and relatively diverse fish communities that usually included several intolerant species. Streams in the more heavily urbanized Chicago, Calumet, Des Plaines, and Du Page River Basins tended to have lower DCA and AIBI scores, and fish communities dominated by fewer, more tolerant species. Analyses of fish-community data clearly indicate that water-quality conditions in the urbanized parts of the study area were degraded relative to those in agricultural areas. For example, in highly urbanized areas, the fish community was entirely composed of extremely tolerant species, such as goldfish and common carp.

\section{REFERENCES}

Blanchard, S.F., and Schmidt, A.R., eds., in press, Surfacewater-quality assessment of the upper Illinois River Basin in Illinois, Indiana, and Wisconsin-Analysis of available water-quality data through 1986 :

U.S. Geological Survey Open-File Report 94-30.

Colman, J.A., and Sanzolone, R.F., 1991, Surface-waterquality assessment of the upper Illinois River Basin in Illinois, Indiana, and Wisconsin-Geochemical data for fine-fraction streambed sediment from high- and low-order streams, 1987: U.S. Geological Survey Open-File Report 90-571, 108 p. 
1992, Geochemical characterization and enrichment assessment of streambed sediment in the upper Illinois River Basin: Water Resources Bulletin, v. 28, no. 5, p. 1-18.

Commoner, B., 1979, Chemical carcinogens in the environment, in Keith, L.H., ed., Identification and analysis of organic pollutants in water: Ann Arbor, Ann Arbor Science, p. 49-71.

Eisler, R., 1988a, Arsenic hazards to fish, wildlife, and invertebrates-A synoptic review: U.S. Fish and Wildlife Service Biological Report 85(1.12), $92 \mathrm{p}$.

Fitzpatrick, F.A., and Colman, J.A., 1993, Surface-waterquality assessment of the upper Illinois River Basin in Illinois, Indiana, and Wisconsin-Data on manmade nonagricultural volatile and semivolatile organic chemicals in water, May 1988 through March 1990:

U.S. Geological Survey Open-File Report 92-467, $73 \mathrm{p}$.

Fitzpatrick, F.A., Scudder, B.C., Crawford, J.K., Sieverling, J.B., and Schmidt, A.R., with contributions from Colman, J.A., Crawford, C.G., and Sullivan, D.J., 1995, Surface water-quality assessment of the upper Illinois River Basin in Illinois, Indiana, and Wisconsin-Major and trace elements in water, sediment, and biota, 1978 through 1990:

U.S. Geological Survey Water-Resources Investigations Report 95-4045, 254 p.

Gauch, 1982, Multivariate analysis in community ecology: New York, Cambridge University Press, 298 p.

Ginsberg, Robert, and Osborne, John, 1984, Pesticides, cities, and you: Citizens for a Better Environment, Environmental Review, $2 \mathrm{p}$.

Gross, D.L., and Berg, R.C., 1981, Geology of the Kankakee River system, in Kankakee County, Illinois: Illinois State Geological Survey Environmental Geology Notes $92,80 \mathrm{p}$.

Helsel, D.R., and Cohn, T.A., 1988, Estimation of descriptive statistics for multiply censored water quality data: Water Resources Research, v. 24, p. 1997-2004.

Hem, J.D., 1985, Study and interpretation of the chemical characteristics of natural water: U.S. Geological Survey Water-Supply Paper 2254, 263 p.

Hite, R.L., and Bertrand, B.A., 1989, Biological stream characterization (BSC) - A biological assessment of Illinois stream quality: special report \# 13 of the Illinois State Water Plan Task Force, Springfield, Illinois, Illinois Environmental Protection Agency Division of Water Pollution Control, IEPA/WPC/89-275, 42 p.

Illinois Environmental Protection Agency, 1979, Water quality management plan, Volume II, Assessment of water quality; Surface water-Streams and lakes; Ground water: Illinois Environmental Protection Agency, $100 \mathrm{p}$.
1988, Illinois water-quality report, 1986-1987: Illinois Environmental Protection Agency report IEPA/WPC/88-002, 305 p.

Karr, J.R., Fausch, K.D., Angermeier, P.L., Yant, P.R., and Schlosser, I.J., 1986, Assessing biological integrity in running waters-A method and its rationale:

Champaign, Ill., Illinois Natural History Survey Special Publication 5, $28 \mathrm{p}$.

Koplin, D.W., Burkart, M.R., and Thuman, M.E., 1994, Herbicides and nitrate in near-surface aquifers in the midcontinental United States, 1991: U.S. Geological Survey Water-Supply Paper 2413, p. 2-3.

Mades, D.M., 1987, Surface-water-quality assessment of the upper Illinois River Basin in Illinois, Indiana, and Wisconsin-project description: U.S. Geological Survey Open-File Report 87-473, 35 p.

Marron, D.C., and Blanchard, S.F., 1995, Surface-waterquality assessment of the upper Illinois River Basin in Illinois, Indiana, and Wisconsin-Cross-sectional and depth variation of water-quality constituents and properties in the upper Illinois River Basin, 1987-88:

U.S. Geological Survey Water-Resources Investigations Report 95-4021, $19 \mathrm{p}$.

Mattraw, H.C., Jr., Wilber, W.G., and Alley, W.M., 1989, Quality-assurance plan for the pilot National WaterQuality Assessment program: U.S. Geological Survey Open-File Report 88-726, 21 p.

Moore, J.W., and Ramamoorthy, S., 1984, Organic chemicals in natural waters-Applied monitoring and impact assessment: New York, Springer-Verlag, 289 p.

Pike, D.R., Knake, E.L., Kuhlman, D.E., McGlamery, M.D., and Pataky, N.R., 1990, Pesticide use in Illinois -Results of a 1988 survey of major crops: University of Illinois at Urbana-Champaign, $26 \mathrm{p}$.

Moody, D.W., Chase, E.B., Aronson, D.A., comps., 1986, National water summary 1985-Hydrologic events and surface-water resources: U.S. Geological Survey Water-Supply Paper 2300, 506 p.

Mueller, D.K., and Helsel, D.R., 1996, Nutrients in the nation's waters-Too much of a good thing?: U.S. Geological Survey Circular 1136, 24 p.

Ruhl, P.M., 1995, Surface-water-quality assessment of the upper Illinois River Basin in Illinois, Indiana, and Wisconsin-Analysis of relations between fish community structure and environmental conditions in the Fox, Des Plaines, and Du Page River Basins in Illinois, 1982-84: U.S. Geological Survey Water-Resources Investigations Report 94-4094, 50 p.

Schmitt, C.J., Zajicek, J.L., and Peterman, P.H., 1990, National Contaminant Biomonitoring ProgramResidues of organochlorine chemicals in U.S. freshwater fish, 1976-1984: Archives of Environmental Contamination and Toxicology, v. 19, p. 748-781.

Smith, R.A., Alexander, R.B., and Wolman, M.G., 1987, Analysis and interpretation of water-quality trends in 
major U.S. rivers, 1974-81: U.S. Geological Survey Water-Supply Paper 2307, 25 p.

Smith, R.A., Hirsch, R.M., and Slack, J.R., 1982, A study of trends in total phosphorus measurements at NASQAN stations: U.S. Geological Survey Water-Supply Paper 2190, $34 \mathrm{p}$.

Smith, J.A., Witkowski, P.J., and Fusillo, T.V., 1988, Manmade organic compounds in the surface waters of the United States-A review of current understanding: U.S. Geological Survey Circular 1007, 92 p.

Steffeck, D.W., and Striegl, R.G., 1989, An inventory and evaluation of biological investigations that relate to stream-water quality in the upper Illinois River Basin of Illinois, Indiana, and Wisconsin: U.S. Geological Survey Water-Resources Investigations Report 89-4041, 54 p.

Sullivan, D.J., and Blanchard, S.F., 1994, Surface-waterquality assessment of the upper Illinois River Basin in Illinois, Indiana, and Wisconsin-Fixed-station network, water-quality data, April 1987 to September 1990: U.S. Geological Survey Open-File Report 91-175, $80 \mathrm{p}$.

Sullivan, D.J., Stinson, T.W., Crawford, K., and Schmidt, A.R, in press, Surface water-quality assessment of the upper Illinois River Basin in Illinois, Indiana, and Wisconsin-Pesticides and other synthetic organic compounds in water, sediment, and biota, 1978-90: U.S. Geological Survey Water-Resources Investigations Report 96-4135.

Sullivan, D.J., and Terrio, P.J., 1994, Surface-water-quality assessment of the upper Illinois River Basin in Illinois, Indiana, and Wisconsin-Data on agricultural organic compounds, nutrients, and sediment in water, April 1988-August 1990: U.S. Geological Survey Open-File Report 93-421, 61 p.

Ter Braak, C.J.F., 1986, Canonical correspondence analysis -A new eigenvector technique for multivariate direct gradient analysis: Ecology, v. 67, no. 5, p. 1167-1179.
1988, CANOCO-A FORTRAN program for canonical community ordination by [partial] [detrended] [canonical] correspondence analysis, principal components analysis, and redundancy analysis (version 2.1): Wageningen, The Netherlands, Ministry of Agriculture and Fisheries Agricultural Mathematics Group, $95 \mathrm{p}$.

Terrio, P.J., 1994a, Surface-water-quality assessment of the upper Illinois River Basin in Illinois, Indiana, and Wisconsin: Nutrients, dissolved oxygen, and fecalindicator bacteria in surface water, April 1987 through August 1990: U.S. Geological Survey Water-Resources Investigations Report 95-4005, 79 p.

1994b, Surface-water-quality assessment of the upper Illinois River Basin in Illinois, Indiana, and Wisconsin-Relation of changes in wastewatertreatment practices to changes in stream-water quality during 1978-88 in the Chicago area, Illinois, and implications for regional and national water-quality assessments: U.S. Geological Survey Water-Resources Investigations Report 93-4188, 56 p.

U.S. Environmental Protection Agency, 1986, Quality criteria for water, 1986: U.S. Environmental Protection Agency Report No. 440/5-86-001, [about] 400 p. 1992a, National study of chemical residues in fish: Washington, D.C., EPA 823-R-92-008 a,b. 1992b, Toxic substances spreadsheet (12/92): Atlanta, Ga., [variously paged].

Woolson, E.A., ed., 1975, Arsenical pesticides: American Chemical Society Symposium Series, v. 7, 176 p.

Zogorski, J.S., Blanchard, S.F., Romack, R.D., and Fitzpatrick, F.A., 1990, Availability and suitability of municipal wastewater information for use in a national water-quality assessment-A case study of the upper Illinois River Basin in Illinois, Indiana, and Wisconsin: U.S. Geological Survey Open-File Report 90-375, $68 \mathrm{p}$. 


\section{APPENDIX}

- PAGE 57 foccows - 


\section{APPENDIX: SELECTED WATER-SAMPLING STATIONS INCLUDED IN THE WATER- QUALITY ASSESSMENT OF THE UPPER ILLINOIS RIVER BASIN, 1987-92}

[Lat, latitude; Long, longitude; ND, no data]

Phase of study: Pest2, Phase II (1990) pesticide-sampling site; VOC, sampling site for nonagricultural volatile and semivolatile organic compounds; Nutr, nutrient-sampling stie; Bio90, 1990 biology-sampling site; Bio89, 1989 biology-sampling site; Retro, analysis of available data; Ufix, fixed-monitoring station operated by the U.S. Geological Survey; Pest 1, Phase I (1988-89) pesticide-sampling site; Ifix, fixed-monitoring station operated by the Illinois Environmental Protection Agency

\begin{tabular}{|c|c|c|c|c|}
\hline $\begin{array}{c}\text { Map } \\
\text { reference } \\
\text { number } \\
\end{array}$ & $\begin{array}{l}\text { Station } \\
\text { number }\end{array}$ & Station name & $\begin{array}{l}\text { Drainage area } \\
\text { (square miles) }\end{array}$ & Phase of study \\
\hline \multicolumn{5}{|c|}{ Kankakee River Basin } \\
\hline 1 & 05515000 & $\begin{array}{l}\text { Kankakee River near North Liberty, Ind. } \\
\text { Lat } 41^{\circ} 33^{\prime} 50^{\prime \prime} \text { Long } 86^{\circ} 29^{\prime} 50^{\prime \prime}\end{array}$ & 174 & Pest2, VOC, Nutr \\
\hline 2 & 05515480 & $\begin{array}{l}\text { Mill Creek at Highway } 39 \text { near } \\
\text { Kingsford Heights, Ind. } \\
\text { Lat } 41^{\circ} 27^{\prime} 04^{\prime \prime} \text { Long } 86^{\circ} 44^{\prime} 14^{\prime \prime}\end{array}$ & ND & Bio90 \\
\hline 3 & 05515500 & $\begin{array}{l}\text { Kankakee River at Davis, Ind. } \\
\text { Lat } 41^{\circ} 24^{\prime} 00^{\prime \prime} \text { Long } 86^{\circ} 42^{\prime} 04^{\prime \prime}\end{array}$ & 537 & Pest2 \\
\hline 4 & 05516500 & $\begin{array}{l}\text { Yellow River at Plymouth, Ind. } \\
\text { Lat } 41^{\circ} 20^{\prime} 25^{\prime \prime} \text { Long } 86^{\circ} 18^{\prime} 16^{\prime \prime}\end{array}$ & 294 & Pest2 \\
\hline 5 & 05517000 & $\begin{array}{l}\text { Yellow River at Knox, Ind. } \\
\text { Lat } 41^{\circ} 18^{\prime} 10^{\prime \prime} \text { Long } 86^{\circ} 37^{\prime} 14^{\prime \prime}\end{array}$ & 435 & Pest2 \\
\hline 6 & 05517120 & $\begin{array}{l}\text { Pitner Ditch at State Highway } 8 \\
\text { near La Crosse, Ind. } \\
\text { Lat } 41^{\circ} 19^{\prime} 13^{\prime \prime} \text { Long } 86^{\circ} 50^{\prime} 48^{\prime \prime}\end{array}$ & ND & Bio90 \\
\hline 7 & 05517500 & $\begin{array}{l}\text { Kankakee River at Dunns Bridge, Ind. } \\
\text { Lat } 41^{\circ} 13^{\prime} 17^{\prime \prime} \text { Long } 86^{\circ} 57^{\prime} 52^{\prime \prime}\end{array}$ & 1,350 & Pest2, Nutr \\
\hline 8 & 05517530 & $\begin{array}{l}\text { Kankakee River near Kouts, Ind. } \\
\text { Lat } 41^{\circ} 15^{\prime} 14^{\prime \prime} \text { Long } 87^{\circ} 02^{\prime} 02\end{array}$ & 1,380 & Pest2 \\
\hline 9 & 05517725 & $\begin{array}{l}\text { Crooked Creek at } 100 \text { South Road near } \\
\text { Wanatah, Ind. } \\
\text { Lat } 41^{\circ} 25^{\prime} 12^{\prime \prime} \text { Long } 86^{\circ} 57^{\prime} 46^{\prime \prime}\end{array}$ & ND & Bio90 \\
\hline 10 & 05517890 & $\begin{array}{l}\text { Cobb Ditch near Kouts, Ind. } \\
\text { Lat } 41^{\circ} 20^{\prime} 19^{\prime \prime} \text { Long } 87^{\circ} 04^{\prime} 30^{\prime \prime}\end{array}$ & 30.3 & Pest2 \\
\hline 11 & 05518000 & $\begin{array}{l}\text { Kankakee River at Shelby, Ind. } \\
\text { Lat } 41^{\circ} 10^{\prime} 58^{\prime \prime} \text { Long } 87^{\circ} 20^{\prime} 33^{\prime \prime}\end{array}$ & 1,780 & Bio89, Pest2 \\
\hline 12 & 05519000 & $\begin{array}{l}\text { Singleton Ditch at Schneider, Ind. } \\
\text { Lat } 41^{\circ} 12^{\prime} 44^{\prime \prime} \text { Long } 87^{\circ} 26^{\prime} 44^{\prime \prime}\end{array}$ & 123 & Pest2 \\
\hline 13 & 05520150 & $\begin{array}{l}\text { Singleton Ditch at County Road } 52 \text { near } \\
\text { Illiana Heights, Ill. } \\
\text { Lat } 41^{\circ} 10^{\prime} 25^{\prime \prime} \text { Long } 87^{\circ} 34^{\prime} 32^{\prime \prime}\end{array}$ & 242 & Nutr \\
\hline 14 & 05520500 & $\begin{array}{l}\text { Kankakee River at Momence, Ill. } \\
\text { Lat } 41^{\circ} 09^{\prime} 36^{\prime \prime} \text { Long } 87^{\circ} 40^{\prime} 07^{\prime \prime}\end{array}$ & 2,290 & $\begin{array}{l}\text { Retro, Ufix, Bio89, Bio90, } \\
\text { Pest2, VOC, Nutr }\end{array}$ \\
\hline
\end{tabular}




\section{APPENDIX: SELECTED WATER-SAMPLING STATIONS INCLUDED IN THE WATER- QUALITY ASSESSMENT OF THE UPPER ILLINOIS RIVER BASIN, 1987-92-CONTINUED}

\begin{tabular}{|c|c|c|c|c|}
\hline $\begin{array}{l}\text { Map } \\
\text { reference } \\
\text { number } \\
\end{array}$ & $\begin{array}{c}\text { Station } \\
\text { number }\end{array}$ & Station name & $\begin{array}{r}\text { Drainage area } \\
\text { (square miles) }\end{array}$ & Phase of study \\
\hline \multicolumn{5}{|c|}{ Kankakee River Basin - Continued } \\
\hline 15 & 05521000 & $\begin{array}{l}\text { Iroquois River at Rosebud, Ind. } \\
\text { Lat } 41^{\circ} 02^{\prime} 00^{\prime \prime} \text { Long } 87^{\circ} 10^{\prime} 49^{\prime \prime}\end{array}$ & 35.6 & Pest2 \\
\hline 16 & 05522500 & $\begin{array}{l}\text { Iroquois River at Rensselaer, Ind. } \\
\text { Lat } 40^{\circ} 56^{\prime} 00^{\prime \prime} \text { Long } 87^{\circ} 07^{\prime} 44^{\prime \prime}\end{array}$ & 203 & Pest2 \\
\hline 17 & 05523000 & $\begin{array}{l}\text { Bice Ditch near South Marion, Ind. } \\
\text { Lat } 40^{\circ} 52^{\prime} 00^{\prime \prime} \text { Long } 87^{\circ} 05^{\prime} 32^{\prime \prime}\end{array}$ & 21.8 & Pest1, VOC \\
\hline 18 & 05523500 & $\begin{array}{l}\text { Slough Creek near Collegeville, Ind. } \\
\text { Lat } 40^{\circ} 53^{\prime} 30^{\prime \prime} \text { Long } 87^{\circ} 09^{\prime} 17^{\prime \prime}\end{array}$ & 83.7 & Nutr \\
\hline 19 & 05524500 & $\begin{array}{l}\text { Iroquois River near Foresman, Ind. } \\
\text { Lat } 40^{\circ} 52^{\prime} 14^{\prime \prime} \text { Long } 87^{\circ} 18^{\prime} 24^{\prime \prime}\end{array}$ & 449 & Pest2 \\
\hline 20 & 05525000 & $\begin{array}{l}\text { Iroquois River at Iroquois, Ill. } \\
\text { Lat } 40^{\circ} 49^{\prime} 25^{\prime \prime} \text { Long } 87^{\circ} 34^{\prime} 55^{\prime \prime}\end{array}$ & 686 & Retro, Ifix, Pest2 \\
\hline 21 & 05525290 & $\begin{array}{l}\text { Sugar Creek near Stockland, Ill. } \\
\text { Lat } 40^{\circ} 39^{\prime} 01^{\prime \prime} \text { Long } 87^{\circ} 31^{\prime} 34^{\prime \prime}\end{array}$ & 85.1 & Nutr \\
\hline 22 & 05525500 & $\begin{array}{l}\text { Sugar Creek at Milford, Ill. } \\
\text { Lat } 40^{\circ} 37^{\prime} 50^{\prime \prime} \text { Long } 87^{\circ} 43^{\prime} 25^{\prime \prime}\end{array}$ & 446 & $\begin{array}{l}\text { Retro, Ifix, Pest1, Pest2, } \\
\text { VOC, Nutr }\end{array}$ \\
\hline 23 & 05525540 & $\begin{array}{l}\text { Iroquois River near Watseka, Ill. } \\
\text { Lat } 40^{\circ} 48^{\prime} 44^{\prime \prime} \text { Long } 87^{\circ} 48^{\prime} 25^{\prime \prime}\end{array}$ & ND & Bio89, VOC, Nutr \\
\hline 24 & 05525555 & $\begin{array}{l}\text { Spring Creek near Delrey, Ill. } \\
\text { Lat } 40^{\circ} 37^{\prime} 49^{\prime \prime} \text { Long } 88^{\circ} 00^{\prime} 22^{\prime \prime}\end{array}$ & 47.4 & Bio90 \\
\hline 25 & 05525570 & $\begin{array}{l}\text { Spring Creek at Road } 730 \text { East near } \\
\text { Onarga, Ill. } \\
\text { Lat } 40^{\circ} 41^{\prime} 52^{\prime \prime} \text { Long } 87^{\circ} 59^{\prime} 09^{\prime \prime}\end{array}$ & 146 & Bio90 \\
\hline 26 & 05525600 & $\begin{array}{l}\text { Spring Creek near Gilman, Ill. } \\
\text { Lat } 40^{\circ} 46^{\prime} 08^{\prime \prime} \text { Long } 87^{\circ} 54^{\prime} 02^{\prime \prime}\end{array}$ & 221 & Nutr \\
\hline 27 & 05525680 & $\begin{array}{l}\text { Langan Creek at Road } 1300 \text { East near } \\
\text { Clifton, Ill. } \\
\text { Lat } 40^{\circ} 58^{\prime} 08^{\prime \prime} \text { Long } 87^{\circ} 53^{\prime} 04^{\prime \prime}\end{array}$ & 94.2 & Bio90 \\
\hline 28 & 05526000 & $\begin{array}{l}\text { Iroquois River near Chebanse, Ill. } \\
\text { Lat } 41^{\circ} 00^{\prime} 32^{\prime \prime} \text { Long } 87^{\circ} 49^{\prime} 27^{\prime \prime}\end{array}$ & 2,090 & $\begin{array}{c}\text { Retro, Ufix, Bio90, Pest2, } \\
\text { VOC, Nutr }\end{array}$ \\
\hline 29 & 05526130 & $\begin{array}{l}\text { Kankakee River near Bourbonnais, Ill. } \\
\text { Lat } 41^{\circ} 09^{\prime} 08^{\prime \prime} \text { Long } 87^{\circ} 54^{\prime} 49^{\prime \prime}\end{array}$ & 4,630 & VOC, Nutr \\
\hline 30 & 05526410 & $\begin{array}{l}\text { Rock Creek at Highway } 102 \text { near } \\
\text { Deselm, Ill. } \\
\text { Lat } 41^{\circ} 12^{\prime} 23^{\prime \prime} \text { Long } 87^{\circ} 59^{\prime} 05^{\prime \prime}\end{array}$ & 120 & Nutr \\
\hline
\end{tabular}




\section{APPENDIX: SELECTED WATER-SAMPLING STATIONS INCLUDED IN THE WATER- QUALITY ASSESSMENT OF THE UPPER ILLINOIS RIVER BASIN, 1987-92-CONTINUED}

\begin{tabular}{|c|c|c|c|c|}
\hline $\begin{array}{c}\text { Map } \\
\text { reference } \\
\text { number } \\
\end{array}$ & $\begin{array}{l}\text { Station } \\
\text { number }\end{array}$ & Station name & $\begin{array}{l}\text { Drainage area } \\
\text { (square miles) }\end{array}$ & Phase of study \\
\hline \multicolumn{5}{|c|}{ Kankakee River Basin-Continued } \\
\hline 31 & 05527500 & $\begin{array}{l}\text { Kankakee River near Wilmington, Ill. } \\
\text { Lat } 41^{\circ} 20^{\prime} 48^{\prime \prime} \text { Long } 88^{\circ} 11^{\prime} 11^{\prime \prime}\end{array}$ & 5,150 & Retro, Ifix, Pest2, VOC, Nutr \\
\hline 100 & 40544308 & $\begin{array}{l}\text { Iroquois River Above Slough Creek } \\
\text { near Rensselaer, Ind. } \\
\text { Lat } 40^{\circ} 54^{\prime} 43^{\prime \prime} \text { Long } 87^{\circ} 11^{\prime} 28^{\prime \prime}\end{array}$ & ND & Nutr \\
\hline 101 & 41161608 & $\begin{array}{l}\text { Reeves Ditch at State Road } 49 \text { near } \\
\text { Kouts, Ind. } \\
\text { Lat } 41^{\circ} 16^{\prime} 16^{\prime \prime} \text { Long } 87^{\circ} 01^{\prime} 31^{\prime \prime}\end{array}$ & ND & Nutr \\
\hline 102 & 41171408 & $\begin{array}{l}\text { Yellow River Above State Route } 8 \\
\text { near Knox, Ind. } \\
\text { Lat } 41^{\circ} 17^{\prime} 14^{\prime \prime} \text { Long } 86^{\circ} 32^{\prime} 56^{\prime \prime}\end{array}$ & ND & Nutr \\
\hline 103 & 41214708 & $\begin{array}{l}\text { Yellow River at North Hickory Road } \\
\text { near Inwood, Ind. } \\
\text { Lat } 41^{\circ} 21^{\prime} 47^{\prime \prime} \text { Long } 86^{\circ} 11^{\prime} 37^{\prime \prime}\end{array}$ & ND & Nutr \\
\hline \multicolumn{5}{|c|}{ Des Plaines River Basin } \\
\hline 32 & 05527800 & $\begin{array}{l}\text { Des Plaines River at Russell, Ill. } \\
\text { Lat } 42^{\circ} 29^{\prime} 22^{\prime \prime} \text { Long } 87^{\circ} 55^{\prime} 32^{\prime \prime}\end{array}$ & 123 & Retro, Ifix, VOC, Nutr \\
\hline 33 & 05528000 & $\begin{array}{l}\text { Des Plaines River near Gurnee, Ill. } \\
\text { Lat } 42^{\circ} 20^{\prime} 39^{\prime \prime} \text { Long } 87^{\circ} 56^{\prime} 18^{\prime \prime}\end{array}$ & 232 & Retro, Ifix, Nutr \\
\hline 34 & 05529000 & $\begin{array}{l}\text { Des Plaines River near Des Plaines, Ill. } \\
\text { Lat } 42^{\circ} 04^{\prime} 55^{\prime \prime} \text { Long } 87^{\circ} 53^{\prime} 25^{\prime \prime}\end{array}$ & 360 & Retro, Ifix, Nutr \\
\hline 35 & 05530590 & $\begin{array}{l}\text { Des Plaines River at Irving Park Road } \\
\text { near Schiller Park, Ill. } \\
\text { Lat } 41^{\circ} 57^{\prime} 11^{\prime \prime} \text { Long } 87^{\circ} 51^{\prime} 15^{\prime \prime}\end{array}$ & 444 & Retro, Ifix, \\
\hline 36 & 05530990 & $\begin{array}{l}\text { Salt Creek at Rolling Meadows, Ill. } \\
\text { Lat } 42^{\circ} 03^{\prime} 37^{\prime \prime} \text { Long } 88^{\circ} 00^{\prime} 59^{\prime \prime}\end{array}$ & 30.5 & Pest1, VOC \\
\hline 37 & 05531175 & $\begin{array}{l}\text { Salt Creek at Wood Dale, Ill. } \\
\text { Lat } 41^{\circ} 57^{\prime} 51^{\prime \prime} \text { Long } 87^{\circ} 59^{\prime} 03^{\prime \prime}\end{array}$ & 74.7 & VOC, Nutr \\
\hline 38 & 05531500 & $\begin{array}{l}\text { Salt Creek at Western Springs, Ill. } \\
\text { Lat } 41^{\circ} 49^{\prime} 35^{\prime \prime} \text { Long } 87^{\circ} 54^{\prime} 00^{\prime \prime}\end{array}$ & 115 & $\begin{array}{l}\text { Retro, Ifix, Bio89, Bio } 90 \\
\text { VOC, Nutr }\end{array}$ \\
\hline 39 & 05532000 & $\begin{array}{l}\text { Addison Creek at Bellwood, Ill. } \\
\text { Lat } 41^{\circ} 52^{\prime} 48^{\prime \prime} \text { Long } 87^{\circ} 52^{\prime} 07^{\prime \prime}\end{array}$ & 17.9 & Retro, Ifix, Pest1, VOC \\
\hline 40 & 05532500 & $\begin{array}{l}\text { Des Plaines River at Riverside, Ill. } \\
\text { Lat } 41^{\circ} 49^{\prime} 20^{\prime \prime} \text { Long } 87^{\circ} 49^{\prime} 15^{\prime \prime}\end{array}$ & 630 & $\begin{array}{c}\text { Ufix, Bio89, Bio90, VOC, } \\
\text { Nutr }\end{array}$ \\
\hline
\end{tabular}




\section{APPENDIX: SELECTED WATER-SAMPLING STATIONS INCLUDED IN THE WATER- QUALITY ASSESSMENT OF THE UPPER ILLINOIS RIVER BASIN, 1987-92-CONTINUED}

\begin{tabular}{|c|c|c|c|c|}
\hline $\begin{array}{c}\text { Map } \\
\text { reference } \\
\text { number }\end{array}$ & $\begin{array}{l}\text { Station } \\
\text { number }\end{array}$ & Station name & $\begin{array}{l}\text { Drainage area } \\
\text { (square mlles) }\end{array}$ & Phase of study \\
\hline \multicolumn{5}{|c|}{ Des Plaines River Basin—Continued } \\
\hline 41 & 05533020 & $\begin{array}{l}\text { Flag Creek at } 91 \text { st Street near } \\
\text { Willow Springs, Ill. } \\
\text { Lat } 41^{\circ} 43^{\prime} 26^{\prime \prime} \text { Long } 87^{\circ} 54^{\prime} 28^{\prime \prime}\end{array}$ & 18.3 & Nutr \\
\hline 42 & 05534050 & $\begin{array}{l}\text { Des Plaines River at Lockport, Ill. } \\
\text { Lat } 41^{\circ} 35^{\prime} 47^{\prime \prime} \text { Long } 88^{\circ} 04^{\prime} 07^{\prime \prime}\end{array}$ & 700 & Retro, Ifix, VOC, Nutr \\
\hline 43 & 05534500 & $\begin{array}{l}\text { North Branch Chicago River at } \\
\text { Deerfield, Ill. } \\
\text { Lat } 42^{\circ} 09^{\prime} 10^{\prime \prime} \text { Long } 87^{\circ} 49^{\prime} 07^{\prime \prime}\end{array}$ & 19.7 & Retro, Ifix, \\
\hline 44 & 05535172 & $\begin{array}{l}\text { Skokie River at Happ Road at } \\
\text { Northfield, Ill. } \\
\text { Lat } 42^{\circ} 05^{\prime} 11^{\prime \prime} \text { Long } 87^{\circ} 46^{\prime} 00^{\prime \prime}\end{array}$ & 31.5 & Nutr \\
\hline 45 & 05536000 & $\begin{array}{l}\text { North Branch Chicago River at Niles, Ill. } \\
\text { Lat } 42^{\circ} 00^{\prime} 44^{\prime \prime} \text { Long } 87^{\circ} 47^{\prime} 45^{\prime \prime}\end{array}$ & 100 & $\begin{array}{c}\text { Retro, Ifix, Bio89, Bio90, } \\
\text { Nutr }\end{array}$ \\
\hline 46 & 05536107 & $\begin{array}{l}\text { North Shore Channel at Touhy Avenue } \\
\text { at Chicago, Ill. } \\
\text { Lat } 42^{\circ} 00^{\prime} 42^{\prime \prime} \text { Long } 87^{\circ} 42^{\prime} 37^{\prime \prime}\end{array}$ & ND & Bio89 \\
\hline 47 & 05536108 & $\begin{array}{l}\text { North Shore Channel at Devon Avenue } \\
\text { at Chicago, Ill. } \\
\text { Lat } 41^{\circ} 59^{\prime} 51^{\prime \prime} \text { Long } 87^{\circ} 42^{\prime} 38^{\prime \prime}\end{array}$ & 20.4 & VOC, Nutr \\
\hline 48 & 05536142 & $\begin{array}{l}\text { Chicago Sanitary and Ship Canal at } \\
\text { Forest View, Ill. } \\
\text { Lat } 41^{\circ} 48^{\prime} 04^{\prime \prime} \text { Long } 87^{\circ} 48^{\prime} 06^{\prime \prime}\end{array}$ & ND & VOC, Nutr \\
\hline 49 & 05536195 & $\begin{array}{l}\text { Little Calumet River at Munster, Ind. } \\
\text { Lat } 41^{\circ} 34^{\circ} 07^{\prime \prime} \text { Long } 87^{\circ} 31^{\prime} 18^{\prime \prime}\end{array}$ & 90.0 & Retro, Ifix \\
\hline 50 & 05536275 & $\begin{array}{l}\text { Thorn Creek at Thornton, Ill. } \\
\text { Lat } 41^{\circ} 34^{\prime} 05^{\prime \prime} \text { Long } 87^{\circ} 36^{\prime} 30^{\prime \prime}\end{array}$ & 104 & Retro, Ifix \\
\hline 51 & 05536290 & $\begin{array}{l}\text { Little Calumet River at South } \\
\text { Holland, Ill. } \\
\text { Lat } 41^{\circ} 36^{\prime} 25^{\prime \prime} \text { Long } 87^{\circ} 35^{\prime} 52^{\prime \prime}\end{array}$ & 208 & Nutr \\
\hline 52 & 05536325 & $\begin{array}{l}\text { Little Calumet River at Harvey, Ill. } \\
\text { Lat } 41^{\circ} 37^{\prime} 35^{\prime \prime} \text { Long } 87^{\circ} 38^{\prime} 05^{\prime \prime}\end{array}$ & 254 & VOC \\
\hline 104 & 055363252 & $\begin{array}{l}\text { Little Calumet River at Halsted Avenue } \\
\text { at Harvey, Ill. } \\
\text { Lat } 41^{\circ} 37^{\prime} 45^{\prime \prime} \text { Long } 87^{\circ} 38^{\prime} 30^{\prime \prime}\end{array}$ & 254 & Bio90, Nutr \\
\hline 53 & 05536366 & $\begin{array}{l}\text { Little Calumet River at Calumet Park, Ill. } \\
\text { Lat } 41^{\circ} 39^{\prime} 26^{\prime \prime} \text { Long } 87^{\circ} 38^{\prime} 29^{\prime \prime}\end{array}$ & 24.3 & Bio89, Bio90 \\
\hline
\end{tabular}


APPENDIX: SELECTED WATER-SAMPLING STATIONS INCLUDED IN THE WATERQUALITY ASSESSMENT OF THE UPPER ILLINOIS RIVER BASIN, 1987-92-CONTINUED

\begin{tabular}{|c|c|c|c|c|}
\hline $\begin{array}{l}\text { Map } \\
\text { reference } \\
\text { number }\end{array}$ & $\begin{array}{l}\text { Station } \\
\text { number }\end{array}$ & Station name & $\begin{array}{l}\text { Drainage area } \\
\text { (square miles) }\end{array}$ & Phase of study \\
\hline 54 & 05536700 & $\begin{array}{l}\text { Calumet-Sag Channel at Sag Bridge, Ill. } \\
\text { Lat } 41^{\circ} 41^{\prime} 45^{\prime \prime} \text { Long } 87^{\circ} 56^{\prime} 11^{\prime \prime}\end{array}$ & 389 & Retro, Ifix, Nutr \\
\hline 56 & 05537000 & $\begin{array}{l}\text { Chicago Sanitary and Ship Canal at } \\
\text { Lockport, Ill. } \\
\text { Lat } 41^{\circ} 34^{\prime} 11^{\prime \prime} \text { Long } 88^{\circ} 04^{\prime} 42^{\prime \prime}\end{array}$ & 740 & Retro, Ifix, \\
\hline 58 & 05538008 & $\begin{array}{l}\text { Des Plaines River above Brandon Road Dam } \\
\text { at Joliet, Ill. } \\
\text { Lat } 41^{\circ} 30^{\prime} 24^{\prime \prime} \text { Long } 88^{\circ} 05^{\prime} 49^{\prime \prime}\end{array}$ & 1,510 & $\begin{array}{l}\text { Bio89, Bio90, VOC, } \\
\text { Nutr }\end{array}$ \\
\hline 60 & 05539000 & $\begin{array}{l}\text { Hickory Creek at Joliet, Ill. } \\
\text { Lat } 41^{\circ} 31^{\prime} 10^{\prime \prime} \text { Long } 88^{\circ} 04^{\prime} 10^{\prime \prime}\end{array}$ & 107 & Retro, Ifix \\
\hline 61 & 05539360 & $\begin{array}{l}\text { Des Plaines River below Lock and Dam } \\
\text { at Rockdale, Ill. } \\
\text { Lat } 41^{\circ} 30^{\prime} 00^{\prime \prime} \text { Long } 88^{\circ} 06^{\prime} 12^{\prime \prime}\end{array}$ & 1,630 & Nutr \\
\hline 64 & 05540095 & $\begin{array}{l}\text { West Branch Du Page River near } \\
\text { Warrenville, Ill. } \\
\text { Lat } 41^{\circ} 49^{\prime} 22^{\prime \prime} \text { Long } 88^{\circ} 10^{\prime} 23^{\prime \prime}\end{array}$ & 90.4 & Retro, Ifix, \\
\hline 65 & 05540210 & $\begin{array}{l}\text { East Branch Du Page River at } \\
\text { Route } 34 \text { Bridge near Lisle, Ill. } \\
\text { Lat } 41^{\circ} 48^{\prime} 02^{\prime \prime} \text { Long } 88^{\circ} 04^{\prime} 53^{\prime \prime}\end{array}$ & 51.4 & Retro, Ifix, \\
\hline 66 & 05540258 & $\begin{array}{l}\text { East Branch Du Page River at } \\
\text { Naperville, Ill. } \\
\text { Lat } 41^{\circ} 42^{\prime} 52^{\prime \prime} \text { Long } 88^{\circ} 06^{\prime} 44^{\prime \prime}\end{array}$ & ND & Bio89, Bio90 \\
\hline 67 & 05540290 & $\begin{array}{l}\text { Du Page River near Naperville,Ill. } \\
\text { Lat } 41^{\circ} 41^{\prime} 24^{\prime \prime} \text { Long } 88^{\circ} 09^{\prime} 58^{\prime \prime}\end{array}$ & 220 & Retro, Ifix, VOC, Nutr \\
\hline 68 & 05540490 & $\begin{array}{l}\text { Du Page River at Hammel Woods at } \\
\text { Shorewood, Ill. } \\
\text { Lat } 41^{\circ} 31^{\prime} 54^{\prime \prime} \text { Long } 88^{\circ} 11^{\prime} 34^{\prime \prime}\end{array}$ & ND & Bio89, Bio90 \\
\hline
\end{tabular}


APPENDIX: SELECTED WATER-SAMPLING STATIONS INCLUDED IN THE WATERQUALITY ASSESSMENT OF THE UPPER ILLINOIS RIVER BASIN, 1987-92-CONTINUED

\begin{tabular}{|c|c|c|c|c|}
\hline $\begin{array}{c}\text { Map } \\
\text { reference } \\
\text { number }\end{array}$ & $\begin{array}{l}\text { Station } \\
\text { number }\end{array}$ & Station name & $\begin{array}{l}\text { Drainage area } \\
\text { (square miles) }\end{array}$ & Phase of study \\
\hline \multicolumn{5}{|c|}{ Des Plaines River Basin—Continued } \\
\hline 69 & 05540500 & $\begin{array}{l}\text { Du Page River at Shorewood, Ill. } \\
\text { Lat } 41^{\circ} 31^{\prime} 20^{\prime \prime} \text { Long } 88^{\circ} 11^{\prime} 35^{\prime \prime}\end{array}$ & 324 & Retro, Ufix, VOC, Nutr \\
\hline \multicolumn{5}{|c|}{ Illinois River Basin } \\
\hline 70 & 05541498 & $\begin{array}{l}\text { Illinois River above Dresden Island Dam } \\
\text { near Minooka, Ill. } \\
\text { Lat } 41^{\circ} 23^{\prime} 58^{\prime \prime} \text { Long } 88^{\circ} 16^{\prime} 35^{\prime \prime}\end{array}$ & ND & VOC, Nutr \\
\hline 71 & 05541508 & $\begin{array}{l}\text { Illinois River below Dresden Island Dam } \\
\text { near Minooka, Ill. } \\
\text { Lat } 41^{\circ} 23^{\prime} 51^{\prime \prime} \text { Long } 88^{\circ} 17^{\prime} 59^{\prime \prime}\end{array}$ & ${ }^{1} 7,280$ & Nutr \\
\hline 72 & 05541710 & $\begin{array}{l}\text { Aux Sable Creek near Morris, Ill. } \\
\text { Lat } 41^{\circ} 25^{\prime} 02^{\prime \prime} \text { Long } 88^{\circ} 20^{\prime} 51^{\prime \prime}\end{array}$ & 172 & Retro, Ifix, Nutr \\
\hline 73 & 05541745 & $\begin{array}{l}\text { Mazon River near Gardener, Ill. } \\
\text { Lat } 41^{\circ} 12^{\prime} 22^{\prime \prime} \text { Long } 88^{\circ} 17^{\prime} 01^{\prime \prime}\end{array}$ & ND & VOC, Nutr \\
\hline 74 & 05542000 & $\begin{array}{l}\text { Mazon River near Coal City, Ill. } \\
\text { Lat } 41^{\circ} 17^{\prime} 10^{\prime \prime} \text { Long } 88^{\circ} 21^{\prime} 35^{\prime \prime}\end{array}$ & 455 & Retro, Ifix, VOC, Nutr \\
\hline 75 & 05543484 & $\begin{array}{l}\text { Illinois River above Marseilles Dam } \\
\text { at Marseilles, Ill. } \\
\text { Lat } 41^{\circ} 19^{\prime} 19^{\prime \prime} \text { Long } 88^{\circ} 42^{\prime} 19^{\prime \prime}\end{array}$ & ND & VOC, Nutr \\
\hline 76 & 05543500 & $\begin{array}{l}\text { Illinois River at Marseilles, Ill. } \\
\text { Lat } 41^{\circ} 19^{\prime} 37^{\prime \prime} \text { Long } 88^{\circ} 43^{\prime} 03^{\prime \prime}\end{array}$ & 8,260 & $\begin{array}{c}\text { Retro, Ufix, Bio89, Bio90, } \\
\text { VOC, Nutr }\end{array}$ \\
\hline \multicolumn{5}{|c|}{ Fox River Basin } \\
\hline 77 & 05543814 & $\begin{array}{l}\text { Pewaukee River at State Route } 164 \\
\text { at Waukesha, Wis. } \\
\text { Lat } 43^{\circ} 02^{\prime} 29^{\prime \prime} \text { Long } 88^{\circ} 12^{\prime} 39^{\prime \prime}\end{array}$ & ND & Nutr \\
\hline 78 & 05544090 & $\begin{array}{l}\text { Mukwonago River at Marsh Road } \\
\text { near Mukwonago, Wis. } \\
\text { Lat } 42^{\circ} 51^{\prime} 17^{\prime \prime} \text { Long } 88^{\circ} 23^{\prime} 44^{\prime \prime}\end{array}$ & ND & Bio90, Nutr \\
\hline 79 & 05544315 & $\begin{array}{l}\text { Fox River near Big Bend, Wis. } \\
\text { Lat } 42^{\circ} 52^{\prime} 38^{\prime \prime} \text { Long } 88^{\circ} 14^{\prime} 53^{\prime \prime}\end{array}$ & ND & VOC, Nutr \\
\hline 80 & 05544908 & $\begin{array}{l}\text { Honey Creek at Bell School Road } \\
\text { near East Troy, Wis. } \\
\text { Lat } 42^{\circ} 47^{\prime} 43^{\prime \prime} \text { Long } 88^{\circ} 19^{\prime} 15^{\prime \prime}\end{array}$ & ND & Bio90, Nutr \\
\hline 81 & 05544950 & $\begin{array}{l}\text { Honey Creek at Hill Valley Road } \\
\text { near East Troy, Wis. } \\
\text { Lat } 42^{\circ} 47^{\prime} 03^{\prime \prime} \text { Long } 88^{\circ} 18^{\prime} 33^{\prime \prime}\end{array}$ & ND & Bio89 \\
\hline 82 & 05545300 & $\begin{array}{l}\text { White River near Burlington, Wis. } \\
\text { Lat } 42^{\circ} 39^{\prime} 57^{\prime \prime} \text { Long } 88^{\circ} 19^{\prime} 03^{\prime \prime}\end{array}$ & 110 & Nutr \\
\hline
\end{tabular}




\section{APPENDIX: SELECTED WATER-SAMPLING STATIONS INCLUDED IN THE WATER- QUALITY ASSESSMENT OF THE UPPER ILLINOIS RIVER BASIN, 1987-92-CONTINUED}

\begin{tabular}{|c|c|c|c|c|}
\hline $\begin{array}{l}\text { Map } \\
\text { reference } \\
\text { number }\end{array}$ & $\begin{array}{l}\text { Station } \\
\text { number }\end{array}$ & Station name & $\begin{array}{l}\text { Drainage area } \\
\text { (square miles) }\end{array}$ & Phase of study \\
\hline \multicolumn{5}{|c|}{ Fox River Basin-Continued } \\
\hline 83 & 05546500 & $\begin{array}{l}\text { Fox River at Wilmot, Wis. } \\
\text { Lat } 42^{\circ} 30^{\prime} 40^{\prime \prime} \text { Long } 88^{\circ} 10^{\prime} 45^{\prime \prime}\end{array}$ & 868 & Retro \\
\hline 84 & 05546700 & $\begin{array}{l}\text { Fox River near Channel Lake, Ill. } \\
\text { Lat } 42^{\circ} 28^{\prime} 45^{\prime \prime} \text { Long } 88^{\circ} 10^{\prime} 42^{\prime \prime}\end{array}$ & 2871 & Retro, Ifix \\
\hline 86 & 05548280 & $\begin{array}{l}\text { Nippersink Creek near Spring Grove, Ill. } \\
\text { Lat } 42^{\circ} 26^{\prime} 37^{\prime \prime} \text { Long } 88^{\circ} 14^{\prime} 51^{\prime \prime}\end{array}$ & 192 & Retro, Ifix, Nutr \\
\hline 87 & 05549500 & $\begin{array}{l}\text { Fox River near McHenry, Ill. } \\
\text { Lat } 42^{\circ} 18^{\prime} 35^{\prime \prime} \text { Long } 88^{\circ} 15^{\prime} 05^{\prime \prime}\end{array}$ & 1,250 & VOC, Nutr \\
\hline 88 & 05549600 & $\begin{array}{l}\text { Fox River at Burton's Bridge, Ill. } \\
\text { Lat } 42^{\circ} 16^{\prime} 44^{\prime \prime} \text { Long } 88^{\circ} 13^{\prime} 31^{\prime \prime}\end{array}$ & 1,280 & Retro, Ifix \\
\hline 89 & 05550000 & $\begin{array}{l}\text { Fox River at Algonquin, Ill. } \\
\text { Lat } 42^{\circ} 09^{\prime} 59^{\prime \prime} \text { Long } 88^{\circ} 17^{\prime} 25^{\prime \prime}\end{array}$ & 1,400 & $\begin{array}{c}\text { Retro, Ufix, Bio89, Bio90, } \\
\text { Nutr }\end{array}$ \\
\hline 90 & 05550500 & $\begin{array}{l}\text { Poplar Creek at Elgin, Ill. } \\
\text { Lat } 42^{\circ} 01^{\prime} 35^{\prime \prime} \text { Long } 88^{\circ} 15^{\prime} 20^{\prime \prime}\end{array}$ & 35.2 & Retro, Ifix, Nutr \\
\hline 91 & 05551000 & $\begin{array}{l}\text { Fox River at South Elgin, Ill. } \\
\text { Lat } 41^{\circ} 59^{\prime} 40^{\prime \prime} \text { Long } 88^{\circ} 17^{\prime} 38^{\prime \prime}\end{array}$ & 1,560 & Retro, Ifix, VOC, Nutr \\
\hline 92 & 05551540 & $\begin{array}{l}\text { Fox River at Montgomery, Ill. } \\
\text { Lat } 41^{\circ} 43^{\prime} 46^{\prime \prime} \text { Long } 88^{\circ} 20^{\prime} 19^{\prime \prime}\end{array}$ & 1,730 & Retro, Ifix, VOC, Nutr \\
\hline 93 & 05551700 & $\begin{array}{l}\text { Blackberry Creek near Yorkville, Ill. } \\
\text { Lat } 41^{\circ} 40^{\prime} 18^{\prime \prime} \text { Long } 88^{\circ} 26^{\prime} 29^{\prime \prime}\end{array}$ & 70.2 & Retro, Ifix, Bio90, VOC \\
\hline 94 & 05551933 & $\begin{array}{l}\text { Big Rock Creek above Henning Road } \\
\text { near Plano, Ill. } \\
\text { Lat } 41^{\circ} 41^{\prime} 58^{\prime \prime} \text { Long } 88^{\circ} 30^{\prime} 30^{\prime \prime}\end{array}$ & ND & Bio90 \\
\hline 95 & 05551937 & $\begin{array}{l}\text { Big Rock Creek at Route } 276 \text { near } \\
\text { Plano, Ill. } \\
\text { Lat } 41^{\circ} 38^{\prime} 28^{\prime \prime} \text { Long } 88^{\circ} 32^{\prime} 14^{\prime \prime}\end{array}$ & 182 & Nutr \\
\hline 96 & 05551995 & $\begin{array}{l}\text { Somonauk Creek at Sheridan, Ill. } \\
\text { Lat } 41^{\circ} 32^{\prime} 37^{\prime \prime} \text { Long } 88^{\circ} 41^{\prime} 12^{\prime \prime}\end{array}$ & 83.3 & Retro, Ifix, \\
\hline 97 & 05552200 & $\begin{array}{l}\text { Indian Creek near Harding, Ill. } \\
\text { Lat } 41^{\circ} 30^{\prime} 50^{\prime \prime} \text { Long } 88^{\circ} 47^{\prime} 50^{\prime \prime}\end{array}$ & ND & Bio89, Bio90 \\
\hline 98 & 05552400 & $\begin{array}{l}\text { Indian Creek at Route } 258 \text { at Wedron, Ill. } \\
\text { Lat } 41^{\circ} 26^{\prime} 33^{\prime \prime} \text { Long } 88^{\circ} 46^{\prime} 15^{\prime \prime}\end{array}$ & 265 & Nutr \\
\hline 99 & 05552500 & $\begin{array}{l}\text { Fox River at Dayton, Ill. } \\
\text { Lat } 41^{\circ} 23^{\prime} 12^{\prime \prime} \text { Long } 88^{\circ} 47^{\prime} 26^{\prime \prime}\end{array}$ & 2,640 & $\begin{array}{l}\text { Retro, Ufix, Bio90, VOC, } \\
\text { Nutr }\end{array}$ \\
\hline
\end{tabular}

reference

number

83

84

86

87

0

1

${ }^{1}$ Drainage area at Dresden Island Dam; Lat $41^{\circ} 23^{\prime} 53^{\prime \prime}$, Long $88^{\circ} 16^{\prime} 45^{\prime \prime}$.

${ }^{2}$ Water-discharge records for this station were from Fox River at Wilmot, Wis. 